BRUNA FERREIRA DE SOUZA

\title{
INVESTIGAÇÃO DOS mRNAs DE FUSÃO DO GENE TMPRSS2/ERG EM PACIENTES COM CÂNCER DE PRÓSTATA
}

Dissertação apresentada ao Programa de Pós-Graduação do Departamento de Genética da Faculdade de Medicina de Ribeirão Preto/Universidade de São Paulo para obtenção do Título de Mestre em Genética

\section{Ribeirão Preto}

2013 


\section{INVESTIGAÇÃO DOS mRNAs DE FUSÃO DO GENE TMPRSS2/ERG EM PACIENTES COM CÂNCER DE PRÓSTATA}

Dissertação apresentada ao Programa de Pós-Graduação do Departamento de Genética da Faculdade de Medicina de Ribeirão Preto/Universidade de São Paulo para obtenção do Título de Mestre em Genética

Área de Concentração:
Genética Molecular

Orientador:

Victor Evangelista de Faria Ferraz

\section{Ribeirão Preto}


Autorizo a reprodução e divulgação total ou parcial deste trabalho, por qualquer meio convencional ou eletrônico, para fins de estudo e pesquisa, desde que citada a fonte.

Souza, Bruna Ferreira de

Investigação dos mRNAs de Fusão do gene TMPRSS2/ERG em pacientes com câncer de próstata. Ribeirão Preto, 2013.

95 p.: il. ; $30 \mathrm{~cm}$

Dissertação de Mestrado, apresentada à Faculdade de Medicina de Ribeirão Preto/USP. Área de concentração: Genética.

Orientador: Ferraz, Victor Evangelista de Faria.

1. TMPRSS2/ERG. 2. Rearranjos gênicos. 3. Câncer de Próstata. 4. Gene de fusão. 5. mRNAs de fusão. 
Aos meus pais, Fátima e José

Antônio e a meu namorado Samuel pelo apoio e incentivo constantes. 
AGRADECIMENTOS 


\section{AGRADECIMENTOS}

Ao Dr. Victor Evangelista de Faria Ferraz por ter sido meu orientador e amigo. Obrigado pelo respeito e principalmente pela paciência, por acreditar no meu potencial, contagiando-me com o seu incentivo. Sua serenidade e cumplicidade foram fundamentais. Obrigado por entender meus receios, me apoiando, e por me dar a oportunidade de desenvolver este trabalho.

Ao Dr. Wilson da Silva Araújo por me acolher como parte de seu grupo de maneira acolhedora e por sempre se dispor a atender minhas requisições em apoio integral. Obrigado por acreditar em mim e por me proporcionar um espaço e condições primordiais para a realização desse estudo.

Ao Dr. Luís Fernando Tirapelli pela receptividade em seu laboratório, por sua gentileza em disponibilizar seus funcionários e por prover todas as informações necessárias para a utilização e manejo do Banco de Tumores Urogenitais do HCFMRP.

Ao professor Dr. Fabiano Pinto Saggioro, responsável pelas microdissecções, sempre muito solícito. Sem dúvida seus préstimos foram fundamentais para que esse projeto se tornasse uma realidade.

Ao Dr. Rodolfo dos Reis por autorizar a utilização das amostras armazenadas no Banco de Tumores Urogenitais do HCFMRP.

À Anne por dividir comigo seu cantinho do laboratório e tantos ensinamentos, pelo admirável carinho e paciência que tanto confortam. Minha profunda admiração, sem dúvida um dos maiores exemplos de ser humano, amável, dedicada, acessível, um espelho de profissional e pessoa, ofereço-a minha gratidão.

À Dr ${ }^{\mathrm{a}}$. Greice Molfetta por abrir o caminho ao dar início a esse projeto e por ser àquela a quem contar. Obrigada pela amizade, pelos ensinamentos e pela paciência, obrigada por tudo.

À Cristiane Aires por prover apoio físico e profissional tantas vezes requisitado. Obrigada pela amizade, por sempre nos conduzir no laboratório e minha admiração por sua experiência e dedicação profissional.

Agradeço à Adriana pelas caronas tão gentis e pela agradável companhia. Sem seus sequenciamentos certamente esse trabalho não teria sido concluído.

Ao Dr. Daniel Oliveira Vidal que gentilmente dividiu comigo sua sabedoria, auxiliando em pontos chaves desse projeto e que tive a oportunidade de conhecer melhor e de dividir bancada, certamente um exemplo para os jovens pesquisadores.

Ao Paulo pela paciência, sempre disposto a colaborar, gentil e atencioso. 
À Deise, técnica responsável pelas microdissecções e um ombro amigo em momentos difíceis.

Aos meus queridos amigos de bancada (LGMB) e de tantos momentos, seria injusto inúmerá-los, afinal foram muitos, alguns foram anos, outros alguns momentos, mas carrego em mim as experiências trocadas, as boas gargalhadas, enfim tudo o que foi bom. Obrigada por compartilharem comigo tudo isso.

Aos amigos Nathália Moreno, Daniel Fantozzi e ao Willys, que desde o começo estiveram comigo nesse caminho, amigos que vou levar para sempre. E também àquelas que chegaram depois e trouxeram tanta alegria, Luiza, Bruninha, Viviane e Karina, obrigada minhas queridas, sem palavras para as infinitas boas gargalhadas proporcionadas. Em especial, obrigada Mariana minha companheira de bancada e de lar, uma amiga maravilhosa.

Aos funcionários e colegas do Departamento de Genética por toda companhia, apoio e amizade.

Aos professores do Programa de Pós-Graduação do Departamento de Genética por contribuírem para a minha formação.

Aos funcionários da Secretária do Programa de Pós-Graduação do Departamento de Genética pela atenção e carinho.

À Capes pelo apoio financeiro.

Aos meus familiares e ao meu namorado pelo incansável e reconfortante apoio em todos os momentos.

A todas as pessoas, que estiveram presentes em minha vida, sejam de perto ou de longe e que sempre torceram por mim, me incentivando, me oferecendo palavras sábias e de amizade para que tudo se tornasse mais fácil, o meu muito obrigado. 
"Agir, eis a inteligência verdadeira. Serei o que quiser. Mas tenho que querer o que for. O êxito está em ter êxito, e não em ter condições de êxito". ("Bernardo Soares" - Fernando Pessoa) 
Esta dissertação está de acordo com:

Referências: adaptado de International Committe of Medical Journals Editors (Vancouver).

Abreviaturas dos títulos dos periódicos de acordo com List of Journals Indexed in Index Medicus, disponível no site: http://www.nlm.nih.gov/tsd/serials/lji.html.

A ortografia foi revisada de acordo com o dicionário ortográfico de língua portuguesa através do site: www.academia.org.br. 


\section{RESUMO}

SOUZA, B.F. INVESTIGAÇÃO DOS mRNAS DE FUSÃO DO GENE TMPRSS2/ERG EM PACIENTES COM CÂNCER DE PRÓSTATA. 2013. Dissertação (Mestrado em Genética), Ribeirão Preto-SP: Departamento de Genética do Hospital das Clínicas de Ribeirão Preto/Universidade de São Paulo.

O interesse científico em rearranjos gênicos relacionados com a etiogênese e progressão do câncer relaciona-se, principalmente, à descoberta da fusão $B C R / A B L$ na Leucemia Mieloide Crônica, sendo que desde então, houve uma evolução no manejo dessa doença, instigando uma série de estudos correlatos em outras neoplasias. Essas pesquisas culminaram no encontro do primeiro rearranjo gênico em tumores sólidos, o gene de fusão TMPRSS2/ERG, envolvendo a região promotora do gene da serina protease, o TMPRSS2, e o gene da família de fatores de transcrição ETS, o ERG. Ele é específico de adenocarcinoma da próstata, o que o torna forte candidato a biomarcador e já demonstra exercer papel de destaque no manejo clínico do câncer de próstata $(\mathrm{CaP})$, tal qual o exercido pela fusão $B C R / A B L$. Sua frequência têm se mostrado associada a diversos fatores, sobretudo à etnia de origem. Indivíduos portadores de $\mathrm{CaP}$ oriundos de diversos países já foram estudados quanto à frequência dessa fusão e o resultado é bastante diversificado. No Brasil, entretanto, ainda não há dados a respeito desse rearranjo, e este trabalho visa contribuir para a identificação da frequência da mesma e sua contribuição para o diagnóstico e o tratamento do CaP no país. Para tal, utilizamos mRNA de 20 indivíduos com $\mathrm{CaP}$ provenientes do serviço de atendimento do HCFMRP/USP, e por meio da técnica de RT-PCR, obtivemos o cDNA dos mesmos que foram investigados quanto à presença da fusão TMPRSS2/ERG, e as amostras positivas sequenciadas para determinação do tipo de isoforma envolvida. Identificamos que $35 \%$ das amostras continham o rearranjo e que todas correspondiam à isoforma do tipo III, cuja literatura a relaciona com um fenótipo agressivo do CaP, porém não metástico, e é também a mais comumente identificada. Ao confrontarmos essa evidência com os dados clínicos e histopatológicos, constatamos que havia correlação entre eles, sugerindo assim, como em outros trabalhos, o potencial desse rearranjo como marcador de agressividade do CaP. No entanto, não verificamos relação entre a presença da fusão e dados de progressão da doença. Em vista desses resultados, destacamos a necessidade da promoção de outros trabalhos de mesmo caráter, abrangendo outras regiões, a fim de se delinear um perfil mais representativo desse rearranjo no Brasil, uma vez que seu potencial como biomarcador diagnóstico e clínico é enorme e pode influenciar sobremaneira no manejo do CaP.

Palavras-chave: TMPRSS2/ERG, rearranjos gênicos, câncer de próstata, gene de fusão, mRNAs de fusão. 


\begin{abstract}
SOUZA, BF. INVESTIGATION OF mRNAS OF THE FUSION GENE TMPRSS2/ERG IN PATIENTS WITH PROSTATE CANCER IN BRAZIL. 2013. Dissertation (Masters in Genetics) Ribeirão Preto-SP, Departamento de Genética do Hospital das Clínicas de Ribeirão Preto/Universidade de São Paulo.

Scientific interest in gene rearrangements associated with cancer progression and etiogenesis relates mainly to the discovery of $B C R / A B L$ fusion in chronic myelogenous leukemia, and since then there has been an evolution in the management of this disease, prompting a series of related studies in other malignancies. These researches resulted in the meeting of the first gene rearrangement in solid tumors, the fusion gene TMPRSS2/ERG involving the promoter region of the gene of serine protease, TMPRSS2, and the gene family of transcription factors ETS, the ERG. It is specific for adenocarcinoma of the prostate, which makes it a strong candidate biomarker and shows already exert a prominent role in the clinical management of prostate cancer ( $\mathrm{PCa})$, as is exercised by the $B C R / A B L$. Its frequency has been shown to be associated with several factors, especially the ethnic origin. Individuals with $\mathrm{CaP}$ from different countries have been studied in the frequency of this merger and the result is quite diverse. In Brazil, however, there is no data about this rearrangement, and this paper aims to contribute to the identification of the same frequency and its contribution to the diagnosis and treatment of PCa in the country. Therefore, we used mRNA from 20 individuals with $\mathrm{CaP}$ from the answering service HCFMRP/USP, and by RT-PCR, cDNA obtained from the same people who were investigated for the presence of fusion TMPRSS2/ERG, and positive samples sequenced to determine the type of isoform involved. We found that $35 \%$ of the samples contained the rearrangement and that all corresponded to the type III isoform, whose literature relates to an aggressive phenotype of $\mathrm{PCa}$, but not metastatic, and is also the most commonly identified. When we compared this evidence with clinical and histopathological data, we found that there was a correlation between them, suggesting, as in other studies, the potential of this rearrangement as a agressivity marker of PCa. However, no significant association between the presence of data fusion and disease progression. In view of these results, we highlight the need to promote other works of the same character, covering other regions, in order to delineate a more representative profile of this rearrangement in Brazil, since its potential as a biomarker and clinical diagnosis is huge and can influence greatly in the management of PCa.
\end{abstract}

Keywords: TMPRSS2/ERG, gene rearrangements, prostate cancer, fusion gene, fusion mRNAs. 


\section{LISTA DE FIGURAS}

Figura 1: Corte sagital da pelve masculina, em evidência a próstata. Adaptada de NETTER F.H., 2000.

Figura 2: Zonas da próstata. Adaptado de CRAWFORD E.D., 2009.

Figura 3: Histologia de uma glândula prostática. Adaptado de TOMULEASA C. et al., 2010 .

Figura 4: Ajuste da incidência do câncer de próstata por idade, entre diferentes raças/etnias de populações masculinas nos Estados Unidos (2001-2005).

Figura 5: Modelo de rearranjo gênico TMPRSS2/ERG por padrões de hibridização fluorescente in situ (FISH) observados no CaP. Adaptada de MACKINNON A.C. et al., 2009.

Figura 6: Esquema adaptado de WANG et al. (2006), mostrando as isoformas dos mRNAs do rearranjo TMPRSS2/ERG no CaP

Figura 7: Gel de agarose a 1,2\% mostrando o perfil eletroforético do RNA total extraído.

Figura 8: Gel de agarose 1,2\% TAE, mostrando o resultado da amplificação pela PCR para o rearranjo TMPRSS2/ERG.

Figura 9: Esquema ilustrando a estrutura da isoforma do tipo III do rearranjo $T M P R S S / E R G$ a partir do sequenciamento. 


\section{LISTA DE TABELAS}

Tabela 1: Relação do histórico familiar e o risco de CaP. Adaptada de KRALA M. et al., 2011 e dados de BRATT O., 2002.

Tabela 2: Classificação Tumor Nodo Metástase (TNM) para câncer de próstata. Tabela adaptada de PETTUS et al., 2008.

Tabela 3: Procedimentos de coloração das amostras para microdissecção.

Tabela 4: Relação dos reagentes utilizados na reação de RT-PCR e as suas respectivas quantidades utilizadas para a realização de uma reação.

Tabela 5: Oligonucleotídeos iniciadores (Foward - F e Reverse $-\mathrm{R}$ ) do gene da $\beta$ actina.

Tabela 6: Relação dos reagentes utilizados na reação de PCR para amplificação do gene da $\beta$-actina e as suas respectivas quantidades utilizadas para a realização de uma reação.

Tabela 7: Oligonucleotídeos iniciadores (F e R) do rearranjo TMPRSS2/RG.

Tabela 8: Relação dos reagentes utilizados na reação de PCR para amplificação do gene da $\beta$-actina e as suas respectivas quantidades utilizadas para a realização de uma reação.

Tabela 9: Relação dos reagentes utilizados na reação de PCR para verificação da qualidade do cDNA do gene de fusão TMPRSS2/ERG enviadas ao sequenciamento do cDNA do gene de fusão TMPRSS2/ERG e as suas respectivas quantidades utilizadas para a realização de 1 reação.

Tabela 10: Relação dos reagentes para a reação de sequenciamento do cDNA do gene de fusão TMPRSS2/ERG.

Tabela 11: Pesagem dos fragmentos de tumor da próstata microdissecados.

Tabela 12: Relação entre os pacientes e a concentração de RNA presente em suas respectivas amostras de tumor.

Tabela 13: Identificação dos 20 pacientes em estudo, registro HCFMRP-USP, idade no momento de submissão à prostatectomia radical, grau de Gleason e comprometimento da próstata pelo tumor. 
Tabela 14 - Relação entre as amostras portadorass e não portadoras do rearranjo TMPRSS2/ERG com o seu respectivo Grau de Gleason.

Tabela 15: Seguimento clínico e molecular dos pacientes após a prostatectomia radical: recorrência de PSA, presença do rearranjo TMPRSS2/ERG, metástase, invasão de vesícula seminal (VS) e estadiamento 


\section{LISTA DE ABREVIATURAS}

5AR- $5 \alpha$-redutase

ACS- Sociedade Americana do Câncer

ANXA3- Anexina A3

AR- Receptor de Andrógeno

CaP- Câncer de Próstata

cDNA- DNA complementar

CSCs- Células-Tronco Tumorais

CK- Citoqueratinas

DEPC- Dietilpirocarbonato

DHT- Dihidrotestosterona

DNA - Ácido Desóxiribonucléico

dNTPs- Desóxiribonucleotídeos

EDTA- Ácido Etilenodiamino Tetra-Cético

ER- Exame retal (

FISH- Hibridização por Fluorescência in situ

GG- Grau de Gleason

GSTP1- Glutationa-S-Transferase P

HCFMRP-USP- Hospital das Clínicas da Faculdade de Medicina de Ribeirão Preto da Universidade de São Paulo

HIF-1- Hypoxia Inducible fator 1- Fator de Indução à Hipóxia 1

INCA- Instituto Nacional do Câncer

mRNA- RNA mensageiro

NE- Células neuroendócrinas

nm- Nanômetro

PAP- Fosfatase ácida prostática

pb- Pares de Base 
PCR- Reação de Amplificação da Cadeia da Polimerase

PIN- Neoplasia Intra-Epitelial Prostática

PSA- Antígeno Prostático Específico

RNA- Ácido Ribonucleotídico

rpm - Rotações por Minuto

RT-PCR- Transcrição Reversa por meio da Reação em Cadeia da Polimerase

TAE-Tampão Tris-Acetato-EDTA

TNM- T- extensão do tumor primário, $\mathrm{N}$ - a ausência ou presença e a extensão de metástase em linfonodos regionais, M- a ausência ou presença de metástase à distância USTR- Ultra-Sonografia Transretal da Próstata

VS- Vesícula seminal

ZC- Zona Central

ZP- Zona Periférica

ZT- Zona de Transição 


\section{SUMÁRIO}

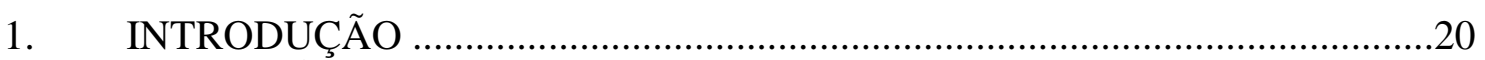

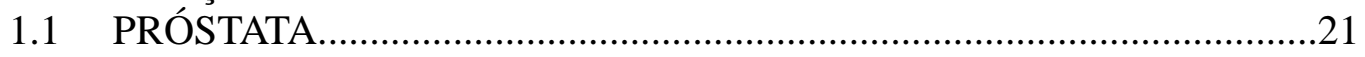

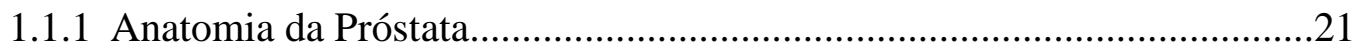

1.1.2 Fisiologia da próstata....................................................................23

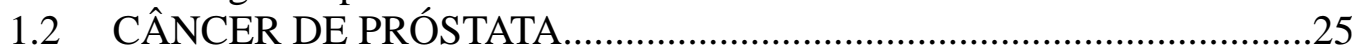

1.2.1 Epidemiologia do Câncer de Próstata $(\mathrm{CaP})$...........................................24

1.2.2 Etiogênese e evolução do CaP.............................................................25

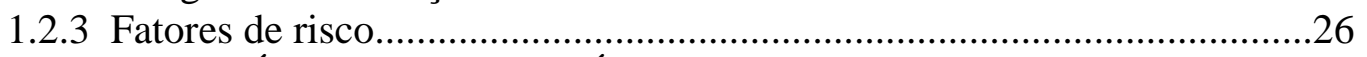

1.2.4 DIAGNÓSTICO E PROGNÓSTICO DO CaP........................................30

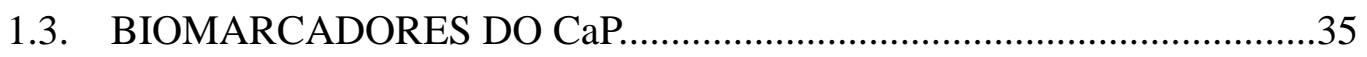

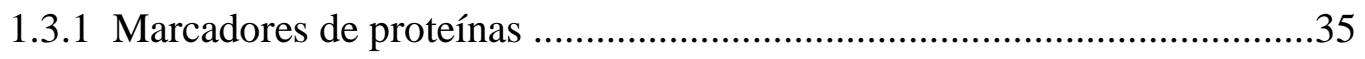

a. Antígeno Prostático Específico (PSA)....................................................35

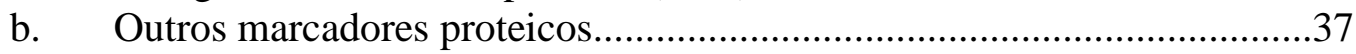

1.3.2 Biomarcadores de DNA1.4.3 Marcadores de RNA.................................37

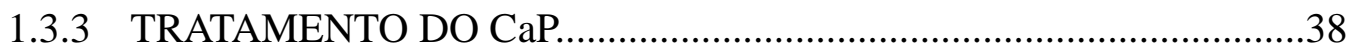

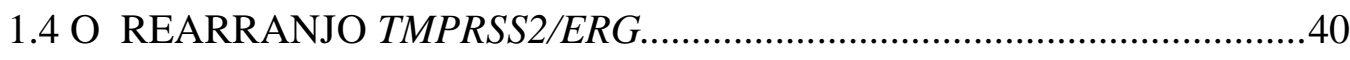

2 OBJETIVOS

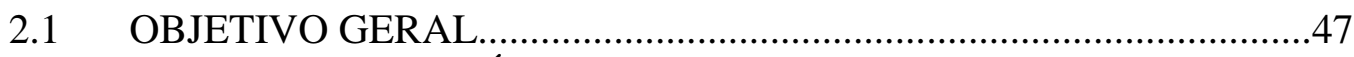

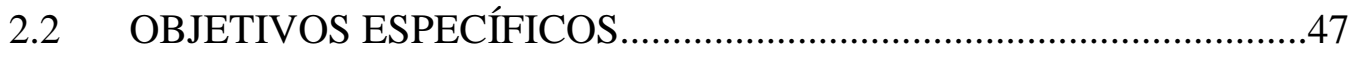

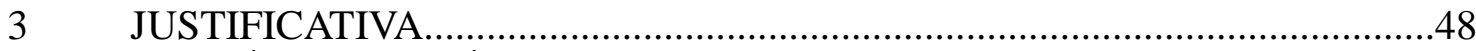

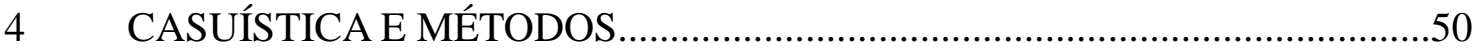

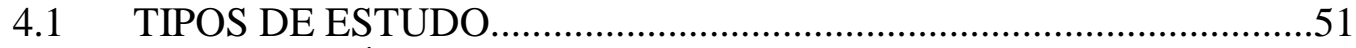

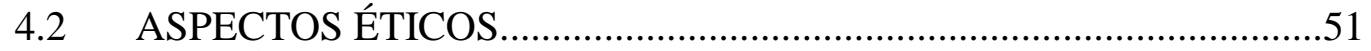

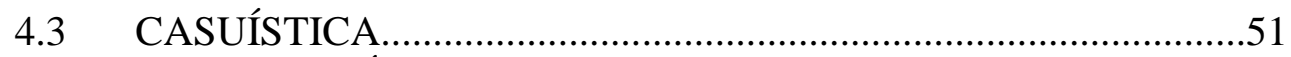

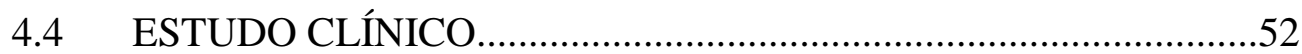

4.5 ESTUDO MOLECULAR

4.6 PREPARAÇÃO DAS AMOSTRAS DE TECIDO PROSTÁTICO PARA

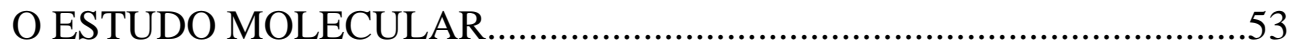

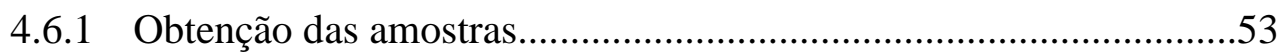

4.6.2 Microdissecção (MC) das amostras..............................................53

4.6.2.1 Processamento histológico do material............................................53

4.6.2.2 Preparo das lâminas para MC........................................................53

4.6.2.3 Microdissecção............................................................................54

4.7 ESTUDO MOLECULAR- ANÁLISE DA EXPRESSÃO GÊNICA RELATIVA

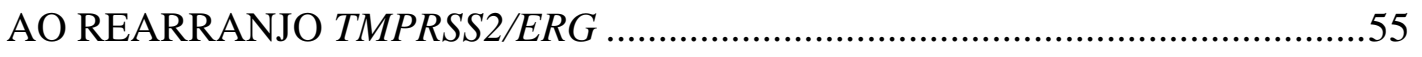

4.7.1 Peso das amostras......................................................................55

4.7.2 Cálculo da quantidade de Trizol e Glicogênio.....................................55

4.7.3 Extração de RNA total.................................................................55

a. Maceração do tecido prostático.......................................................56

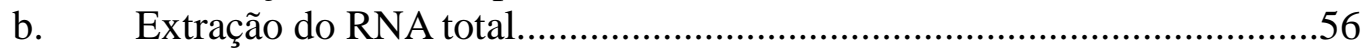

4.7.4 Determinação da qualidade do RNA.................................................57

4.7.5 Transcrição reversa (RT-PCR)..........................................................57

4.7.6 Reação em cadeia da polimerase (PCR) para amplificação do rearranjo

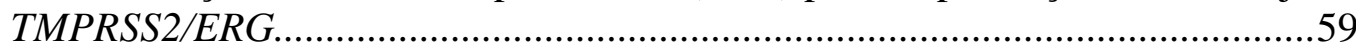

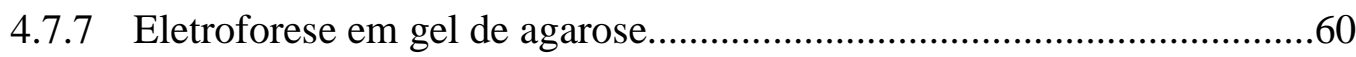

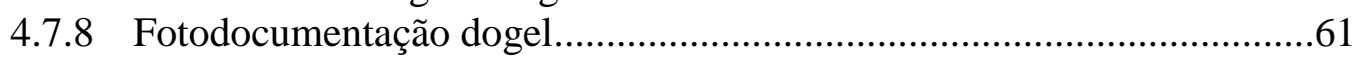


4.7.9 Reação de PCR para verificação da qualidade das amostras enviadas ao

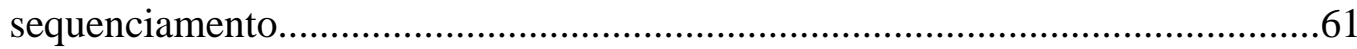

4.7.10 Quantificação do produto de PCR enviado para

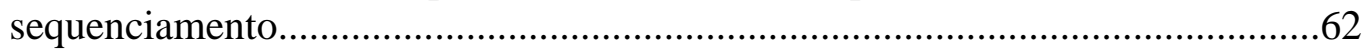

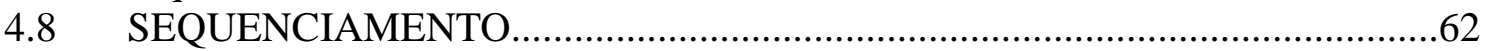

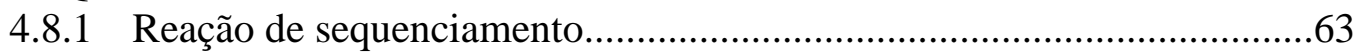

4.8.2 Precipitação............................................................................63

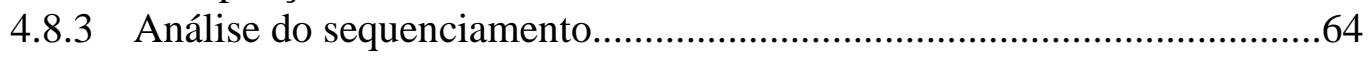

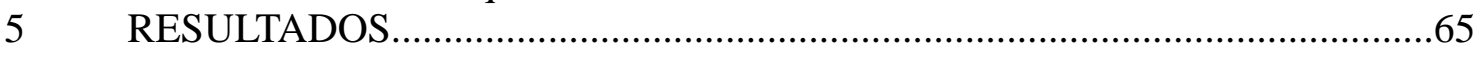

5.1 Análise molecular das

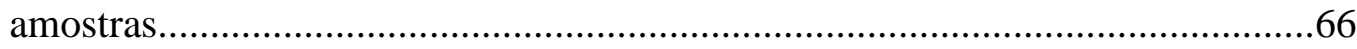

5.1.1 Microdissecção das amostras..........................................................66

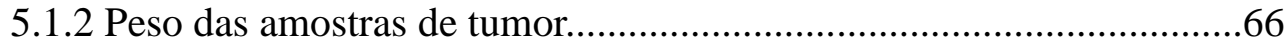

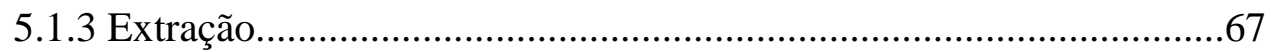

5.1.4 Verificação da qualidade das amostras.............................................67

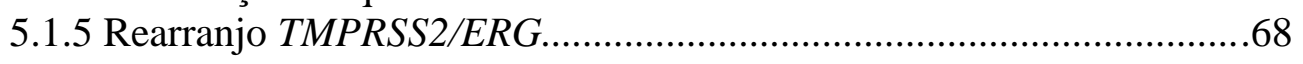

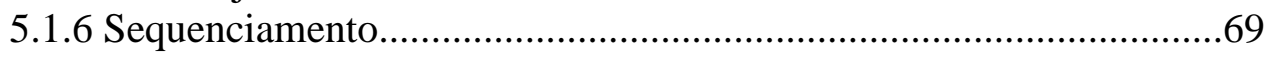

5.2 Análise clínica (Prontuário médico).....................................................71

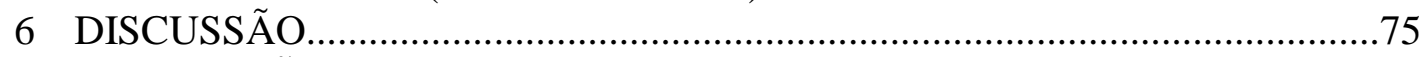

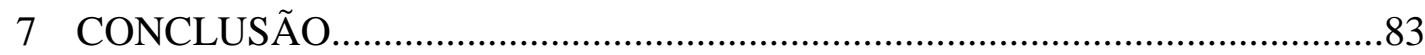

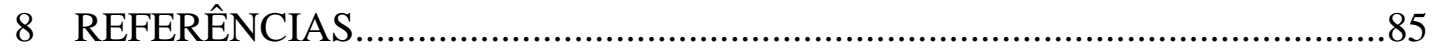




\section{INTRODUÇÃO}




\section{INTRODUÇÃO}

\subsection{PRÓSTATA}

\subsubsection{Anatomia da Próstata}

A próstata está relacionada inferiormente com a bexiga, posteriormente com a uretra e o reto, lateralmente com as fibras anteriores do músculo levantador do ânus e envolve parte da uretra (Figura 1). Em homens adultos, a próstata normal possui cerca de três centímetros de comprimento, quatro centímetros de largura e dois centímetros de profundidade, é a maior glândula acessória do sistema reprodutivo masculino. Pesa cerca de vinte gramas, podendo ser sentida através do toque retal. A parte glandular corresponde a aproximadamente dois terços da próstata, o outro terço é fibromuscular (AMÜLLER G., 1979 e MOORE K.L. \& DALLEY A.F., 2011). A cápsula fibrosa da próstata é densa e neurovascular, incorporando os plexos prostáticos de veias e nervos. Ela é ainda envolvida pela lâmina visceral da fáscia da pelve, formando a bainha prostática (MOORE K.L. \& DALLEY A.F., 2011).

Figura 1 - Corte sagital da pelve masculina, evidenciando a próstata. Adaptada de NETTER F.H., 2000.

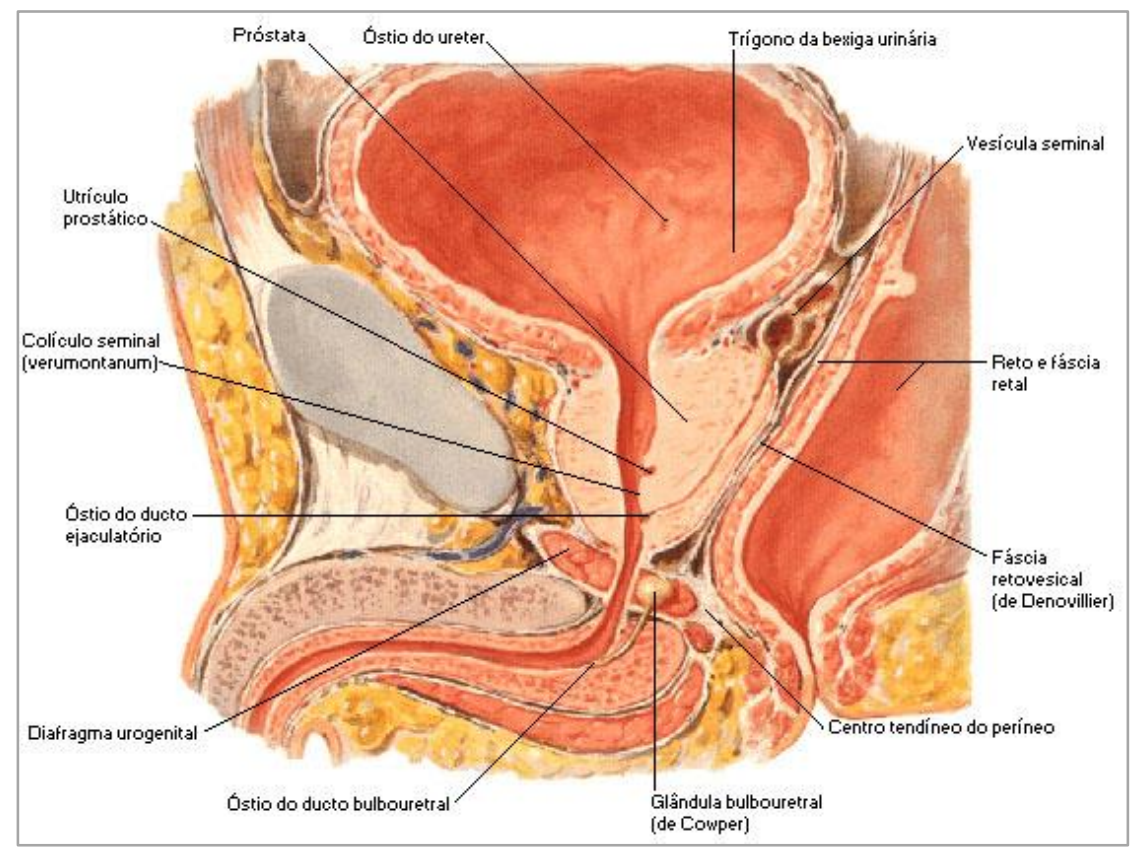


A próstata pode ser dividida em lobos, embora eles não sejam claramente distintos do ponto de vista anatômico:

- Lobo ínfero-posterior (posterior): posterior à uretra e inferiormente aos ductos ejaculatórios.

- Lobos direito e esquerdo (laterais): de cada lado da uretra, formam a parte principal da próstata.

- Lobo médio (mediano): está entre a uretra e os ductos ejaculatórios, e está relacionado com o colo da bexiga.

Há, ainda, o istmo da próstata que é fibromuscular e anterior à uretra, que contém pouco ou nenhum tecido glandular (McNEAL J.E., 1981). Há urologistas e ultra-sonografistas que dividem a próstata em zonas (Figura 2): periférica (ZP), central (ZC) e de transição (ZT), que correspondem a respectivamente $75 \%, 20 \%$ e $5 \%$ de toda a próstata. A zona central é comparável ao lobo médio (McNEAL J.E., 1981;De MARZO et al., 2003 e JOSHUA A.M. et al., 2008).

Figura 2-Zonas da próstata. Adaptado de CRAWFORD E.D., 2009.

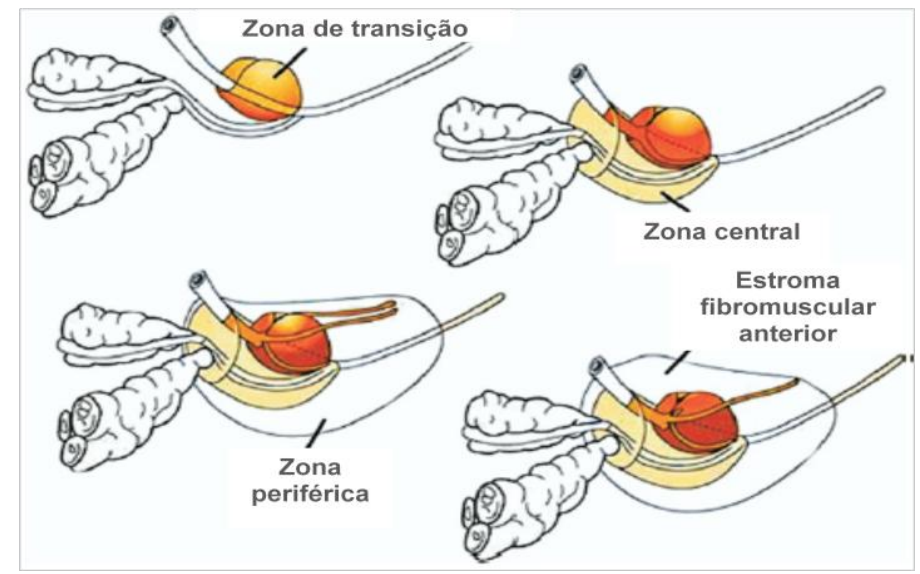

\subsubsection{Fisiologia da próstata}

A próstata é um órgão do sistema reprodutor masculino cuja principal função é armazenar e secretar um fluido alcalino ( $\mathrm{pH}$ : 7,29) de coloração clara, que constitui de 10 a $30 \%$ do volume do fluido seminal, que irá constituir juntamente com os espermatozoides, o sêmen. Esse fluido contém elementos essenciais para o funcionamento do espermatozoide, como a fosfatase ácida, o ácido cítrico e o zinco, 
além de enzimas proteolíticas e antígeno próstático específico (PSA). Ele também contém grandes quantidades de poliaminas que regulam o $\mathrm{pH}$ do esperma e preservam um ambiente ligeiramente alcalino, o que o permite neutralizar a acidez do trato vaginal, prolongando o tempo de vida dos espermatozoides (STEIVE H., 1930 \& AMÜLLER G., 1979 e DEVENS B.H. et al., 2000).

Na próstata, a testosterona é convertida para di-hidrotestosterona (DHT) nas células estromais, e nas basais prostáticas pela $5 \alpha$-redutase (5AR).O DHT é o principal andrógeno da próstata e desempenha um papel essencial no seu crescimento e desenvolvimento (ZHU Y.S. \& SUN G.H., 2005). O DHT tem 10 vezes mais afinidade para o receptor de andrógeno (AR) do que a testosterona (WILBERT D.M. et al., 1983), sendo que a administração de DHT pode aumentar o volume da próstata (IMPERATOMcGINLEY J. \& ZHU Y.S., 2002).

O epitélio prostático contém três distintas populações de células epiteliais: células secretoras luminais, basais e células neuroendócrinas (NE) (Figura 3). As células luminais expressam o PSA, uma fosfatase ácida prostática (PAP), o AR, uma citoqueratinas (CK) 8 e 18. As células basais estão localizadas logo abaixo da camada luminal e expressam CK5 e CK14 e demonstraram ser o nicho das células-tronco da próstata, porém, essas células expressam baixos níveis de AR e nenhum PSA ou PAP (ABATE-SHEN C. \& SHEN M.M, 2000 e LAWSON D.A. \& WITTE O.N., 2007). As células NE são quiescentes e expressam marcadores específicos como a cromogramina A e não expressam AR ou PSA (PALAPATTU G.S. et al., 2009).

Figura 3- Histologia da glândula prostática. Adaptado de TOMULEASA C. et al., 2010

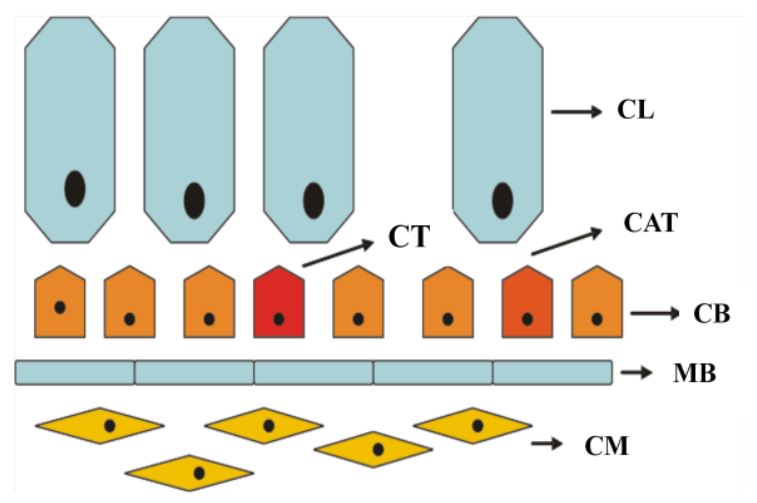

(CL) - Célula luminal

(CT) - Células tronco

(CAT)- Células de amplificação de transição

(CB) - Células basais

(MB) - Membrana basal

(CM) - Células mesenquimais

\subsection{CÂNCER DE PRÓSTATA}




\subsubsection{EPIDEMIOLOGIA DO CÂNCER DE PRÓSTATA (CaP)}

O Câncer de Próstata $(\mathrm{CaP})$ é um dos tumores sólidos mais graves e de maior incidência no sexo masculino. Segundo dados disponíveis até o momento, o CaP é considerado a segunda maior causa de mortes por câncer em todo mundo, sendo que cerca de 915 mil novos casos foram identificados no ano de 2008 (JEMAL A. et al., 2008). Aproximadamente um quarto desses casos foi verificado em países desenvolvidos, atribuindo-se às práticas de rastreamento pelo teste Antígeno Prostático Específico (PSA). A taxa de incidência mundial cresceu cerca de 25 vezes, sendo as mais altas observadas na Austrália, Nova Zelândia, Europa Ocidental e América do Norte, segundo dados do Instituto Nacional do Câncer (INCA, 2012).

No Brasil o CaP é a quarta causa de morte por neoplasias, correspondendo a $6 \%$ do total de óbitos por este grupo nosológico (INCA, 2002). Para o ano de 2012, estimam-se 60.180 novos casos de CaP tenham surgido no país. Nas regiões Sudeste (78/100 mil) e Nordeste (43/100 mil) do país o CaP é o mais incidente entre os homens. Sem considerar os tumores da pele não melanoma, é o mais frequente nas regiões Centro-Oeste (75/100 mil), Sul (68/100 mil) e Norte (30/100 mil). Portanto, entre os homens ele será o segundo mais incidente em 2012, correspondendo a 30,8\% de todos os tipos de câncer que podem vir a acometer o sexo masculino no país. A explicação para esse aumento das taxas de incidência ao longo dos anos é atribuída ao aumento da expectativa de vida, a melhoria e evolução tanto dos métodos diagnósticos, quanto dos sistemas de informação do país (INCA, 2012).

Uma das características mais marcantes do câncer de próstata é a sua prevalência. Estudos de autópsias indicam que em média um em cada três homens com idade superior a 50 anos apresentam evidências histológicas de alterações neoplásicas na próstata. Entretanto, a grande maioria desses casos é latente, sem progresso clínico importante (YATANI R. et al., 1982 e IMAIDA K., et al. 1997).

O índice de mortalidade dessa neoplasia é ascendente, porém de magnitude menor do que o índice verificado para a sua incidência. Isso se deve, principalmente, porque o $\mathrm{CaP}$ é considerado um câncer de bom prognóstico se diagnosticado e tratado oportunamente. Os programas de controle da doença também contribuem para a redução da mortalidade, porém em menor escala, pois, os métodos de rastreamentos atuais, 
como o PSA, não mostraram, até o momento, sucesso completo na redução da mortalidade (INCA, 2012).

\subsubsection{ETIOGÊNESE E EVOLUÇÃO DO CaP}

A inflamação é uma ocorrência comum na próstata e vem sendo apontada como o primeiro evento etiológico do câncer de próstata $(\mathrm{CaP})$. A origem desses infiltrados inflamatórios pode estar vinculada a exposição a agentes infecciosos ou químicos e é clinicamente denominada de prostatite (ELKAHWAJ J.E. et al., 2006). Posterior à inflamação, há uma atrofia desses infiltrados e as células epiteliais aumentam a expressão do marcador de proliferação Ki-67 (ZIPORI D. et al., 2004). Essa proliferação aumenta o tamanho da próstata, o que pode comprimir a uretra dificultando a passagem da urina, quadro denominado de hiperplasia prostática. Além disso, as células inflamatórias e mediadores podem desestabilizar o genoma das células, danificando o DNA ou afetando os checkpoints e os sistemas de reparo (COLLOTA F. et al., 2009). A instabilidade genética implantada, condicionada a aceleradas divisões somáticas, resultam em uma população genomicamente heterogênea, quanto a sua capacidade proliferativa, metastática e de evasão do sistema imune, caracterizando o CaP (TOMULEASA C. et al., 2010).

Quase todos os casos de CaP são adenocarcinomas (MILLER G.J. \&TORKKO K.C., 2001). Cerca de 4\% dos CaP exibem morfologia celular transicional e provavelmente se desenvolveram de uma linhagem urogenital da uretra prostática e, poucos casos possuem origem neuroendócrina (THEODORESCU D., 2001). A maioria dos CaPs, cerca de 70\%, iniciam na zona periférica, o restante, cerca de 10-15\%, na zona de transição e 15-20\% na zona central (McNEAL J.E., 1981; SHAIKHIBRAHIM, Z. et al., 2012). Entretanto, em sua evolução a maioria dos casos é multifocal (múltiplos clones malignos independentes estão presentes na mesma glândula), e tipicamente apresentam diferentes estádios. Isso confere ao tumor uma característica heterogênea, o que dificulta a caracterização do carcinoma na biópsia, uma vez que esta representa apenas uma porção ínfima de toda a próstata. Uma análise mais fidedigna pode ser feita após a remoção completa da próstata (MILLER G.J. \&TORKKO K.C., 2001).

Estudos apontam a hipótese de que a camada luminal da glândula prostática é o sítio de origem das células-tronco tumorais (CSCs- cancer stem cells) do CaP 
(ENGLISH H.F. et al., 1987 e LAWSON D.A. \& WITTE O.N., 2007), o que têm sido sustentado por outros estudos que demonstraram que essas células expressam muitas moléculas reguladoras do mecanismo de auto renovação e sobrevivência das CSCs, tais como p63, hTERT e Bcl-2, além de marcadores de CSCs do CaP, como CD44, CD49f, CD117, CD133, terc e p63 (LIU A.Y.et al., 1997 e TANG D.G. et al., 2007). Outra evidência é o encontro da expressão dos transcritos do gene de fusão TMPRSS2-ERG em células CD44 presentes na camada luminal (MAITLAND N.J. et al., 2011). Porém, a origem das CSCs do CaP e o tipo de célula de origem ainda é controverso, visto a grande heterogeneidade dessa neoplasia. É plausível que diferentes CaPs são derivados de diferentes tipos de células de origem (YU C. et al., 2012).

O adenocarcinoma da próstata geralmente evolui através de uma série de fases definidas: a partir de uma neoplasia intra-epitelial prostática (PIN), progride para o $\mathrm{CaP}$ localizado, posteriormente torna-se invasivo e, eventualmente, culmina em câncer metastático. As células tumorais são geralmente $\mathrm{AR}+\mathrm{e} P S A+e$, inicialmente, respondem à depleção androgênica. Depois de uma remissão, de até vários anos, o CaP pode vir a se tornar resistente à terapia e, eventualmente, progride apesar dos baixos níveis de andrógenos e sob efeito de quimioradioterapia (SKARIN A.T., 2010).

Outra consideração importante sobre a gênese dessa neoplasia é a influência do microambiente do tecido prostático sobre o comportamento das células tumorais e sua capacidade metastática. No câncer, as interações célula-célula e célula-matriz estão sobrepostas a outras características da fisiopatologia do microambiente tumoral, como o pH, hipóxia e privação de nutrientes. Alterações nestes parâmetros influenciam o potencial neurogênico e pró-angiogênico das CSCs (HILL R.P. et al., 2009). Muitos genes são transcricionalmente regulados por hipóxia e pelo fator de indução à hipóxia 1 (HIF-1- hypoxiainduciblefator 1) (DAS B. et al., 2008). Como o CaP é heterogêneo, há diferentes microambientes, e por conseguinte, diversas manifestações dessa neoplasia na próstata de um mesmo indivíduo.

\subsubsection{FATORES DE RISCO}

O único fator de risco bem estabelecido para o desenvolvimento do câncer de próstata é a idade, já que tanto a incidência quanto a mortalidade aumentam exponencialmente após os 50 anos de idade (INCA, 2002). Aproximadamente $62 \%$ dos 
casos dos CaPs diagnosticados no mundo acometem homens com 65 anos ou mais. Com o crescimento da expectativa de vida mundial, é esperado que o número de casos novos aumente cerca de 60\% até o ano de 2015 (INCA, 2012).

A origem étnica também vem sendo estudada como fator de predisposição. Um estudo entre norte americanos compreendidos em diversas etnias, verificou que o $\mathrm{CaP}$ foi, aproximadamente, 1,6 vezes mais comum em homens negros do que em homens brancos, e negros apresentaram o dobro do risco de morte por $\mathrm{CaP}$ em relação a homens de etnia branca (JONES R.A. e WENZEL J., 2005; RIES L. et al., 2008). Em relação às demais etnias, verificou-se menor incidência de $\mathrm{CaP}$ em asiáticos, seguidos de hispânicos e brancos (Figura 4). Os americanos, jamaicanos e caribenhos com descendência africana apresentaram as mais altas taxas de incidência desse câncer no mundo, o que pode ser atribuído, em parte, à suscetibilidade genética (cerca de $5 \%$ a 10\%) (RIES L. et al., 2008).

Figura 4- Ajuste da incidência do câncer de próstata por idade, entre diferentes raças/etnias de populações masculinas nos Estados Unidos (2001-2005). Dados de RIES L. et al., 2008 e figura adaptada de CRAWFORD E.D., 2009.

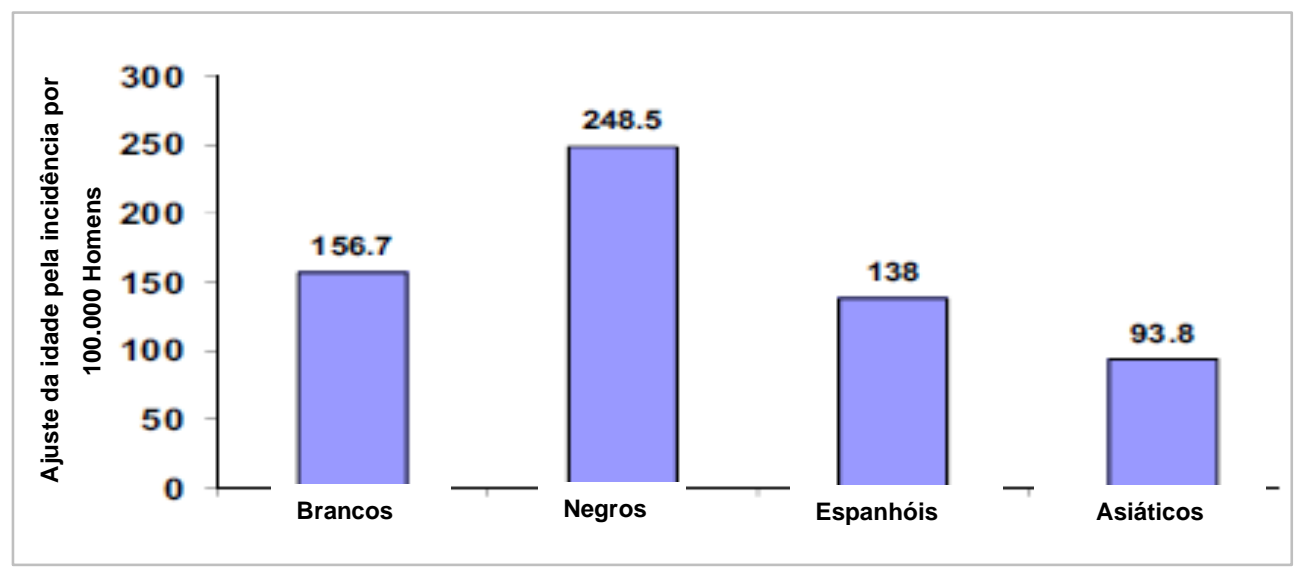

O que se pode dizer é que o CaP é mais prevalente entre europeus e afroamericanos, e raro em asiáticos e africanos. Corroboram para tal inferência, estudos recentes que definiram que há associação entre dois alelos no cromossomo 8q24 em relação ao aumento na incidência de $\mathrm{CaP}$, tanto em europeus da porção norte do continente Europeu, quanto em afro-americanos (AMUNDADOTTIR L.T. et al., 2006; FREEDMAN M.L. et al., 2006; SUURINIEMI M. et al., 2007). Entretanto, é baixa a frequiência desses alelos em africanos nativos e em outros grupos étnicos, sugerindo transmissão pela miscigenação entre europeus e afro-americanos. Outros alelos também foram associados com a alta incidência, dessa forma o $\mathrm{CaP}$ demonstra ser, 
geneticamente, uma doença poligênica, cujos alelos exercem baixa penetrância (XU J. et al., 2005 e CHANG B.L. et al., 2006).

Entretanto, essas disparidades de prevalência entre as etnias do $\mathrm{CaP}$ também podem ser atribuíveis a diferenças ambientais (estilo de vida), estado fisiológico (níveis do hormônio esteroide sexual), bem como a estratégia de detecção (BOSTWICK D.G et al. 2004; PLATZ E.A. e GIOVANNUCCI E., 2004; HAQQ C. et al., 2005). Dessa forma, embora sua ocorrência aparentemente aleatória em uma população possa deverse a baixa penetrância, ela pode, alternativamente, também ser explicada por mecanismos epigenéticos e pela interação gene-ambiente.

Outra consideração é que a alta incidência de $\mathrm{CaP}$ em países desenvolvidos pode ser reflexo do seu bem estabelecido sistema de triagem e registro desse câncer, enquanto que as baixas estimativas em países em desenvolvimento possa ser atribuído ao precário sistema de registro aí estabelecido (LANGEBERG W.J. et al., 2007 e GUNDERSON K. et al., 2011). Sendo assim, visto essas considerações, deve-se ponderar quanto a um possível viés de associação entre incidência e etnia para o CaP.

Dietas baseadas em gordura animal, carne vermelha, embutidos e cálcio, têm sido associadas ao aumento no risco de desenvolver CaP. Além disso, também contribui como fator de risco a obesidade, em especial para aquelas neoplasias de comportamento mais agressivo. Em contrapartida, dietas ricas em vegetais, vitaminas D e E, licopeno e Ômega-3 são considerados como protetoras (MILLER E.C. et al., 2002; VENKATESWARAN V. et al., 2002; GIOVANNUCCI E., 2005; KOBAYASHI N. et al., 2005; FLESHNER N.E, 2009). Todas essas observações levam a crer que certos componentes da dieta asiática (rica em fito-estrógenos) e de áreas do mediterrâneo (rica em antioxidantes- tomates, vegetais, vinho tinto, etc.) inibam o desenvolvimento do $\mathrm{CaP}$ que é tão prevalente em países ocidentais. Outros fatores cujas associações com CaP foram detectadas em alguns estudos incluem o "fator de crescimento análogo à insulina" (insulin-like growth factor), consumo excessivo de álcool, tabagismo e a vasectomia (INCA, 2002).

É possível estabelecer uma relação entre diferentes fatores genéticos e a probabilidade de desenvolvimento do $\mathrm{CaP}$ (Tabela 1). Quanto à origem o $\mathrm{CaP}$ pode ser dividido em: hereditário, familial e esporádico. Mais de $85 \%$ de todos os CaPs são esporádicos e apenas 10-15\% são determinados geneticamente(BRATT O., 2002).O 
aparecimento de um alelo de alto risco de disposição para $\mathrm{CaP}$ é mais frequente em homens diagnosticados em idade mais jovem (43\% dos homens com menos de 55 anos, $34 \%$ dos homens com menos de 70 anos e $9 \%$ de homens mais jovens do que 85 anos de idade). Cânceres esporádicos de próstata ocorrem mais em homens com histórico familiar negativo para a doença. Já o CaP familial afeta dois ou mais homens em uma mesma família, enquanto os CaPs hereditários afetam três ou mais homens em uma família em três subsequentes gerações (CARTER B.S., 1993 e SCHAID D.J. et al., 1998).

Tabela 1: Relação do histórico familiar e o risco de CaP. Adaptada de KRALA M. et al., 2011 e dados de BRATT O., 2002.

\begin{tabular}{lcc}
\hline Histórico familiar de Câncer de Próstata & Risco relativo & Risco absoluto \\
\hline Não & 1 & 8 \\
Pai ou irmão & 2 & 15 \\
Pai ou irmão, acometidos antes dos 60 anos & 3 & 20 \\
Pai e irmão & 4 & 30 \\
CaP hereditário & 5 & $35-45$ \\
\hline
\end{tabular}

Um estudo de meta-análise de 33 estudos epidemiológicos sobre o risco de $\mathrm{CaP}$ familiar mostraram que o risco relativo em um homem com um irmão ou o pai com o $\mathrm{CaP}$ é de 3,4 e 2,2, respectivamente. Não só a história familiar de CaP, mas também de câncer de mama/ovário aumentam o risco para os homens em uma mesma família. Em tal caso, o risco relativo é de 1,7 e em caso de incidência do CaP, câncer de mama/ovário, é de 5,8 (BRUNER D.W. et al., 2003 e ZEEGERS M.P et al., 2003).

Recentemente, descobriu-se um número de genes supressores tumorais e protooncogenes que desempenham um papel crítico no desenvolvimento e progressão do $\mathrm{CaP}$, tais como o gene supressor de tumor NKX3.1, PTEN, e proto-oncogene MYC, NOTCH-1 (SHEN\& ABATE-SHEN, 2010). Além disso, foi detectada uma translocação cromossômica recorrente envolvida na tumorigênese da próstata. Especificamente, é uma a translocação de um fator de transcrição ETS-ERG à região promotora TMPRSS2 resultando numa forma constitutivamente ativa da proteína de fusão TMPRSS2ERG,ocorrendo em aproximadamente $40 \%$ dos tumores de próstata primários (MANI et al., 2009;. TOMLINS et al., 2005). Fusões envolvendo outros membros dos fatores de 
transcrição ETS, ETV1 e ETV4 e ETV5, também foram encontrados em CaP humano, em uma frequência menor (CLARK\& COOPER, 2009).

Também foi visto que a ZP está mais propensa a desenvolver o tumor, pois apresenta expressão diferencial de genes que estão envolvidos em rearranjos (principalmente o rearranjo entre os genes TMPRSS2 e ERG que são relativamente comuns no $\mathrm{CaP}$, em relação a ZT. A ZP está em contato íntimo com o estroma, facilitando o contato com andrógenos que atuam modulando os rearranjos gênicos. Essa expressão diferencial da ZP em relação à ZT sustenta a hipótese de que o microambiente da ZP dá suporte ao crescimento tumoral (VAN DER HEULNIEUWENHIJSEN L. et al., 2006 e SKHIBRAHIMHA Z. et al., 2011).

Estudos citogenéticos e moleculares prévios mostraram que os adenocarcinomas da próstata tendem a apresentar frequentes perdas de loci cromossômicos específicos, como 2q, 3q, 5q, 6q, 7q, 8q, 10q, 13q, 16q e 18q (COONEY K.A., et al. 1996 e SRIKANTAN V., et al.1999). Muitas das perdas nesses cromossomos resultam em rearranjos cromossômicos que já foram bem caracterizados em algumas neoplasias (ROWLEY J. D., 2001). As fusões gênicas decorrentes desses rearranjos são eventos primários na evolução de algumas neoplasias não epiteliais, como linfomas, sarcomas e leucemias (ROLEY J.D., et al. 2001).

\subsubsection{DIAGNÓSTICO E PROGNÓSTICO DO CaP}

A triagem do CaP deve envolver tanto o toque retal quanto a avaliação dos níveis de PSA no sangue. A idade de início do rastreamento ainda não foi precisamente definida. Há estudos que recomendam uma avaliação anual a partir dos 40 anos (THOMPSON I. et al., 2007), no entanto, a grande maioria dos estudos recomendam uma avaliação anual a partir dos 50 anos de idade (US PREV. SERV. TASK FORCE, 2008 e BROOKS D.D. et al., 2010). Caso haja um histórico familiar de CaP diagnosticado antes dos 65 anos ou o indivíduo tenha ascendência negra, preconiza-se a realização do exame anual a partir dos 40 anos de idade (BROOKS D.D. et al., 2010).

O toque retal é o teste mais utilizado, apesar de suas limitações, já que somente as porções posterior e lateral da próstata podem ser palpadas, deixando $40 \%$ a $50 \%$ dos tumores fora do seu alcance. As estimativas de sensibilidade variam entre $55 \%$ e $68 \%$. O valor preditivo positivo é estimado entre $25 \%$ e $28 \%$. Quando utilizado em 
associação à dosagem do PSA com valores entre 1,5ng/ml e 2,0 ng/ml, sua sensibilidade pode chegar a $95 \%$ (INCA, 2002).

A Sociedade Americana do Câncer (ACS) também recomenda que o exame possa ser interrompido aos 75 anos, devida a baixa probabilidade de morte pelo $\mathrm{CaP}$ nessa idade e, esclarecendo aos pacientes para que compreendam os benefícios e os riscos de qualquer uma das condutas (BROOKS D.D. et al., 2010). Uma desvantagem do rastreamento é a baixa especificidade que resulta em alto número de biópsias negativas com o consequente aumento de custos, de ansiedade e de morbidade (RIETBERGEN J.B. et al., 1997).

A confirmação do diagnóstico do $\mathrm{CaP}$ é feito pelo estudo histopatológico do tecido obtido pela biópsia da próstata, que deve ser considerada sempre que houver anormalidades no toque retal ou na dosagem do PSA. O relatório anatomopatológico deve fornecer a graduação histológica do sistema de Gleason, cujo objetivo é informar sobre a provável taxa de crescimento do tumor e sua tendência à disseminação, além de ajudar na determinação do melhor tratamento para o paciente (INCA, 2002).

Além do diagnóstico, também é essencial o estabelecimento do prognóstico para a definição de protocolos e a indicação ou contra-indicação das modalidades terapêuticas e para o acompanhamento e avaliação de sua efetividade. No CaP, classicamente, três fatores são fundamentais no prognóstico da doença: o estadiamento, o grau histológico e o antígeno prostático específico (PSA) (POTTER S.R. et al., 2001). Há fatores adicionais que sabidamente podem influenciar a evolução. Diversas outras variáveis clínicas, patológicas e biomoleculares estão em estudo e podem se tornar, de forma isolada ou conjunta, adjuvantes na construção de modelos prognósticos (ALTMAN D.G., 2001 e CORRÊA L.A. et al., 2006).

O estadiamento avalia a extensão anatômica do tumor. A classificação TNM (TT- extensão do tumor primário, N- a ausência ou presença e a extensão de metástase em linfonodos regionais, M- a ausência ou presença de metástase à distância) (GREENE F.L. et al., 2002; SOBIN, L.H \& COMPTON, C.C., 2010) é aceita internacionalmente para descrever e comparar padrões de apresentação da doença, impacto do rastreamento e acesso ao tratamento. Os pacientes, então, podem ser classificados em baixo, médio e alto risco (Tabela 2) de acordo com dados da biópsia, PSA, Grau de Gleason (GG) e critérios da biópsia. 
TABELA 2: Classificação Tumor Nodo Metástase (TNM) para câncer de próstata. Tabela adaptada de PETTUS et al., 2008.

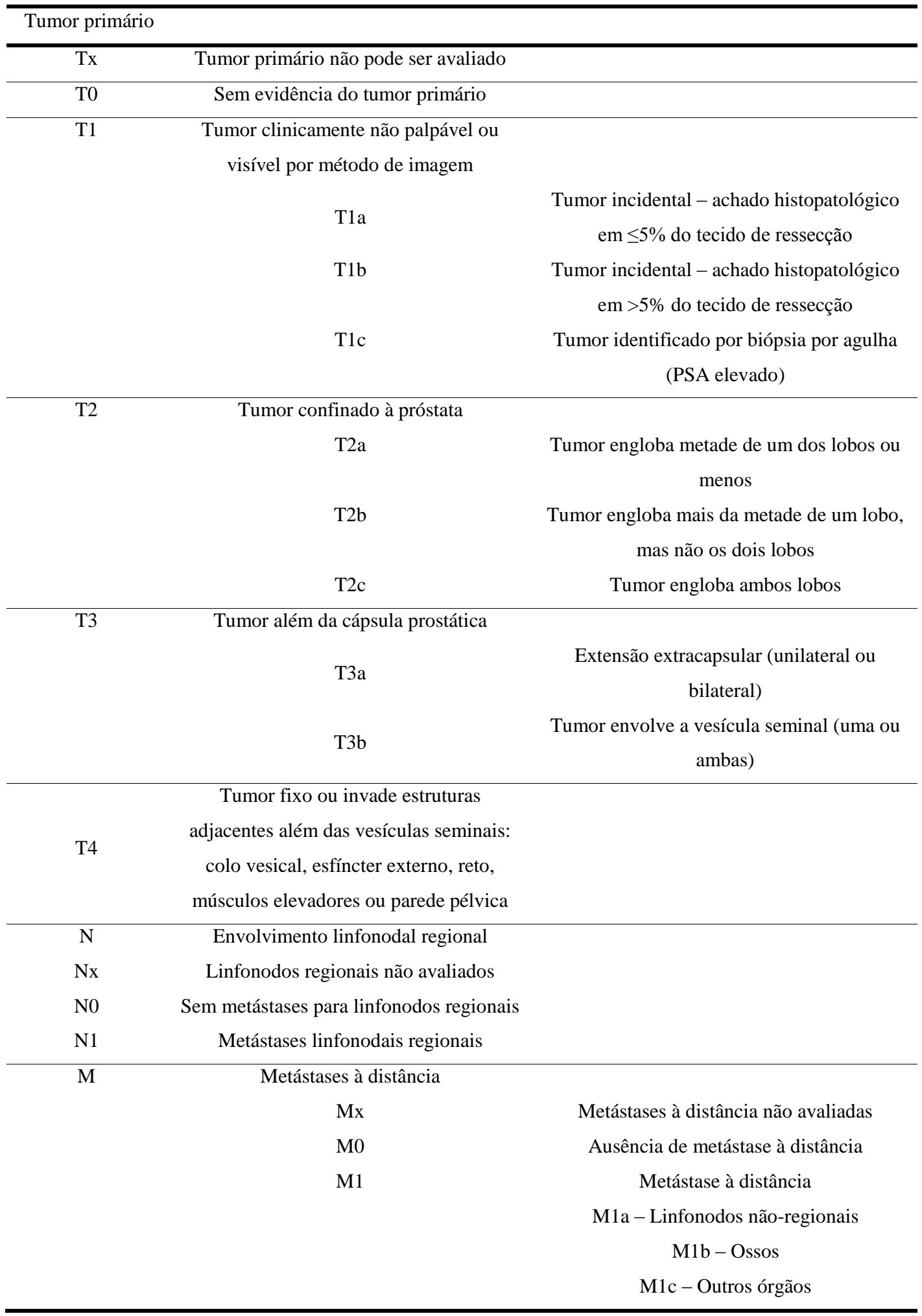


Já para o exame da glândula prostática são ainda utilizados:

- O exame retal (ER): a sensibilidade de predizer doença restrita ao órgão é de cerca de $50 \%$ e a especificidade é de 80\%(PARTIN A.W. et al. 1997);

- A ultra-sonografia transretal da próstata (USTR): o seu valor isolado não é maior que o ER da próstata, com valor preditivo de aproximadamente 50\% (HAMDY F.C., 2001).

Já o PSA é marcador tecidual, porém não tumor específico. Suas sensibilidade e especificidade não permitem a utilização do mesmo como método isolado. Entretanto, na avaliação da doença primária existem algumas informações que o valor de PSA pode fornecer:

- Teor < 4 ng/ml: há $80 \%$ de probabilidade de a doença estar restrita ao órgão (análise de peças de prostatectomia radical) (POLASCIK T.J. et al., 1999);

- Teor < $10 \mathrm{ng} / \mathrm{ml}$ : cintilografia óssea e tomografia computadorizada da pelve são, na avaliação de rotina, provavelmente desnecessárias devido ao baixo risco de metástases à distância (POLASCIK T.J. et al., 1999).

- Teor > 10 ng/ml: o risco de extensão extracapsular é acima de 60\%(POLASCIK T.J. et al., 1999);

- Teor > $50 \mathrm{ng} / \mathrm{ml}$ : risco altamente significante de doença metastática à distância (POLASCIK T.J. et al., 1999).

Por outro lado, a concentração sérica de PSA é utilizada na monitorização do tratamento. Assim:

- Se a taxa de PSA não desce a nível indetectável após prostatectomia radical, ou aumenta a despeito da radioterapia ou da crioterapia realizadas, ou se aumenta dentro do primeiro ano após a realização de qualquer tratamento local ou se, ainda, dobra de valor em menos de seis meses, provavelmente o paciente apresenta metástase à distância (KOCH M.O. et al., 2000);

- Nível detectável de PSA após prostatectomia radical está associado com recorrência da doença em muitos pacientes, sendo que o intervalo médio entre a recorrência do PSA e a morte por câncer situa-se entre cinco e 12 anos, dependendo do escore de Gleason (KOCH M.O. et al., 2000);

- Após radioterapia, o nível de PSA diminui, em média, após 17 meses. Pacientes que apresentam valor abaixo de $0,5 \mathrm{ng} / \mathrm{ml}$ ou taxa indetectável por pelo menos cinco anos, provavelmente, não apresentarão falha do tratamento efetuado (GREENE K.L. et al., 2013); 
- Após radioterapia, três aumentos consecutivos PSA, estão associados à falha do tratamento (POLASCIK T.J. et al., 1999);

- No caso de doença avançada, o PSA é, provavelmente, o melhor marcador da eficácia do tratamento, sendo que aumento secundário do PSA é preditivo de falência do tratamento hormonal de primeira linha (GREENE K.L. et al., 2013);

- Em pacientes com doença metastática, que recebem privação androgênica, o nível do PSA deve baixar, o porcentual de declínio aos três e aos seis meses pode traçar um prognóstico evolutivo da doença e, assim, nos pacientes cujo teor de PSA é indetectável e naqueles cujo PSA diminui $90 \%$ ou mais, aos três e seis meses após o início do tratamento, experimentarão muito provavelmente uma sobrevida prolongada (GREENE K.L. et al., 2013);

- Métodos de biologia molecular, como RT-PCR (reação em cadeia da polimerase e transcriptase reversa), para PSA no sangue periférico com resultado positivo, sugere a presença de células prostáticas (o RNA mensageiro para PSA é prostático-específico), porém o significado deste achado em pacientes submetidos à prostatectomia radical necessita ainda maior comprovação científica acerca do seu real valor clínico (SU S.L. et al., 2000).

O GG correlaciona-se com a extensão da doença, particularmente com o risco de acometimento extra-prostático, assumindo valor prognóstico independente (RUBIAN M.A. et al., 2000). O sistema é graduado de dois a dez, sendo dois o menos agressivo e dez o mais agressivo. Considera- se que tumores com GG igual ou maior que sete são biologicamente agressivos, com grau de cinco ou seis são tumores com agressividade intermediária, e tumores com grau situado entre dois e quatro têm agressividade biologicamente menor. Geralmente ele é expresso do seguinte modo: p.ex - Gleason7 $(3+4)$. O primeiro algarismo corresponde ao tipo de célula mais presente, e o segundo, o segundo tipo mais presente na biópsia ou análise da ressecção prostática (POLASCIK T.J. et al., 1999 e BOORJIAN S.A. et al., 2008).

Tem-se procurado associar as características histológicas do tumor como o grau de Gleason a um importante número de variáveis prognósticas (volume tumoral, estadiamento patológico, zona prostática de origem, presença de metástases nos linfonodos e margens cirúrgicas) (PARTIN A.W. et al. 1990). A partir do escore de Gleason, do valor de PSA, do estadiamento clínico e patológico, além do seguimento de grande número de homens submetidos a prostatectomia radical, construiu-se tabelas prevendo as probabilidades de sobrevida quando o tumor está restrito ao órgão ou 
compromete a cápsula prostática, vesículas seminais e linfonodos pélvicos (POLASCIK T.J. et al., 1999). Já os fatores prognósticos adicionais permitem refinamentos na análise dos resultados, porém não são normalmente utilizados no processo de seleção do tratamento (POTTER S.R. et al., 2001).

\subsection{BIOMARCADORES DO CaP}

\subsubsection{MARCADORES DE PROTEÍNAS}

\section{a. Antígeno Prostático Específico (PSA)}

A partir de 1986, instituiu-se na prática clínica o teste do Antígeno Prostático Específico (PSA) como principal biomarcador para triagem do CaP (CATALONA W.J., et al., 1991). Desde então, tornou-se possível identificar a doença em estágios mais precoces do que era possível antes da "era PSA", promovendo o CaP ao status de câncer mais diagnosticado em homens nos últimos tempos, principalmente nos Estados Unidos, país onde esses dados são atualizados e disponibilizados com mais frequência, diferentemente do que acontece na maioria dos países em desenvolvimento, como por exemplo, no Brasil, onde esses dados são mais escassos e frequentemente desatualizados (SIEGEL R. et al., 2011).

Enquanto a incidência vem crescendo continuamente, a mortalidade manteve-se praticamente a mesma. Antes da "era do PSA", o maioria dos carcinomas da próstata eram diagnosticados em exame de toque retal ou pela histologia de prostatectomias (ressecção transuretral ou prostatectomia suprapúbica). Hoje, é possível diagnosticar mais de $70 \%$ dos CaPs com elevado PSAs, identificando-os dez anos antes do que era possível no passado. Esse potencial diz respeito não só ao tempo, mas também ao potencial biológico de detectar o câncer em estágio de menor malignidade (menor graduação histopatológica e menor estadiamento). Por outro lado, a maior prevalência de câncer agressivo é afetada pelas recomendações para a classificação do CaP (Grau de Gleason) realizada na Conferência de Uropatologistas (ISUP) em 2005 (MERRIL R.M. \& STEPHENSON R.A., 2000 e EPSTEIN J.I. et al., 2005).

Ainda que não seja possível estabelecer a proporção na redução da mortalidade, é evidente que ela é resultado não só da aplicação da triagem pelo PSA, mas também da melhoria da qualidade do tratamento e as mudanças nos registros de codificação 
(STAMATIOU K.S., 2011). Entretanto, apesar das conquistas, é recomendável ponderar a influência dos vieses de interpretação que os resultados do teste de PSA podem exercer sobre as taxas de mortalidade e de declínio da doença, caso não se leve em consideração outras variáveis clínicas (FEUER E.J. et al., 1999). Por exemplo, o estágio, grau da doença, etnia, comorbidades, idade do diagnóstico e de morte são fatores relevantes nessa análise (MERRIL R.M. \& STEPHENSON R.A., 2000).

Além disso, deve-se considerar que sua sensibilidade e especificidade são limitadas, embora seja empregado de rotina na triagem clínica não invasiva (DE ANGELIS G. et al., 2007). Como o antígeno dosado é produzido pelas células epiteliais da próstata e não especificamente pela célula cancerosa, a dosagem do PSA pode estar alterada em outras patologias que não o câncer, como na prostatite e na hiperplasia benigna da próstata, assim como após a ejaculação e a realização de uma cistoscopia (INCA, 2002).

Dados recentes identificaram um número substancial de homens cujo nível de PSA se encontrava na faixa do considerado "normal" (por exemplo, PSA de 4ng/ ml) e, no entanto, mais de $20 \%$ apresentavam CaP pela análise de biópsia prostática. Entre aqueles positivos na biópsia, muitos foram considerados portadores de $\mathrm{CaP}$ de alto estadio, portanto clinicamente significativos. Sendo assim, entende-se que não há nível de PSA seguro, com alta sensibilidade e especificidade simultâneas, para o monitoramento de homens saudáveis para detecção de CaP (THOMPSON I.M. et al., 2004 e THOMPSON I.M. et al., 2005 ).

Apesar de todas essas controvérsias, o teste de PSA no soro ainda é o mais importante biomarcador para a detecção e seguimento do CaP. O teste é bem tolerado, rápido, barato e padronizado. Os médicos estão familiarizados com os resultados destes testes e com ele são capazes de predizer o nível de risco para a doença ou de progressão tumoral. Cerca de 70 a $80 \%$ das biópsias de próstata são desnecessárias, dependendo do nível de PSA no soro estabelecido (SCHRÖDER F.Het al., 2009), pois o teste de PSA pode levar ao sobrediagnóstico, muitas vezes resultando em sobretratamento, devido, principalmente, a sua baixa sensibilidade (HEIJNSDIJK E.A. et al., 2009). 


\section{b. Outros marcadores proteicos}

No CaP a anexina A3 (ANXA3), uma proteína ligante de cálcio, se encontra em baixas concentrações. A quantificação da ANXA3 de amostras de urinas de pacientes com CaP, utilizando-se Western blot, foi bem menor em comparação com pacientes portadores de hiperplasia prostática, demonstrando uma alta especificidade e um aumento da sensibilidade em relação ao teste de PSA (SCHOSTAK M. et al., 2009). Esse estudo sugere que se utilize tanto o PSA quanto o ANXA3 presentes na urina para obtenção de melhor sensibilidade e especifidade na detecção e determinação prognóstica do CaP.

As metaloproteínas presentes na urina de pacientes com $\mathrm{CaP}$ foram relacionadas à invasão, crescimento e metástase no CaP (EGEBLAD M. et al., 2002) e sua detecção mostrou uma especificidade de $82 \%$ e uma sensibilidade de $74 \%$ (ROY R. et al., 2008). Recentemente, outros marcadores proteicos verificados na urina foram relacionados ao CaP, como a delta-catenina (LU Q.et al., 2009) o fator de crescimento de hepatócito (cMet) (RUSSO A.L. et al., 2009) e a timosina $\beta 15$ (HUTCHINSON L.M. et al., 2005) porém ainda não foram validados em estudos populacionais.

Também tem se estudado a correlação entre resíduos metabólicos presentes na urina e o CaP. Adachi et al. (2006) demonstraram a ocorrência de mais de 1500 destes resíduos considerados normais presentes na urina, e conjuntamente a dados de proteômica do $\mathrm{CaP}$ propõe-se o de desenvolvimento de uma nova abordagem diagnóstica de detecção e proposta terapêutica para o CaP (ADACHI J. et al., 2006; SREEKUMAR A. et al., 2009 e GOO Y.A. \& GOODLETT D.R., 2010).

\subsubsection{BIOMARCADORES DE DNA}

A hipermetilação em loci genéticos diferentes tem sido associada com a maioria dos tumores malignos, e vários marcadores de DNA de metilação têm sido investigados. A perda de expressão da glutationa-S-transferase P (GSTP1) como um resultado da hipermetilação do promotor é a alteração molecular mais comum relatada em $\mathrm{CaP}$ (HARDEN S.V. et al., 2003). Entretanto há resultados conflitantes entre alguns estudos a respeito da precisão da predição dos testes empreendidos para esse biomarcador (PLOUSSARD G. \& de la TAILLE, 2010). 
Vários ensaios a respeito da metilação de outros genes, como o GSTP1, RARB e APC foram recentemente testados mostrando bons valores preditivos, apesar de um ganho superior não tão significativo em relação à mesma capacidade preditiva da biópsia e da avaliação de PSA (BADEN J. et al., 2009 e PAYNE S.R. et al., 2009). Apesar dos resultados até aqui terem sugerido que a metilação pode servir como um marcador útil para o $\mathrm{CaP}$, sendo a hipermetilaçãodo GSTP1 o mais promissor marcador individual, maiores estudos clínicos prospectivos de marcadores individuais e avaliação de painéis de genes são necessários para validar a sua utilidade clínica.

\subsubsection{BIOMARCADORES DE RNA}

Os marcadores de RNA presentes são os que apresentam maior desenvolvimento. O teste para detecção do PCA3 já está comercialmente disponível sob o nome comercial de Progensa ® PCA3 (Gen-Probe, SanDiego, Ca) (GROSKOPF J. et al., 2006). O teste PCA3 mostrou ser mais preditivo que o nível de PSA no soro em prever resultados de biópsias. Possui uma alta especificidade de 80 a 90\%, podendo vir a se evitar biópsias desnecessárias. Entretanto deve-se atentar para os valores de sensibilidade que ficaram em torno de 53 a $84 \%$, questionando o seu valor clínico (VLAEMINCK-GUILLEM V. et al., 2010).

A relação entre o nível de PCA3 e parâmetros de agressividade do CaP têm sido estudados com diferentes resultados. Há estudos (HESSELS D.et al., 2010) que relatam uma relação positiva enquanto outros já não demonstram essa mesma relação (WHITMAN E.J. et al., 2008). É importante perceber, então, que as interpretações destes dados estão sujeitas a vieses.

Outros biomarcadores urinários de RNA são os transcritos do gene de fusão TMPRSS2-ERG, que constitui o rearranjo mais comum no CaP. Hessels et al., 2010, analisaram a presença desses transcritos e novamente a sensibilidade foi baixa (37\%) e a especificidade muito alta (93\%), sendo que nenhuma relação significativa foi encontrada entre a presença desses transcritos e o escore de Gleason das biópsias. Este encontro foi confirmado por Rice et al., 2010, que detectou a presença do mRNA (RNA mensageiro) de fusão do $E R G$ em amostras de urina de 237 homens.

Entretanto, quando combinados, o teste do PCA3 e da fusão TMPRSS2-ERG verificou-se uma melhora significativa da predição para o CaP (AUBIN S.M. et al., 2008). Complementando este duplo teste com o nível de PSA o resultado foi ainda mais 
significativo. Uma análise múltipla desses marcadores melhora a sensibilidade em testes de amostras de urinas, sem comprometimento da especificidade (LAXMAN B. et al., 2008).

\subsection{TRATAMENTO DO CaP}

Nos últimos anos, houve uma ampliação dos métodos terapêuticos com a aprovação de vários agentes que demonstraram prolongar a vida de pacientes com $\mathrm{CaP}$ resistentes à castração (BONO J.S. et al., 2010; KANTOFFP.W. et al., 2010; BONO J.S. et al., 2011). Entretanto, muitos deles são diagnosticados com $\mathrm{CaP}$ localizado, que constituem a maioria dos homens diagnosticados com a doença, representando um desafio para o clínico determinar o prognóstico e a estratégia terapêutica. A abordagem terapêutica tradicional para o $\mathrm{CaP}$ é a excisão cirúrgica ou a radioterapia, associados a efeitos colaterais, psicológicos e resistência (SANDA M.G. et al., 2008;ALEMOZAFFAR M. et al., 2011).

Hoje, há uma estratégia bem aceita denominada conduta de espera, aplicada principalmente em pacientes idosos com comorbidades significativas. O paciente não é tratado até que a doença torne-se sintomática, o que é geralmente associada à doença localmente avançada ou metastática. Nessa situação, há indicação de intervenção paliativa, como a terapia de ablação androgênica, radioterapia focal para aliviar a dor óssea ou ressecção transuretral da próstata a fim de aliviar a obstrução do trato urinário (BILL-AXELSON A. et al., 2011).

Outra abordagem terapêutica utilizada é a vigilância ativa. O objetivo é acompanhar as mudanças da agressividade do câncer por meio de biópsias de série e medidas dos níveis de PSA, caso uma mudança significativa seja detectada, intervém-se por meio de terapia local definitiva. Seriam elegíveis pacientes com escore de Gleason inferior a $3+4=7$, e níveis de PSA de até $15 \mathrm{ng} / \mathrm{ml}$, considerados de risco intermediário dependendo da idade e de comorbidades (TOSOIAN J.J. et al., 2011). Esta abordagem desempenha um papel importante na redução dos danos associados ao tratamento tradicional do CaP, porém há muitos desafios a trilhar, como padronização dos critérios de inclusão e o regime de vigilância que redundaria ou não na intervenção invasiva (SANDA M.G. et al., 2008;ALEMOZAFFAR M. et al., 2011). 
A fim de aperfeiçoar os fatores de inclusão na vigilância ativa e os possíveis desfechos terapêuticos, os pesquisadores vêm concentrando esforços na pesquisa porbiomarcadores, diagnósticos por imagem e terapia focal para otimizar os esquemas de vigilância ativa, melhorar os resultados dos pacientes e até mesmo com esses dados descobrir e implementar estratégias de prevenção do CaP (AUPRICHM. et al., 2010;PLOISSARD G.et al., 2011; RUBIAN M.A.et al., 2011).

Nesse contexto e diante de tudo aqui exposto a respeito do CaP, verifica-se que apesar dos recentes avanços nas modalidades de tratamento, cirurgias, radiação, e terapias hormonais há ainda uma série de complicações para os pacientes com CaP.Dadas estas limitações, estudos vêm sendo empreendidos com objetivo principal de buscar genes alterados nessa neoplasia, particularmente aqueles envolvidos com a sinalização de receptores de andrógenos, bem como encontrar novos alvos para o tratamento e detecção precoce do carcinoma metastático. Dessa maneira, é necessário o desenvolvimento de métodos de distinção dos cânceres agressivos daqueles indolentes para que a morbidade significativa, resultante de tratamentos equivocados, seja reduzida (MICHAELSON M.D., et al. 2008). Além disso, os métodos atuais de tratamento para casos metastáticos avançados frequentemente mostram ser insuficientes a longo tempo.

Sendo assim, empreendemos nesse trabalho uma investigação por um biomarcador de alteração molecular, altamente relevante para o $\mathrm{CaP}$, que orienta o desenvolvimento da progressão tumoral na próstata. Este marcador teria implicações substanciais para os critérios empregados tanto na vigilância ativa quanto na abordagem terapêutica de escolha e também é apontado como possível indicador prognóstico. Trata-se dos transcritos do gene de fusão TMPRSS2-ERG, que atualmente podem ser detectados até mesmo na urina, como visto anteriormente (HESSELS et al., 2010).

\subsection{O REARRANJO TMPRSS2/ERG}

Nas neoplasias epiteliais (carcinomas) os rearranjos cromossômicos conhecidos representam menos que $1 \%$ das doenças com rearranjos cromossômicos específicos (MITELMAN F., et al. 2004). Sugere-se que algumas das limitações na descoberta desses rearranjos em neoplasias epiteliais consistam na dificuldade de cultivo das células epiteliais tumorais o que compromete a análise cariotípica, e no padrão nãoespecífico de mudanças cromossômicas que dificulta a identificação das alterações (MITELMAN F., et al. 2004). Entretanto, com o avanço científico das técnicas de 
detecção desses rearranjos, muitos deles vêm sendo identificados (KUMAR-SINHA C., et al. 2008).

TOMLINS et al. (2005), trabalhando com um algoritimo (COPA- Cancer Outlier Profile Analysis) para analisar os perfis gênicos diferenciais gerados por microarrays de amostras de CaP, identificaram recorrentes rearranjos cromossômicos e amplificações que estão diretamente envolvidos na patogênese dessa neoplasia prostática. A pesquisa resultou na identificação da fusão de elementos andrógenoresponsivos do promotor do gene TMPRSS2 (21q22.2) ao oncogene semelhante ao vETS do vírus da eritroblastose E26 $(E R G, 21 q 22.3)$ ou a uma sequência transformante do vírus da eritroblastose E26 do gene variante 1 (ETV1, 7p21.2), pertencentes à família ETS de fatores de transcrição (TOMLINS S.A., et al. 2005 e MORRIS D. S. et al., 2008).

Como os genes TMPRSS2 e ERG estão distantes um do outro por $3 \mathrm{Mb}$ no cromossomo 21, o rearranjo entre eles pode ocorrer pela translocação entre os pares do cromossomo 21, devido a homologia entre seus loci, ou por deleção intersticial entre eles no mesmo cromossomo (Edel) (PERNER S., et al. 2006 e YOSHIMOTO M., et al. 2008). Esta situação pode ser visualizada pela comparação dos sinais observados por Hibridização por Fluorescência in situ (FISH) em células normais da próstata e células cancerosas portadoras do rearranjo TMPRSS2/ERG (Figura 5). A primeira apresenta dois sinais, fluorescência das sondas 5'ERG (verde) e 3'ERG (vermelho) que hibridizam no locus do gene $E R G$ (Figura 5). Já nas células cancerosas da próstata portadoras da fusão verificam-se padrões de fluorescência distintos do primeiro, nos quais se têm um panorama das possibilidades de rearranjo entre o gene TMPRSS2 e o gene $E R G$ (MACKINNON A.C. et al., 2009).

Mais de $90 \%$ das fusões do gene TMPRSS2 com os membros da família ETS correspondem a fusão TMPRSS2A:ERG (KUMAR-SINHA C., et al. 2008), onde os rearranjos de TMPRSS2:ETV1, TMPRSS2:ETV4, e TMPRSS2:ETV5 ocorrem raramente. Embora os testes de hibridação in situ fluorescente (FISH) em larga escala utilizando microarrays de tecido, sejam úteis em avaliações para determinação da prevalência dessas fusões em $\mathrm{CaP}$, não são ideais, visto que a caracterização das fusões dos transcritos por amplificação de cDNA e $R T-P C R$ revelaram uma grande extensão de transcritos variantes. A mais comum delas envolve a fusão do éxon1 ou 2 do gene TMPRSS2 com os éxon 3, 4, ou 5 do gene ERG. A combinação menos frequente inclui o éxon 4 ou 5 do TMPRSS2 com o éxon 4 ou 5 do ERG (Figura 6). A maioria das 
explicações para essa variabilidade de transcritos atribui-a ao splicing alternativo, pois é improvável que múltiplas fusões entre dois genes específicos estejam presentes em um mesmo tumor (WANG J. et al., 2006). Além disso, o splicing alternativo para o gene $E R G$ já foi descrito (OWCZAREK C.M. et al., 2004).

O gene TMPRSS2 codifica a proteína TMPRSS2, uma protease transmembrana ligada a serina predominantemente associada à membrana da face luminal do epitélio prostático, com uma menor expressão em outros órgãos: pâncreas, rim, pulmão, cólon e fígado (PAOLONI-GIACOBINO A., et al. 1997; LIN B., et al. 1999 e VAARALA M.H., et al.2001). Sua expressão é andrógeno-dirigida (LIN B.Y., et al. 1999), encontrando-se super expresso em pacientes com $\mathrm{CaP}$, o que faz deste gene um potencial marcador genético da doença. Entretanto, verificou-se que sua expressão está diminuída durante a transformação das linhagens celulares de $\mathrm{CaP}$ para clones andrógenos-independentes (VAARALA M.H., et al. 2000). Já o $E R G$, que é um fator de transcrição, atua em cooperação com outros fatores de transcrição na regulação de diversas funções celulares, tais como a proliferação, diferenciação, angiogênese, hematopoiese, transformação oncogênica e apoptose (SETH A., et al. 2005).

No CaP a fusão permite que estes genes ETSs sejam superexpressos mediante estímulo androgênico, uma vez que ele passa a responder ao promotor do gene TMPRSS2 (TOMLINS S.A., et al. 2005 e WANG J.A., et al. 2006). Esse rearranjo confere uma biologia distinta ao tumor, uma vez que esses genes da família ETS passam a atuar como oncogenes e, provavelmente em colaboração com outros eventos, promovem a proliferação tumoral (SHAH R.B., et al. 2009).

Recentemente, TOMLINS et al. (2005) demonstraram que $79 \%$ dos casos de $\mathrm{CaP}$ estudados continham o rearranjo gênico. Em estudos subsequentes, de SOLLER et al. (2006) e YOSHIMOTO et al. (2008) frequências de $40 \%$ e $78 \%$ foram identificadas, este último trabalho inclusive trabalha com amostras de pacientes de origem brasileira. Embora estes rearranjos sejam um fenômeno comum no CaP, ainda não está claro em qual estágio da patogênese ele ocorre. Entretanto, verificou-se que a super expressão destes genes é mutuamente exclusiva, levantando a possibilidade de que esse evento seja um ponto de partida no desenvolvimento dessa neoplasia (TOMLINS S.A., et al. 2005).

Diante desse impasse, outro estudo foi empreendido (TOMLINS S.A. et al., 2007) e sugeriu-se que tais rearranjos ETS são suficientes para iniciar a neoplasia prostática, enquanto que, mais recentemente, outro estudo sugeriu que os rearranjos 
possam fomentar mais a progressão do que os eventos iniciais da tumorigênese prostática (CARVER B.S et al., 2009).

Em um estudo com 32 amostras de CaP multifocal proveniente de uma ressecção de prostatectomia total, aproximadamente, $47 \%$ dos casos não continham a fusão e entre aqueles que continham somente cerca de $24 \%$ apresentavam a fusão em todos os focos do tumor, sendo que os demais apresentaram um perfil heterogêneo de expressão (BARRY M., et al. 2007). Essa evidência sugere que embora a fusão TMPRSS2/ETS esteja presente em muitos CaPs, elas podem ocorrer em estágios mais tardios da doença (MAKAROV D.V., et al. 2009).

MACKINNON et al. (2009) revisaram os 17 diferentes tipos de fusão TMPRSS2/ERG identificados até então, apontando que oito destes transcritos provavelmente não resultavam na tradução de proteínas ERG funcionais devido a introdução prematura de códons de parada. Dos nove transcritos da fusão TMPRSS2/ERG provavelmente funcionais, dois codificam proteínas ERG normais, seis codificam proteínas ERG amino-terminais truncadas, e um codifica uma proteína genuína de fusãoTMPRSS2/ERG. Visto a grande variabilidade de transcritos para essa fusão, sugere-se que o splicing alternativo do gene TMPRSS2/ERG seja um dos eventos responsáveis pelos múltiplos tipos de mRNAs de fusão. 
Figura 5 - Adaptada de MACKINNON A.C. et al., 2009. Modelo de rearranjo gênico TMPRSS2/ERG por padrões de hibridização fluorescente in situ (FISH) observados no CaP. A - Mapa físico dos loci TMPRSS2 e ERG em 21q22.2-22.3. T e C é a orientação para as regiões teloméricas e centroméricas, respectivamente. As sondas referentes à região $5^{\prime} E R G$ (verde) e $3^{\prime} E R G$ (vermelho) estão posicionados acima do cromossomos, relativo ao local onde elas hibridizam. Os loci TMPRSS2 e ERG são separadas por cerca de 3 MB. B, a estrutura cromossômica (superior) e padrão de FISH (inferior) observados em um locus do $E R G$ normal. C, Os loci 5' e 3'do $E R G$ separados devido ao rearranjo do gene, referido como Esplit. D, estrutura e padrão cromossômmico de FISH observada com uma deleção intersticial do lócus 5'ERG. Este é o padrão de rearranjo gênico TMPRSS2/ERG mais comum observado no CaP, referido como 1Edel. E, deleção intersticial do locus $5^{\prime} E R G$ acompanhado por uma duplicação de uma sequência 3'ERG. Este padrão do rearranjo TMPRSS2/ERG tem sido referido como 2 Edel.

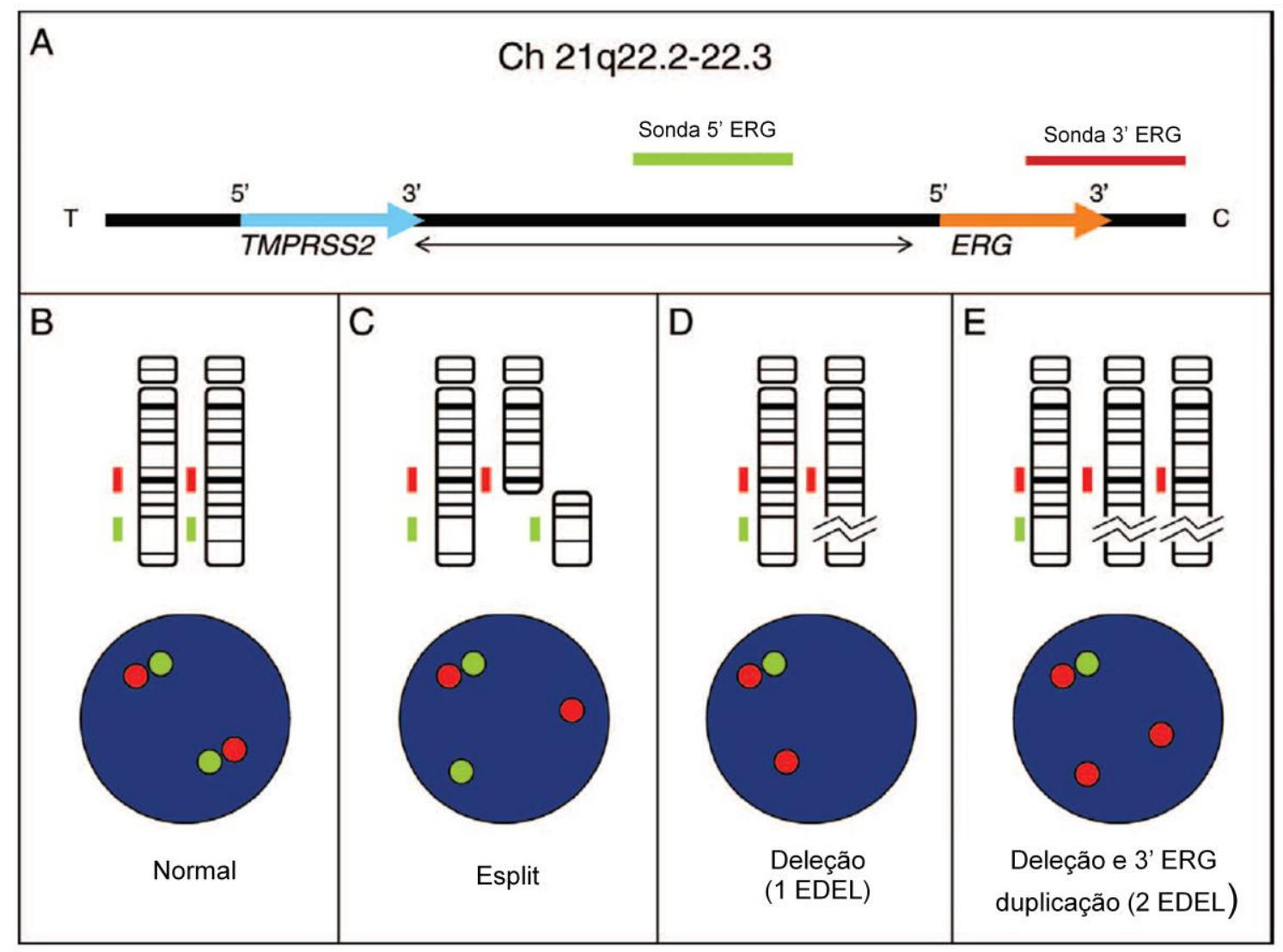


Figura 6 - Esquema adaptado de WANG et al. (2006), mostrando as isoformas dos mRNAs do rearranjo TMPRSS2/ERG no CaP. Os éxons são mostrados em retângulos, sendo azul para o gene TMPRSS2 e lilás para o gene ERG, $e$ são numerados de acordo com sequências de referência do GenBank (NM_005656 e NM_00449). Os números acima dos éxons dizem respeito à última base de cada éxon, as setas verticais em vermelho mostram o códon ATG nativo e os retângulos hachurados mostram a matriz de leitura aberta. Para cada tipo de isoforma, os números acima dos sítios de fusão são os últimos pares de base no gene TMPRSS2 e o primeiro par de bases no gene ERG. A seta horizontal mostra o sítio do códon de início da tradução, sua localização no gene ERG é mostrada. Em vermelho, os ATGS nativos da tradução e em verde os ATGs não nativos da tradução. As setas horizontais de cor preta correspondem ao primeiro ATG da tradução do gene ERG. As setas horizontais vermelhas mostram o sítio de iniciação da proteína de fusão no mRNA tipo VI.

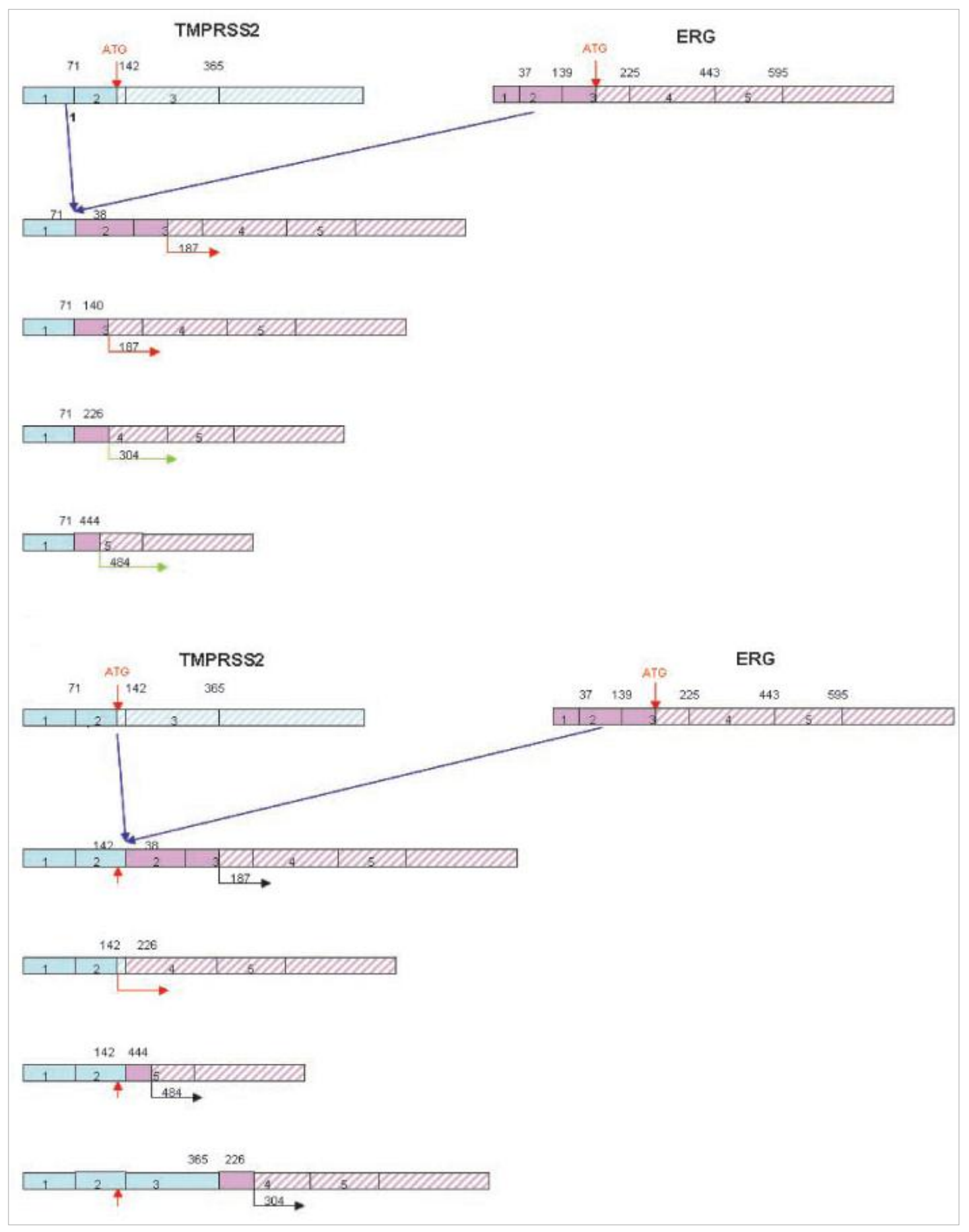




\section{OBJETIVOS}




\section{OBJETIVOS}

\subsection{OBJETIVO GERAL}

Caracterizar a frequência do gene de fusãoTMPRSS2/ERG em amostras de câncer de próstata de pacientes da Região de Ribeirão Preto, São Paulo, assistidos pelo Hospital das Clínicas da Faculdade de Medicina de Ribeirão Preto/USP.

\subsection{OBJETIVOS ESPECÍFICOS}

Caracterizar as amostras que apresentarem expressão do gene de fusão TMPRSS2/ERG quanto ao tipo de fusão envolvida.

Relacionar a presença da fusão e o tipo de isoforma envolvida com a idade, características histopatológica do tumor e de progressão da doença. 
3.JUSTIFICATIVA 


\section{JUSTIFICATIVA}

$\mathrm{O}$ mecanismo biológico do $\mathrm{CaP}$ ainda é pouco compreendido, apesar da sua importante incidência, como visto, e sua subsequente implicação clínica no seu prognóstico e na sua estratégia terapêutica.Como vários marcadores vêm sendo utilizados e nenhum marcador individual mostrou-se ideal, e considerando a heterogeneidade do CaP, é possível que a combinação de diversos biomarcadores possa fornecer melhores valores preditivos.

A descoberta das translocações cromossômicas, portanto, fornece subsídios para o entendimento do comportamento patológico dessa neoplasia, com prováveis aplicações para seu o diagnóstico, desenvolvimento de drogas, tratamentoe na elucidaçãodo seu mecanismo biológico subjacente.

Sendo assim, e se considerarmos que a maioria desses trabalhos em busca de biomarcadoressão realizados com populações de outros países, que possuem aporte genético distinto daquele verificado no Brasil, em nossa investigação trabalhamos com um grupo de pacientes de origem brasileira, cujo critério de seleção foi devidamente proposital a fim de analisar o percentual de pacientes com $\mathrm{CaP}$ pertencentes a essa "etnia" detectados como portadores de transcritos do rearranjo TMPRSS2-ERG. Essa pesquisa juntamente com outras com diferentes populações do país, possibilitam determinar o real significado clínico desse rearranjo frente ao seu percentual no país, podendo vir a nortear a vigilância ativa e a conduta terapêutica no Brasil. 
4.MATERIAIS E MÉTODOS 


\section{CASUÍTICA E MÉTODOS}

\subsection{TIPOS DE ESTUDO}

Trata-se de um estudo exploratório, quantitativo e de corte transversal (COLLIS J. \& HUSSEY R., 2005; MARTINS G.A, 1994; ROUQUAYROL M.Z \& ALMEIDA FILHO N., 2006).

Segundo os autores acima referidos, esse tipo de pesquisa descreve o

comportamento dos fenômenos. É usada para identificar e obter informações sobre características de um determinado problema ou questão. A pesquisa exploratória é realizada pela abordagem de um objeto de pesquisa quando há pouco ou nenhuma informação anterior sobre a temática proposta. O objetivo desse tipo de estudo é o de procurar padrões, ideias ou hipóteses, em vez de testar hipóteses ou confirmá-las. O método quantitativo envolve a coleta e análise de dados numéricos utilizando-se ou não de testes estatísticos.

Collins e Hussey (2005) definem estudo de corte transversal como uma metodologia positivista projetada para obter informações sobre variáveis em diferentes contextos, mas simultaneamente. É um instantâneo de uma situação em andamento.

\subsection{ASPECTOS ÉTICOS}

Tendo em vista o cuidado e o respeito ético aos participantes do estudo e, ainda, com base nas diretrizes regulamentadoras das pesquisas com seres humanos (BRASIL, Lei n¹96, 1996), o presente estudo foi encaminhado ao Comitê de Ética e Pesquisa da Faculdade de Medicina de Ribeirão Preto - USP, tendo sido aprovado sob o protocolo $\mathrm{n}^{\circ} 103555 / 2011$.

O projeto foi dispensado do Termo de Consentimento Livre e Esclarecido (TCLE) uma vez que os dados utilizados são oriundos de prontuários médicos nos quais é impossível precisar a localização dos pacientes e, também, porque não seria necessário e muito menos ético identificar os sujeitos envolvidos, que foram apenas nomeados pelas suas iniciais.

\subsection{CASUÍSTICA}

Foram utilizadas 76 amostras de tecido prostático provenientes de 
prostatectomias radicais de pacientes com CaP, realizadas entre os anos de 2007 e 2008 , oriundos do Hospital das Clínicas da Faculdade de Medicina de Ribeirão Preto da Universidade de São Paulo- HCFMRP-USP (com seguimento pós-operatório de 4 anos para a maioria dos pacientes, havendo perda de seguimento para alguns deles) que se encontravam armazenadas no Banco de Tumores Urogenitais do HCFMRP/USP. Essas amostras foram submetidas à microdissecção pelo Dr. Fabiano Pinto Saggioro (Setor de Patologia do Hospital das Clínicas de Ribeirão Preto) para verificação de positividade (feito no fragmento julgado representativo da neoplasia). Vinte fragmentos de próstata continham a neoplasia prostática de interesse e foram encaminhados para extração do RNA, obtenção dos respectivos cDNAs e avaliação dos mesmos.

O projeto BANCO DE TUMORES UROGENITAIS foi submetido ao Comitê de Ética da instituição (processo: 12375/2008), obtendo aprovação para o seu estabelecimento e desenvolvimento em 16/2/2009.

\subsection{ESTUDO CLÍNICO}

Realizamos revisão de prontuário de todos os pacientes a fim de estabelecer relação entre os dados pessoais, clínicos (pré/pós-operatório) e anatomopatológicos do tumor com a presença/ausência e o tipo de isoforma do rearranjo TMPRSS2/ERG para o prognóstico do $\mathrm{CaP}$. O critério de escolha das variáveis clínicas foi aquele que nos permitiu estabelecer relação das mesmas com a presença/ausência do gene de fusão em estudo, sendo esta relação já estudada por outros autores com outras populações (TOMLINS S.A. et al. 2008.). As variáveis selecionados foram: idade, etnia, grau de Gleason, análise do comprometimento da próstata, invasão de vesícula seminal e estadiamento (TNM).

\subsection{ESTUDO MOLECULAR}

O estudo molecular foi desenvolvido no Laboratório de Genética Molecular e Bioinformática do Hemocentro de Ribeirão Preto do HCFMRP/USP de responsabilidade do Professor Dr. Wilson Araújo da Silva Júnior pertencente ao Departamento de Genética do HCFMRP/USP. Sua finalidade foi avaliar a presença/ausência do rearranjo TMPRSS2/ERG em pacientes com CaP pertencentes a uma população brasileira. 


\subsection{PREPARAÇÃO DAS AMOSTRAS DE TECIDO PROSTÁtico PARA O ESTUDO MOLECULAR}

\subsubsection{Obtenção das amostras}

Os fragmentos de tecido prostático foram obtidos de pacientes com câncer de próstata, submetidos à prostatectomia radical. Os pacientes não foram expostos a qualquer tratamento prévio antes da cirurgia. As amostras de tecido fresco foram submetidas ao choque térmico em nitrogênio líquido com isopentano gelado. Em seguida foram mantidas em câmara fria em temperatura de $-80^{\circ} \mathrm{C}$ no Banco de Tumores Urogenitais do HCFMP/USP, até o momento da microdissecção.

\subsubsection{Microdissecção (MC) das amostras}

\subsubsection{Processamento histológico do material}

Os fragmentos de próstata foram encaminhados ao Setor de Patologia do HCFMRP/USP, mantidos em gelo seco. Foram fixados por 48 horas em formalina a $10 \%$ tamponada com fosfato de sódio monobásico e fosfato de sódio dibásico anidro, nas proporções de 4 e 6,5 g/l, lavados em água corrente durante 24 horas e mantidos em álcool a $70 \%$ por até 72 horas.

Em seguida, foram submetidos ao processador automático de tecidos (Leica EG1160, Alemanha), com desidratação por álcool e diafanização por xilol. O tecido foi incluído em parafina a $60^{\circ} \mathrm{C}$ em inclusor (Leica EG 1160 , Alemanha).

\subsubsection{Preparo das lâminas para MC}

Foram testados cortes histológicos com três espessuras (4, 5 e $6 \mu \mathrm{m})$ obtidos em micrótomo semi-automático (Leica RM 214, Alemanha). Para cada bloco de parafina a ser recortado, fez-se assepsia do micrótomo com álcool a 70\%, assim como troca de navalha, do parafilme e das luvas do técnico. Para distensão do corte usou-se banhomaria com água destilada (aproximadamente a $50^{\circ} \mathrm{C}$ ). As lâminas com os cortes histológicos foram mantidas em temperatura ambiente overnight para secar e, a seguir, coradas com azul de toluidina (Tabela 2). Atenção especial foi dada à etapa de desidratação durante a técnica de coloração, pois a presença de água no corte histológico impede a adesão adequada do fragmento histológico ao filme termoplástico, dificultando a leitura ao microscópio óptico. As lâminas ficaram sem lamínulas de 20 a 
30 minutos em temperatura ambiente antes do procedimento de MC. Cortes histológicos de cada amostra foram corados por hematoxilina e eosina (H-E) para análise morfológica de controle.

Tabela 3- Procedimentos de coloração das amostras para microdissecção.

\begin{tabular}{lcc}
\hline \multicolumn{1}{c}{ Etapas } & Soluções & Tempo \\
\hline Desparafinização & Xilol I & $2 \mathrm{~min}$ \\
\multirow{2}{*}{ Hidratação } & Xilol II & $2 \mathrm{~min}$ \\
& Etanol a 95\% & $1 \mathrm{~min}$ \\
Coloração & Etanol a 75\% & $1 \mathrm{~min}$ \\
& Água destilada & $30 \mathrm{~s}$ \\
Desidratação e Diafanização & Azul de toluidina a 0,5\% & Cobrir o corte \\
& & e lavar em seguida \\
& Etanol a 75\% & $30 \mathrm{~s}$ \\
& Etanol a 95\% & $30 \mathrm{~s}$ \\
& Etanol absoluto II & $30 \mathrm{~s}$ \\
& Etanol absoluto III & $1 \mathrm{~min}$ \\
& Xilol III & $5 \mathrm{~min}$ \\
& Xilol IV & $5 \mathrm{~min}$ \\
\hline
\end{tabular}

\subsubsection{Microdissecção}

O corte histológico foi localizado no centro da lâmina e fixado ao microscópio. Um suporte articulado ao microscópio se acoplou a um botão plástico transparente que possui um filme termoplástico em sua extremidade denominado cap (CapSureTM Macro LCM Caps LCM 0211, Arcturus Bioscience Mt. View, CA). Esse suporte transporta o cap para uma posição precisa sobre o tecido, alinhando-o à objetiva do microscópio. A imagem de interesse (células isoladas ou grupos celulares) é visualizada permitindo orientar a dissecção pelo patologista.

A base do microscópio é movida por um joystick para colocar a área de interesse no campo ótico. De acordo com a extensão da área a ser microdissecada, podem-se utilizar três opções de diâmetro do corte $(7,15$ e $30 \mu \mathrm{m})$. Ao final, o fragmento de interesse, contendo o foco de neoplasia é retirado do sistema com um suporte próprio e acoplado a um microtubo.

Foram microdissecadas 20 amostras com cerca de $15 \mu \mathrm{m}$ de diâmetro. O restante do tecido (bordas e tecido não alvo) permaneceu intacto na lâmina histológica. A morfologia do fragmento transferido foi preservada. Após coletar as áreas de interesse, o microtubo de $0,5 \mathrm{ml}$ foi mantido em suporte com gelo até o momento da extração. 


\subsection{ESTUDO MOLECULAR- ANÁLISE DA EXPRESSÃO GÊNICA RELATIVA AO REARRANJO TMPRSS2/ERG}

\subsubsection{Peso das amostras}

Primeiramente, os tubos contendo as amostras foram pesados e os respectivos pesos de cada tubo foram determinados em uma balança digital de alta precisão. Em seguida, cada amostra foi transferida para outro tubo vazio, previamente identificado, e o peso do tubo que continha a amostra foi verificado. Pela diferença entre o tubo contendo a amostra e o tubo vazio foi estabelecido o peso de cada amostra. Durante todo o procedimento as amostras permaneceram devidamente em gelo seco.

\subsubsection{Cálculo da quantidade de Trizol e Glicogênio}

Utilizamos o método do reagente tiocianato de guanidina-fenolclorofórmio TRIzol® (Invitrogen, USA) para a extração do RNA. Sua quantidade foi calculada de forma que para cada $10 \mathrm{mg}$ de tumor fossem acrescidos $800 \mu \mathrm{L}$ de TRIzol® $(10 \mu \mathrm{g} / \mu \mathrm{L})$.

Acrescentamos glicogênio, um coprecipitante de ácidos nucléicos, ao método. Ele não aumenta a precipitação do RNA, mas como ele precipita nas mesmas condições, forma um pellet visível, que facilita a manipulação da amostra. O cálculo para a quantidade utilizada seguiu a relação: a cada 10mg do tumor foram acrescidos $10 \mu \mathrm{L}$ de glicogênio $(10 \mu \mathrm{g} / \mu \mathrm{L})$.

\subsubsection{Extração de RNA total}

a. Maceração do tecido prostático

Posterior à pesagem, as amostras foram deixadas a temperatura ambiente, no interior de uma capela de fluxo laminar, por cerca de quatro minutos. Enquanto isso se prosseguiu com a limpeza do mixer (Brinkman Polytron, modelo PT 10/35) em soluções nas seguintes passagens: 
- $1^{\circ}$ - Água corrente (cerca de cinco a seis vezes);

- $2^{\circ}$ - Água destilada;

- $3^{\circ}$ - Etanol;

- $\quad 4^{\circ}$ - Etanol $60 \%$.

Para finalizar, a broca do mixer foi limpa utilizando-se uma solução com RNase e em seguida água Ultra Pure ${ }^{\mathrm{TM}}$ (Invitrogen) contendo DEPC (dietilpirocarbonato forte inibidor de RNAses). Com o auxílio de uma gase seca enxugou-se o restante de umidade na broca. Esse procedimento foi repetido todas as vezes que uma nova amostra foi manipulada. Também foi tomado cuidado quanto às vidrarias (submetidas à estufa em calor seco por doze horas a $180^{\circ} \mathrm{C}$ ) e os tubos de $15 \mathrm{~mL}$ utilizados para a maceração eram RNase free e estéreis.

Findados os quatro minutos, retirou-se o tubo contendo a amostra, adicionando-o $1 \mathrm{ml}$ de TRIzol ${ }^{\circledR}$, juntamente com todo o glicogênio calculado para o seu peso. Com o auxílio do polytron o fragmento foi macerado, e a intervalos rápidos foi alternando-se o TRIzol $^{\circledR}$ (de 1 em $1 \mathrm{ml}$ ) e a maceração, até completa dissociação do fragmento.

Após a maceração de todos os fragmentos, foram feitas quatro alíquotas de cada amostra em microtubos com $1 \mathrm{ml}$ cada, sendo que três dessas alíquotas foram armazenadas no freezer a $-80^{\circ} \mathrm{C}$ e 1 reservada para a extração subsequente.

\section{b. Extração do RNA total}

As alíquotas reservadas de cada um dos fragmentos foram centrifugadas por 15 minutos a temperatura de $4^{\circ} \mathrm{C}$ a $13.200 \mathrm{rpm}$ (rotações por minuto). Em seguida, no interior de uma capela de fluxo laminar, a fase aquosa foi descartada em um microtubo de $1,5 \mathrm{ml}$ vazio, adicionando a ele $200 \mu \mathrm{L}$ de clorofórmio e $500 \mu \mathrm{L}$ de isopropanol gelado. . O microtubo foi submetido a temperatura de $-80^{\circ} \mathrm{C}$ por uma hora. Essa mesma operação foi repetida para cada uma das amostras.

Aguardado esse tempo, a suspensão foi dispensada e centrifugada a temperatura de $4^{\circ} \mathrm{C}$, por mais 15 minutos, $13.200 \mathrm{rpm}$. Esse último processo foi repetido por mais uma vez. Por fim, ao descartar novamente a suspensão, foi tomado o cuidado de remover o possível de excesso de líquido restante e o tubo, referente a cada amostra. Em seguida, foi invertido e deixado secar, a fim de se obter um pellet de RNA. Esse pellet foi ressuspendido em 10 a $20 \mu \mathrm{L}$ de água Ultra Pure ${ }^{\mathrm{TM}} \mathrm{DPEC}$, pré-aquecida a $70^{\circ} \mathrm{C}$ por 
cerca de 10 a 60 minutos e depois armazenado a $-80^{\circ} \mathrm{C}$.

\subsubsection{Determinação da qualidade do RNA}

Após a extração, cada amostra foi submetida à análise pelo espectofotômetro NanoDrop ${ }^{\circledR} 1000$ (BiophoAtometer-Eppendorf®) para verificação de sua concentração e razão. Para tal, utilizou-se $1 \mu \mathrm{L}$ da amostra e água Ultra Pure ${ }^{\mathrm{TM}}$ DPEC (a mesma solução que o RNA está diluído) como branco em uma absorbância de 260 nm (nanômetros). Esse processo permite avaliar a pureza da extração em relação à presença de proteínas contaminantes (a relação de 260/280 nm para RNA deve estar acima de 2). Em seguida, O RNA foi ressuspendido em água Ultra Pure ${ }^{\mathrm{TM}}$ DPEC para um volume de $150 \mu \mathrm{L}$ (diluição - 1:10) para sua utilização nos processos subsequentes.

Para avaliação da integridade do RNA, checamos $2 \mu \mathrm{L}$ de RNA (diluição - 1:10 em água Ultra Pure ${ }^{\mathrm{TM}}$ DPEC, corresponde a uma quantidade de, aproximadamente, 200ng de RNA) das amostras em gel de agarose a 1,2\% TAE (Tampão Tris-AcetatoEDTA- ácido etilenodiamino tetra-cético), como especificado no item 4.6.7.

\subsubsection{Transcrição reversa (RT-PCR)}

Utilizamos a reação de amplificação da cadeia da polimerase (PCR) por meio da transcrição reversa (RT-PCR) com a finalidade de obter cDNA a partir do RNA extraído. Para evitar que uma eventual contaminação por DNA genômico interfira nos resultados, todas as amostras de RNA total foram tratadas com DNAse antes de serem submetidas ao RT-PCR.

A reação foi procedida conforme as instruções do protocolo do kit High Capacity DNA Reverse Transcription (Applyed Biossystem, USA). Em um microtubo de 1,5ml, mantido em gelo, foram acrescentados os reagentes (Tabela 4). Com o auxílio de uma pipeta, $49 \mu \mathrm{L}$ dessa preparação foi colocado em cada microtubo (para termociclador), e em seguida, acrescentou-se $1 \mu \mathrm{L}$ de RNA (diluição - 1:5, em água Ultra Pure ${ }^{\mathrm{TM}}$ DPEC) referente a cada uma das amostras. Após esse procedimento, as amostras foram transferidas para o gelo e imediatamente levadas ao termociclador.

Tabela 4 - Relação dos reagentes utilizados na reação de RT-PCR e as suas respectivas quantidades utilizadas para a realização de uma reação. 


\begin{tabular}{cc}
\hline Reagentes & Quantidade para 1 reação $(\mu \mathrm{L})$ \\
\hline Tampão 10X & 05,00 \\
Random primer & 05,00 \\
Enzima Multscribe & 03,00 \\
dNTPs* & 02,00 \\
Água Ultra Pure ${ }^{\mathrm{TM}}$ DPEC & 34,00 \\
Total & 49,00 \\
\hline
\end{tabular}

*(dNTPs) Desoxinucleotídeos.

A reação foi submetida a $25^{\circ} \mathrm{C}$ por dez minutos, a $37^{\circ} \mathrm{C}$ por duas horas e a $4^{\circ} \mathrm{C}$ por tempo indeterminado (fim da reação).

Seguindo a padronização do nosso laboratório, como controle interno da reação de RT-PCR utilizamos a amplificação do gene constitutivamente expresso da $\beta$-actina (Tabela 5) para testar a integridade das amostras de cDNA e o sucesso da reação de transcrição reversa.

Tabela 5 - Oligonucleotídeos iniciadores (Foward - F e Reverse - R) do gene da $\beta$ actina.

\begin{tabular}{|c|c|c|c|}
\hline$\overline{\beta \text {-actina }}$ & Sequência 3'-5' & Produto $\left(\mathrm{pb}^{*}\right)$ & $\operatorname{Tm}\left({ }^{\circ} \mathrm{C}\right)$ \\
\hline $\mathrm{F}$ & AGCGAGCATCCCCCAAAGTT & 285 & \\
\hline $\mathrm{R}$ & GGGCACGAAGGCTCATCATT & & \\
\hline
\end{tabular}

*pb- pares de base

A PCR para amplificação foi realizada conforme o protocolo do kit (Tabela 6). Os reagentes foram adicionados a um tubo de $1,5 \mathrm{ml}$ livre de RNase, mantido em gelo, e $26,25 \mu \mathrm{L}$ foram transferidos para tubos de $0,2 \mu \mathrm{L}$ livre de RNase (previamente identificados com o número de cada amostra). Juntou-se $2 \mu \mathrm{L}$ do RNA (diluição - 1:5 da solução estoque) de cada amostra a cada um desses tubos.

Tabela 6 - Relação dos reagentes utilizados na reação de PCR para amplificação do gene da $\beta$-actina e as suas respectivas quantidades utilizadas para a realização de uma reação.

\begin{tabular}{cc}
\hline Reagentes & Quantidade para 1 reação $(\mu \mathrm{L})$ \\
\hline Tampão Tween & 02,50 \\
dNTPs* & 02,00
\end{tabular}




\begin{tabular}{cc} 
Primer $(\mathrm{F}) * *$ & 01,50 \\
Primer (R)*** & 01,50 \\
EnzimaAmpliTaq & 00,25 \\
Gold(Applied Biossystem) & \\
Água Ultra Pure ${ }^{\mathrm{TM}}$ DPEC & 12,50 \\
Total & 26,25 \\
\hline *(dNTPs)Desoxinucleotídeos, **Oligonucleotídeo iniciador "sense", \\
***Oligonucleotídeo iniciador "antissense
\end{tabular}

Em seguida, as amostras foram submetidas à incubação a $94^{\circ} \mathrm{C}$ por 6 minutos em termociclador Veriti (ApplyedBiossystem, USA), seguida pelas incubações cíclicas descritas: desnaturação: $94^{\circ} \mathrm{C}$ por 40 segundos; anelamento: $68^{\circ} \mathrm{C}$ por um minuto e extensão: $72^{\circ} \mathrm{C}$ por 1 minuto. Após 28 ciclos, as amostras foram submetidas à temperatura de $72^{\circ} \mathrm{C}$ por 10 minutos, e em seguida a $4^{\circ} \mathrm{C}$ e mantidas nessa temperatura (fim da reação).

Uma alíquota do produto $(4 \mu \mathrm{L})$ foi avaliada qualitativamente por eletroforese em gel de agarose diluída a 1,2\% em TAE (item 4.6.7). Espera-se que se forme uma banda única correspondente a amplificação do gene da $\beta$-actina.

\subsubsection{Reação em cadeia da polimerase (PCR) para amplificação do rearranjo TMPRSS2/ERG}

A PCR foi realizada para isolar e amplificar o rearranjo TMPRSS2/ERG de cada paciente. Foram utilizadas sequências de oligonucleotídeos iniciadores ("primers") obtidas de TOMLINS S.A. et al. (2005), relacionados na Tabela 7.

Tabela 7 - Oligonucleotídeos iniciadores (F e R) do rearranjo TMPRSS2/RG.

\begin{tabular}{cccc}
\hline TMPRSS2/ERG & Sequência 3'-5' & Produto (pb) & Tm ( $\left.{ }^{\mathbf{0}} \mathbf{C}\right)$ \\
\hline F & CAGGAGGCGGAGGCGGA & 285 \\
R & CGCGTTGTAGCTGGGGGTGAG & \\
\hline
\end{tabular}

(pb) pares de base, (F) Foward, (R) Reverse, Fonte: Tomlins S.A. et al., 2005.

Os reagentes (Tabela 8) foram adicionados a um tubo de 1,5ml e uma alíquota de $28 \mu \mathrm{L}$ da reação foi transferida, com auxílio de uma pipeta, para tubos de $0,2 \mathrm{ml}$ (previamente identificados), em seguida acrescentamos $2 \mu \mathrm{L}$ de RNA (diluição - 1:5 da 
solução estoque, em água Ultra Pure ${ }^{\mathrm{TM}} \mathrm{DEPC}$ ) de cada amostra.

A reação foi submetida a: 30 ciclos a $94^{\circ} \mathrm{C}$ por seis minutos (ativação da enzima); $65^{\circ} \mathrm{C}$ por um minuto (anelamento dos oligonucleotídeos iniciadores) e $72^{\circ} \mathrm{C}$ por um minuto (extensão da fita pela ação da enzima). Para finalizar mais um minuto a $72^{\circ} \mathrm{C}$ (extensão final) e em seguida a $4^{\circ} \mathrm{C}$ por tempo indeterminado (fim da reação). Uma alíquota do produto $(4 \mu \mathrm{L})$ foi avaliada qualitativamente por gel de agarose diluída a $1,5 \%$ em TAE.

Tabela 8 - Relação dos reagentes utilizados na reação de PCR para amplificação do gene da $\beta$-actina e as suas respectivas quantidades utilizadas para a realização de uma reação.

\begin{tabular}{cc}
\hline Reagentes & Quantidade para 1 reação $(\mu \mathrm{L})$ \\
\hline Tampão 10x & 03,00 \\
dNTPs* $^{*}$ & 02,00 \\
MgCl$_{2} * *$ & 01,50 \\
Primer (F)*** & 01,50 \\
Primer (R)**** & 01,50 \\
EnzimaAmpliTaq Gold & 00,25 \\
(AplliedBiossystem) & \\
Água Ultra Pure ${ }^{\mathrm{TM}}$ DPEC & 18,25 \\
Total & 28,00 \\
\hline
\end{tabular}

$*(\mathrm{dNTPs})$ Desoxinucleotídeos, ** $\left(\mathrm{MgCl}_{2}\right)$ Cloreto de magnésio,

***Oligonucleotídeo iniciador "sense" do gene TMPRSS2/ERG, ****

Oligonucleotídeo iniciador "antissense" do gene TMPRSS2/ERG.

\subsection{Eletroforese em gel de agarose}

Para confecção do gel de agarose a 1,2\%, utilizamos 1,2g de agarose UltraPure $^{\mathrm{TM}}$ (Invitrogen, EUA) em 100ml de TAE (40 mM de Tris-acetato e $2 \mathrm{mM}$ de ácido etilenodiaminotetracético). Essa mistura foi levada ao micro-ondas até completa fusão da agarose. Após seu esfriamento, $1 \mu \mathrm{L}$ de brometo de etídio UltraPure $^{\mathrm{TM}}$ (Invitrogen, EUA) a $0,5 \mu \mathrm{g} / \mathrm{ml}$ foi adicionado, e a agarose fundida foi colocada em um molde até que se solidificasse.

Uma alíquota do RNA total e dos produtos das PCRs (especificada nos itens anteriores para cada um) foi homogeneizada com $5 \mu \mathrm{L}$ do tampão de corrida $(0,25 \%$ de azul de bromofenol, $0,25 \%$ de xileno cianol, $30 \%$ de glicerol) e submetida à migração 
sob corrente constante de 90 Volts por cerca de 40minutos (Figura 9). O marcador de peso molecular LowDNA Mass ${ }^{T M}$ "Ladder" (Invitrogen, EUA) de $1 \mathrm{~kb}$ foi utilizado como referência para avaliar o tamanho dos fragmentos.

\subsubsection{Fotodocumentação do gel}

Utilizamos o sistema de fotodocumentação de gel de eletroforese em tempo real MiniBis Pro (DNR Bio-Imagen Systems), para visualizar e armazenar imagens de todos os géis confeccionados neste estudo. O sistema é acoplado sobre uma gaveta intercambiável que acomoda um transiluminador UV ou visível. As imagens foram armazenadas e analisadas em um computador acoplado ao sistema, por um software de análise, o GelQuant (DNR Bio-Imagen Systems). Ele detecta automaticamente as bandas, tamanhos de fragmentos e o peso molecular, salva e analisa, bem como possibilita girar e inverter o gel, ajustar nitidez, brilho, correção gama e redução de background. Os dados exportados são compatíveis com formato Excel e Star Office.

\subsubsection{Reação de PCR para verificação da qualidade das amostras enviadas ao sequenciamento}

A reação de PCR foi empreendida para verificar se as amostras estavam aptas para serem enviadas ao sequenciamento, pois a sua qualidade é fundamental para o sequenciamento. Foram utilizadas as mesmas sequências de oligonucleotídeos iniciadores utilizadas para a amplificação do rearranjo TMPRSS2/ERG (Item 5.2.3.3).

Os reagentes para a reação de amplificação (Tabela 9) foram misturados à parte em suas respectivas quantidades, proporcionais ao número de amostras e mais um controle (mistura sem a adição de RNA). Uma alíquota de $15 \mu \mathrm{L}$ dessa mistura foi transferida a microtubos (previamente identificados) e em seguida adicionado o volume de $2 \mu \mathrm{L}$ de cDNA de cada amostra.

Tabela 9 - Relação dos reagentes utilizados na reação de PCR para verificação da qualidade do cDNA do gene de fusão TMPRSS2/ERG enviadas ao sequenciamento do cDNA do gene de fusão TMPRSS2/ERG e as suas respectivas quantidades utilizadas para a realização de 1 reação.

\begin{tabular}{cc}
\hline Reagentes & Quantidade para 1 reação $(\mu \mathrm{L})$ \\
\hline Tampão 10X & 01,50 \\
dNTPs* & 01,50
\end{tabular}




$\begin{array}{cc}\text { Primer }(\mathrm{F})^{* * *} & 00,80 \\ \text { Primer }(\mathrm{R})^{* * *} & 00,80 \\ \mathrm{MgCl}_{2} * * * * & 00,45 \\ \text { EnzimaAmpliTaq Gold } \text { Fi*** }^{* *} & 00,20 \\ \text { Água Ultra Pure' } & 09,75 \\ \text { Total } & 15,00\end{array}$

*(dNTPs) Desoxinucleotídeos, **Oligonucleotídeo iniciador "sense" do gene TMPRSS2/ERG, ***Oligonucleotídeo iniciador "antissense" do gene TMPRSS2/ERG, **** $\left(\mathrm{MgCl}_{2}\right)$ Cloreto de magnésio,*****(Applied Biossystem, USA).

A reação foi submetida a: a $95^{\circ} \mathrm{C}$ por três minutos e 35 ciclos a $95^{\circ} \mathrm{C}$ por 40 segundos (ativação da enzima); $65^{\circ} \mathrm{C}$ por 40 segundos (anelamento dos oligonucleotídeos iniciadores) e $72^{\circ} \mathrm{C}$ por 55 segundos (extensão da fita pela ação da enzima). Para finalizar mais cinco minuto a $72^{\circ} \mathrm{C}$ (extensão final) e em seguida a $4^{\circ} \mathrm{C}$ por tempo indeterminado (fim da reação). Uma alíquota do produto $(4 \mu \mathrm{L})$ foi avaliada qualitativamente por gel de agarose diluída a 1,5\% em TAE, para verificar se havia apenas a banda correspondente ao rearranjo TMPRSS2/ERG na amplificação.

\subsubsection{Quantificação do produto de PCR enviado para sequenciamento}

Após a verificação da qualidade da PCR para amplificação do rearranjo, cada amostra foi submetida à análise do equipamento do Nanodrop 1000 Spectrophotometer (Thermo Fisher ScientificInc) (Figura 8- Biophotometer-Eppendorf®)para verificação de sua concentração (100 a $200 \mathrm{ng} / \mu \mathrm{L})$ e razão, utilizando o mesmo procedimento do item 5.2.3.5.

\subsection{SEQUENCIAMENTO}

\subsubsection{Reação de sequenciamento}

Depois de feitas as análises qualitativas e quantitativas do cDNA, a reação do sequenciamento foi realizada utilizando o BigDye® Terminator v3.1 Cycle Sequencing Kit (Apllied Biossystem, USA) e as reações foram analisadas pelo software SequencingAnalysis 5.2 (AplliedBiossystem, Foster City, CA). 
A reação foi feita para um volume final de $10 \mu \mathrm{L}$ (Tabela 10). As condições de reação foram: $96^{\circ} \mathrm{C}$ por um minuto e 25 ciclos a $96^{\circ} \mathrm{C}$ por 10 segundos (desnaturação); $50^{\circ} \mathrm{C}$ por cinco segundos (anelamento) e $60^{\circ} \mathrm{C}$ por quatro minutos (extensão). A reação foi mantida a $4^{\circ} \mathrm{C}$ até a etapa de precipitação.

Tabela 10 - Relação dos reagentes para a reação de sequenciamento do cDNA do gene de fusão TMPRSS2/ERG.

\begin{tabular}{cc}
\hline Reagentes & Quantidade para 1 reação $(\mu \mathrm{L})$ \\
\hline PremixReadyReaction & 01,00 \\
Tampão de sequenciamento 2,5X & 02,00 \\
Água Ultra Pure ${ }^{\mathrm{TM}}$ DPEC & 04,00 \\
Primer (F)* & 01,00 \\
Primer $(\mathrm{R})^{* *}$ & 01,00 \\
Produto de PCR $(100 \mathrm{ng} / \mu \mathrm{L})^{* * *}$ & 01,00 \\
Total & 10,00 \\
\hline
\end{tabular}

*Oligonucleotídeo iniciador "sense" do gene TMPRSS2/ERG,

**Oligonucleotídeo iniciador "antissense" do gene TMPRSS2/ERG. Os primers para a amplificação do rearranjo TMPRSS2/ERG foram diluídos $(2.5 \mu \mathrm{M}) \mathrm{em}$ água Ultra Pure ${ }^{\mathrm{TM}} \mathrm{DPEC}$, a partir do estoque, momentos antes da reação, para garantia de sua qualidade. $* * *$ do item 4.6.8.

\subsubsection{Precipitação}

A precipitação dos produtos da PCR para sequenciamento foi feita em isopropanol para um volume final de $10 \mu \mathrm{L}$. Primeiramente, acrescentamos $30 \mu \mathrm{L}$ de água Mili-Q e $60 \mu \mathrm{L}$ de isopropanol $(100 \%)$ a cada amostra contida na placa para o sequenciamento, permanecendo em repouso por 20 minutos. Em seguida, centrifugamos as placas por 45 minutos a 4000rpm. Após a centrifugação, o sobrenadante, invertendo removido e adicionamos $200 \mu \mathrm{L}$ de etanol $70 \%$. Novamente a placa foi submetida à centrifugação por 20 minutos a 4000rpm. O etanol foi completamente removido, tomando o cuidado de inverter a placa e submetê-la a um spin (qualquer resíduo pode resultar em manchas fluorescentes na análise do sequenciamento). A placa foi seca em estufa e, em seguida, mantida envolta em papel alumínio em temperatura ambiente.

Para a corrida foi utilizado o aparelho ABI 3130 Genetic Analyser (Applied Biossystem, USA).

\subsubsection{Análise do sequenciamento}


Os cromatogramas gerados pelo sequenciador ABI 3130 Genetic Analyser são compactados, sendo assim procedemos com a descompactação dos mesmos através do software Winzip ${ }^{\circledR}$, versão 15.0, disponível no site: http://www.winzip.com/index.htm. Em seguida, eles foram analisados pelo software Chromas, versão 2.33, disponível para download no site: http://www.technelysium.com.au/chromas.html. A transferência foi feita em modo FASTA.

A determinação do número de pares de bases do rearranjo encontrado foi feita através do acesso ao GeneBank: TMPRSS2 - NM_005656 e ERG - Nm_004449. 
5. RESULTADOS 


\section{RESULTADOS}

\subsection{Análise molecular das amostras}

\subsubsection{Microdissecção das amostras}

Solicitamos o envio das amostras armazenadas no Banco de Tumores Urogenitais do HCFMRP/USP para o Setor de Patologia do HCFMRP/USP. Dos 76 fragmentos avaliados pelo Dr. Fabiano Pinto Saggioro, 20 foram representativos para a neoplasia da próstata e enviados ao nosso laboratório para análise molecular.

\subsubsection{Peso das amostras de tumor}

Os fragmentos prostáticos contendo o adenocarcinoma foram submetidos à pesagem, revelando que os mesmos apresentaram variabilidade de peso entre si, não ultrapassando a variação de 60mg (30mg a 90mg) (Tabela 11).

Tabela 11 - Pesagem dos fragmentos de tumor da próstata microdissecados.

\begin{tabular}{cccc}
\hline Paciente & $\begin{array}{c}\text { Peso total } \\
(\mathrm{g})\end{array}$ & $\begin{array}{c}\text { Peso do microtubo } \\
(\mathrm{g})\end{array}$ & $\begin{array}{c}\text { Peso da amostra } \\
(\mathrm{mg})\end{array}$ \\
\hline 1 & 1,06 & 1,00 & 60,00 \\
2 & 1,10 & 1,05 & 50,00 \\
3 & 1,08 & 1,05 & 50,00 \\
4 & 1,08 & 1,05 & 30,00 \\
5 & 1,04 & 1,00 & 40,00 \\
6 & 1,05 & 0,97 & 80,00 \\
7 & 1,03 & 0,99 & 40,00 \\
8 & 1,02 & 0,98 & 40,00 \\
9 & 1,07 & 1,10 & 60,00 \\
10 & 1,06 & 0,99 & 70,00 \\
11 & 1,03 & 1,00 & 30,00 \\
12 & 1,07 & 0,98 & 90,00 \\
13 & 1,07 & 0,99 & 80,00 \\
14 & 1,15 & 1,09 & 60,00 \\
15 & 1,07 & 0,99 & 80,00 \\
16 & 1,02 & 0,95 & 70,00 \\
17 & 1,04 & 0,98 & 60,00 \\
18 & 1,01 & 0,95 & 60,00 \\
19 & 1,06 & 0,97 & 70,00 \\
20 & 1,06 & 0,99 & 70,00 \\
\hline
\end{tabular}

* Peso do microtubo e amostra. 


\subsubsection{Extração}

Como não houve uma variação significativa de peso entre as amostras, optamos por utilizar a mesma quantidade de TRIzol $^{\circledR}$ para todas elas, e verificamos que não houve interferência na qualidade da extração (Figura 7). O pellet de RNA resultante foi ressuspendido em $20 \mu \mathrm{L}$ de água Ultra Pure ${ }^{\mathrm{TM}}$ DPEC e armazenado em freezer a $-80^{\circ} \mathrm{C}$ para as análises subsequentes.

\subsubsection{Verificação da qualidade das amostras}

Após a extração do RNA total, verificamos que as concentrações dos mesmos em cada amostra se mantiveram entre 667 e $2.328 \mathrm{ng} / \mu \mathrm{L}$ (Tabela 12). A leitura por espectrofotometria de absorbância do comprimento de onda de $260 \mathrm{~nm}\left(\mathrm{~A}_{260}\right)$ apresentou uma razão $A_{260} / A_{280}$ que variou de 1,72 a 1,88 . Como a $A_{260} / A_{280} \geq 2,00$ não foi atendida, optamos por utilizar inibidor de RNase $(1,0 \mathrm{U} / \mu \mathrm{L})$ nas reações de PCR e RTPCR a fim de evitar que uma possível contaminação por proteínas, como RNases, pudesse interferir na concentração e qualidade do RNA.

Tabela 12 - Relação entre os pacientes e a concentração de RNA presente em suas respectivas amostras de tumor.

\begin{tabular}{cccc}
\hline Paciente & $\begin{array}{c}\text { Concentração } \\
\text { de RNA }(\mathrm{ng} / \mu \mathrm{L})\end{array}$ & $\mathrm{A}_{260} / \mathrm{A}_{280}$ & $\begin{array}{c}\text { *Quantidade de } \\
\text { RNA }(\mu \mathrm{g})\end{array}$ \\
\hline 1 & 2.328 & 1,86 & 34,92 \\
2 & 1.935 & 1,82 & 29,02 \\
3 & 1.028 & 1,80 & 15,42 \\
4 & 942 & 1,76 & 14,13 \\
5 & 1.062 & 1,85 & 15,93 \\
6 & 1.021 & 1,80 & 15,31 \\
7 & 724 & 1,79 & 10,86 \\
8 & 667 & 1,88 & 10,00 \\
9 & 1.027 & 1,78 & 15,40 \\
10 & 1.611 & 1,88 & 24,16 \\
11 & 704 & 1,72 & 10,56 \\
12 & 1.832 & 1,84 & 27,48 \\
13 & 676 & 1,75 & 10,14 \\
14 & 1.713 & 1,76 & 25,69 \\
15 & 904 & 1,78 & 13,56 \\
16 & 1.290 & 1,87 & 19,35 \\
17 & 1.300 & 1,83 & 19,30 \\
18 & 975 & 1,77 & 14,62 \\
19 & 1230 & 1,87 & 18,45 \\
20 & 1035 & 1,86 & 15,52 \\
\hline
\end{tabular}

*Volume da solução estoque de RNA - $150 \mu \mathrm{L} /$ Diluição - 1:10. 
Avaliamos a integridade do RNA em gel de agarose a 1,2\% TAE exposto à luz UV. O perfil eletroforético dos pacientes 1 e 2, foi utilizado como modelo (Figura 7). $\mathrm{Na}$ primeira canaleta utilizamos para a corrida um RNA degradado para efeito de comparação. Já na segunda e terceira canaletas, verificam-se dois padrões de banda, condizentes às subunidades dos RNAs ribossômicos $28 \mathrm{~S}$ e $18 \mathrm{~S}$, em uma proporção de $2: 1$, respectivamente, o que indica que o RNA extraído se encontra intacto.

Figura 7- Gel de agarose a $1,2 \%$ mostrando o perfil eletroforético do RNA total extraído. (PM) Peso molecular, (D) RNA degradado, (1) Paciente 1 e (2) Paciente 2. As setas do lado esquerdo indicam as bandas referentes ao marcador molecular, e as setas do lado direito referem-se aos RNAs ribossômicos $18 \mathrm{~S}$ e $28 \mathrm{~S}$.

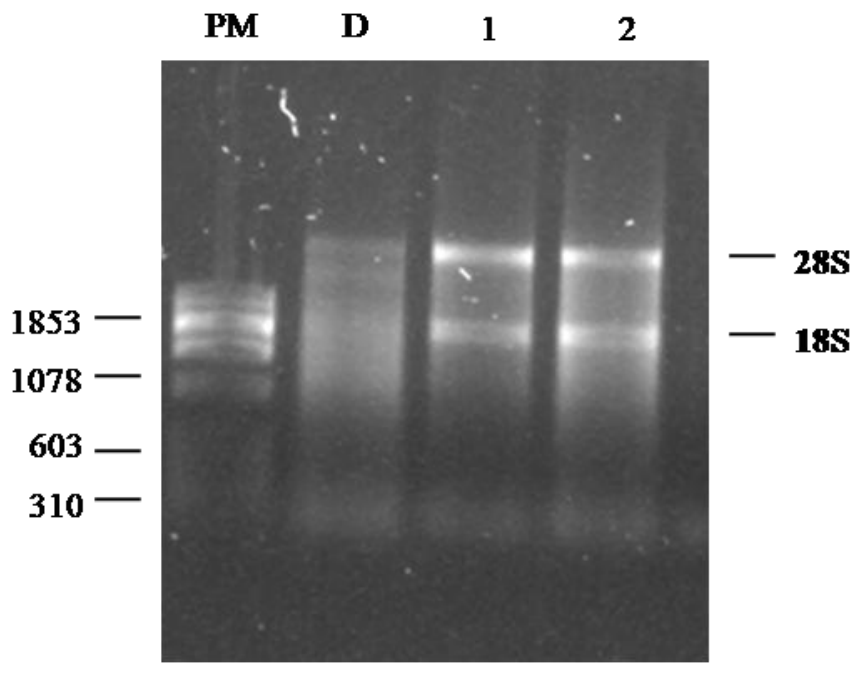

\subsubsection{Rearranjo TMPRSS2/ERG}

Uma vez obtido o RNA total, ele foi reversamente transcrito, servindo como molde para a síntese de cDNA. Para verificar a qualidade dessa síntese, realizamos a amplificação do gene da $\beta$-actina. Os fragmentos amplificados pela reação de PCR foram submetidos à eletroforese em gel de agarose 1,2\% TAE e visualizados em um transiluminador com luz UV (Figura 8). A análise da imagem resultante revelou que houve amplificação de apenas uma banda de, aproximadamente, 285 pb, correspondente ao fragmento do gene $\beta$-actina, comprovando o sucesso da reação de RT-PCR.

Certificada a garantia da qualidade do cDNA, prosseguimos com a amplificação do gene de fusão TMPRSS2/ERG por meio de uma reação em cadeia da polimerase. 
Submetemos a reação final à eletroforese em gel de agarose 1,2\% TAE e sua visualização demonstrou um perfil eletroforético correspondente a uma única banda de, aproximadamente, 720 pb em 7 dos 20 pacientes em análise (Figura 8). Esse resultado mostra que $35 \%$ das amostras continham o rearranjo TMPRSS2/ERG, e que por apresentarem um fragmento de tamanho muito próximo, possivelmente, pertenceriam a um mesmo tipo de isoforma desse rearranjo.

Figura 8 - Gel de agarose 1,2\% TAE, mostrando o resultado da amplificação pela PCR para o rearranjo TMPRSS2/ERG. Sua amplificação foi evidenciada nos pacientes de números 01, 08, 09, 12, 14, 15 e 18 . A seta do lado direito mostra o peso molecular referente à amplificação do fragmento correspondente ao rearranjo TMPRSS2/ERG $(\sim 720 \mathrm{pb})$.

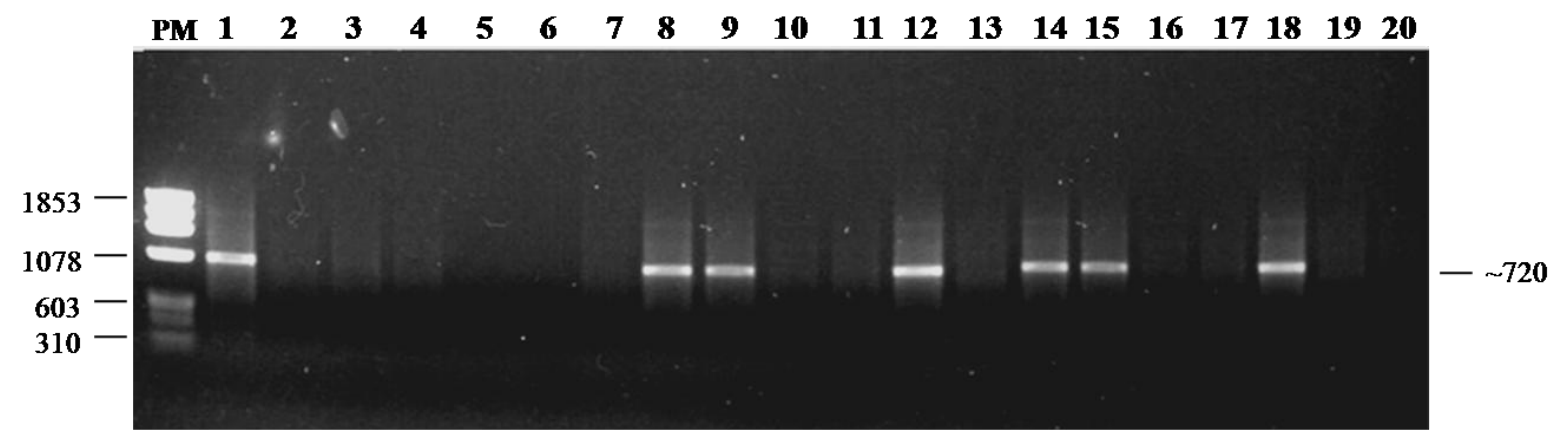

\subsubsection{Sequenciamento}

A fim de determinarmos a que tipo de isoforma do rearranjo TMPRSS2/ERG corresponderiam os fragmentos obtidos, procedemos com o sequenciamento das amostras positivas.

O resultado foi analisado, utilizando o software Chromas, versão $2.33 \mathrm{e}$ confirmou a nossa hipótese, todas as amostras portadoras do rearranjo pertenciam ao mesmo tipo de isoforma (Figura 9), que analisadas, foram identificadas como pertencentes ao tipo III, como estabelecido por WANG et al. (2006). As sequências utilizadas para análise estão depositadas no banco de dados do GenBank, do NCBI, com os números de acesso NM_005656 para o gene TMPRSS2 e NM_004449 para o gene $E R G$. 
Figura 9 - Esquema ilustrando a estrutura da isoforma do tipo III do rearranjo TMPRSS/ERG a partir do sequenciamento. Na porção superior de cada quadrante, a sequência de nucleotídeos e, na porção inferior, o cromatograma correspondente. Em evidência, a região na qual se liga o primer (PF) e a porção de cada um dos genes participantes envolvidos no rearranjo. Nos retângulos em azul, os éxons envolvidos de cada gene. No segundo cromatograma, observa-se o sítio de início da transcrição (retângulo) no éxon 4 do gene $E R G$. A reta vertical em azul limita a região envolvida de cada um dos genes no rearranjo, e a reta vertical vermelha delimita os éxons do gene $E R G$.
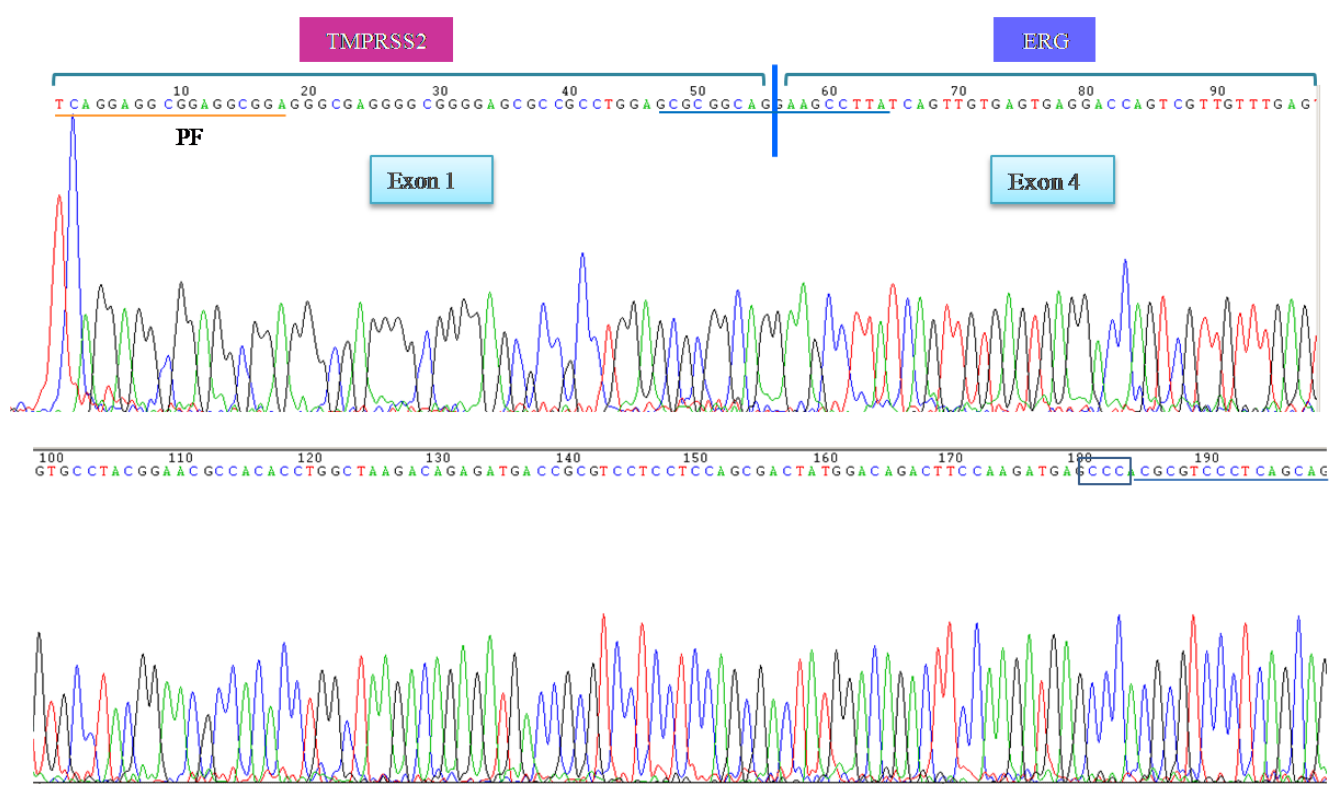

ERG

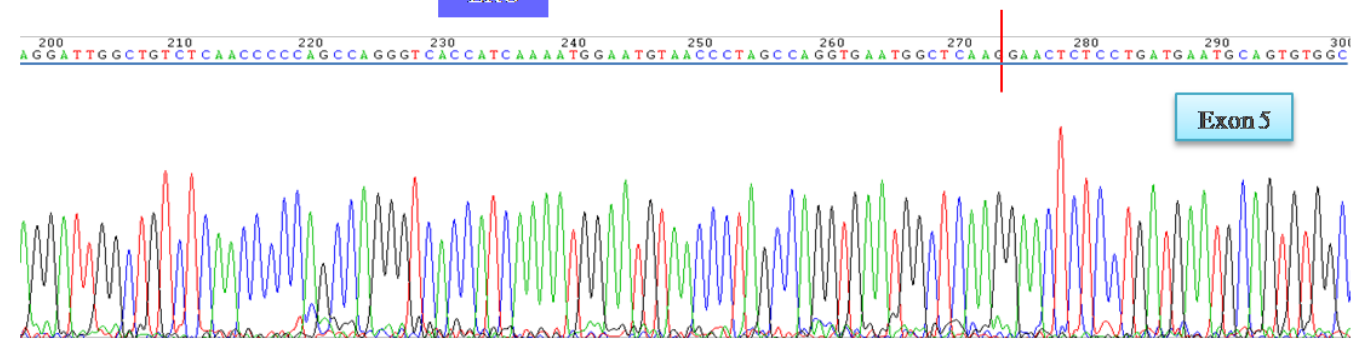

CAAAGGCGGGAAGATGGTGGGCAGCCCAGACACCGTTGGGATGAACTACGGCAGCTACATGGAGGAGAAGC 330 ACATGCCACCCCCAAACATTGACCACGA 3000
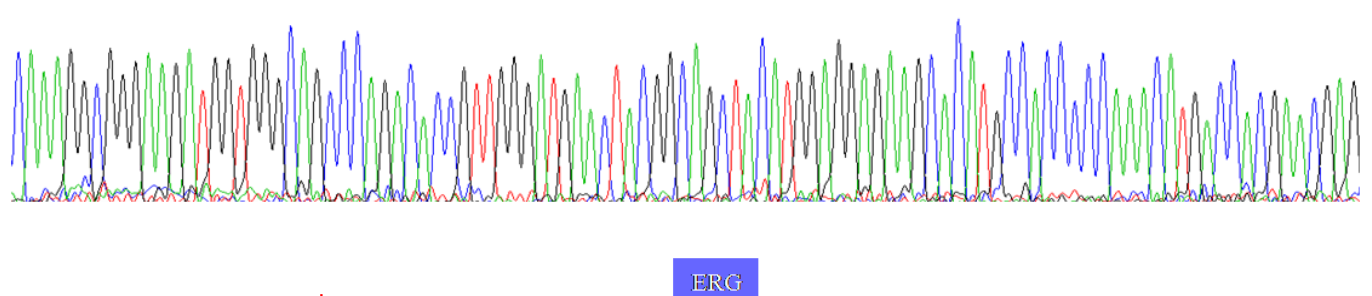

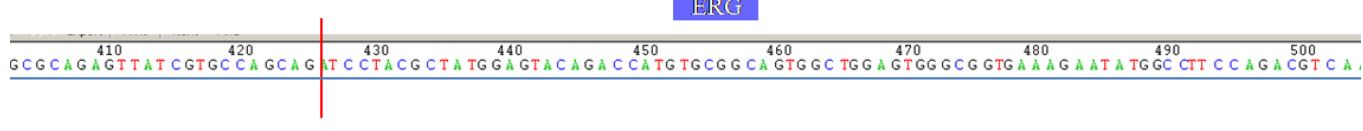

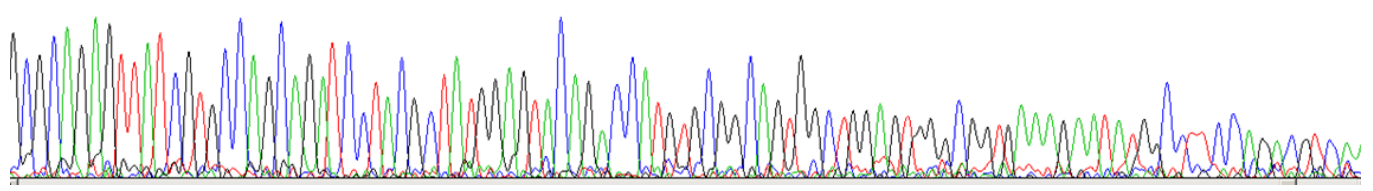




\subsection{Análise clínica (Prontuário médico)}

Essa análise teve por objetivo pesquisar dados clínicos que sustentassem a hipótese de correlação entre a presença ou ausência do rearranjo TMPRSS2/ERG com o diagnóstico e prognóstico do CaP.

Sendo assim, coletamos dados anatomopatológicos (Grau de Gleason e estadiamento do $\mathrm{CaP}$ ) da ressecção da próstata e dados clínicos dos sujeitos de pesquisa, tais como, idade, recorrência de PSA, invasão ou não da vesícula seminal, comprometimento prostático e ano da cirurgia. Dados a respeito da etnia dos pacientes não puderam ser coletados, devido à falta de critérios científicos e dados históricos que possibilitassem sua determinação. Apenas pode se afirmar que todos os participantes do estudo são residentes no Brasil e foram atendidos no HCFMRP-USP. A localização específica desses participantes não foi objeto de pesquisa.

Uma característica comum a todos os sujeitos foi a identificação histopatológica de adenocarcinoma acinar usual da próstata. Outra característica predominante foi a ausência de invasão de vesícula seminal (VS) até o momento da ressecção prostática. Apenas um dos pacientes apresentou invasão de VS, especificamente, a VS direita, não sendo possível determinar, através do prontuário médico, se ocorreu antes ou após a ressecção. Entretanto, verificou-se grande variabilidade das demais características clínicas entre os pacientes (Tabela 13).

Como valor prognóstico independente, observamos o GG cujo valor fornece uma análise da extensão do tumor e possível invasão extra-prostática. Os pacientes que apresentam tumores, cujo GG foi avaliado como 6, foram correlacionados a tumores de agressividade intermediária. Já aqueles que apresentaram tumores equivalentes ao GG = 7 ou 8 , foram considerados portadores de tumores de característica biologicamente agressiva, de acordo com Polasciket al.(1999) e Boorjianet al. (2008). Das amostras positivas para o rearranjo TMPRSS2/ERG, encontram-se as duas com o maior Grau de Gleason $(\mathrm{GG}=8)$, sendo que quatro amostras positivas também apresentaram um GG elevado $(\mathrm{GG}=7)$, ou seja, $85,71 \%$ das amostras positivas apresentaram tumores agressivos, sendo que apenas uma delas apresentou tumor cujo comportamento foi avaliado como de agressividade intermediária (Tabela 14). 
Tabela 13 - Identificação dos 20 pacientes em estudo, registro HCFMRP-USP, idade no momento de submissão à prostatectomia radical, grau de Gleason e comprometimento da próstata pelo tumor. Os números atribuídos a cada paciente respeitam à ordem de seu registro no Banco de Tumores Urogenitais e as abreviações que os seguem são as iniciais de seus nomes, a fim de preservar suas identidades. As linhas evidenciadas em cinza correspondem aos pacientes portadores do rearranjo TMPRSS2/ERG.

\begin{tabular}{|c|c|c|c|c|}
\hline Paciente & $\begin{array}{l}\text { Registro } \\
\text { HC }\end{array}$ & $\begin{array}{l}\text { Idade* } \\
\text { (anos) }\end{array}$ & Grau de Gleason & Comprometimento \\
\hline 1-PCS & 0808628I & 73 & $3+5=8$ & Região periférica (LP) e bilateralmente \\
\hline $2-\mathrm{OF}$ & 03322E & 66 & $3+4=7(\mathrm{LD}) / 3+3=6(\mathrm{LE})$ & $45 \%$ (LD) e $25 \%$ (LE) \\
\hline 3-GGC & $053560 \mathrm{E}$ & 67 & $3+4=7$ & $(\mathrm{AE})$ \\
\hline 4-RK & 0814996C & 67 & $3+3=6$ & Extensamente (AD), (TMD) e (TME) \\
\hline 5-AP & 0055870B & 71 & $3+3=6$ & (LP), (LD) e principalmente (LE) \\
\hline 6-VAS & 0681954 & 63 & $3+4=7$ & $\begin{array}{c}\text { Extensamente (AD), (TMD) e (TME) e } \\
\text { focalmente (AD) }\end{array}$ \\
\hline 7-NJO & $0782205 \mathrm{~A}$ & 63 & $3+4=7$ & (LD) e (LE) \\
\hline 8-JF & $0800123 \mathrm{H}$ & 62 & $4+4=8$ & Mais da metade (LE) \\
\hline 9-JHA & 0839705B & 65 & $3+4=7$ & Extensamente (LE) e focalmente (LD) \\
\hline 10-RMSG & 0813923J & 66 & $3+3=6$ & $40 \%(\mathrm{LD})$ e $30 \%(\mathrm{LE})$ \\
\hline 11-JRAC & $0818400 \mathrm{H}$ & 64 & $3+4=7$ & (LE) e (LD) \\
\hline 12-JGM & 0492646I & 66 & $3+4=7$ & 25 a $50 \%$ (LD) e múltiplos focos (NI) \\
\hline 13-LBS & $0639022 \mathrm{H}$ & 72 & $3+4=7$ & Porção (LD), (AE) e base (LE) \\
\hline 14-SM & 0822363J & 70 & $3+4=7$ & $\begin{array}{l}\text { Extensamente (LP), principalmente à } \\
\text { direita e focalmente (LD), } \\
\text { bilateralmente }\end{array}$ \\
\hline 15-ECC & 0691073G & 63 & $3+3=6$ & (LD) e (LE) em seus (TM) e (B) \\
\hline 16-OGR & 0814036B & 60 & $3+4=7$ & $\begin{array}{l}\text { Difusamente (LD) e multifocalmente } \\
\text { (LE) }\end{array}$ \\
\hline 17-ABS & $0818701 \mathrm{H}$ & 68 & $3+3=6$ & $30 \%$ (LE) e metade (LD) \\
\hline 18-JFM & $0493573 I$ & 66 & $3+4=7$ & $\begin{array}{l}\text { Extensamente (LE) e múltiplos focos } \\
\text { (NI) }\end{array}$ \\
\hline 19-SSC & 0698965A & 67 & $3+4=7$ & Porção (TME), (AD) e focalmente (LP) \\
\hline 20-JATS & 0856775B & 70 & $3+4=7$ & Mais da metade (LD) e (B) \\
\hline
\end{tabular}

* Idade no momento da cirurgia; (LD) Lobo direito, (LE) Lobo esquerdo, (AE) Ápice esquerdo, (AD) Ápice direito, (LP) Lobo posterior, (TM) Terço médio, (TMD) Terço médio direito, (TME) Terço médio esquerdo, (NI) Neoplasia intraepitelial e (B) Base.

Tabela 14 - Relação entre as amostras portadores e não portadores do rearranjo TMPRSS2/ERG com o seu respectivo Grau de Gleason.

\begin{tabular}{ccc}
\hline & Amostras TMPRSS2/ERG positivas & Amostras TMPRSS2/ERG negativas \\
\hline GG>6 & $6(85,71 \%)$ & $8(66,66 \% 0$ \\
GG=6 & $1(14,29 \%)$ & $4(33,34 \%)$ \\
Total & 7 & 13 \\
\hline
\end{tabular}

Quanto à classificação TNM, apenas um paciente não pôde ser avaliado, esse dado não constava em seu prontuário. Dos 19 pacientes, 17 apresentaram tumores considerados clinicamente confinados à próstata (T2), sendo 14 destes com o tumor envolvendo dois lobos (T2c) e três considerados tumores incidentais de achado histopatológico em $\leq 5 \%$ do tecido de ressecção (T2a) (Tabela 15). Dois pacientes 
apresentaram tumores com extensão além da cápsula prostática (T3), unilateral ou bilateral (T3a). Estes últimos, ambos continham o rearranjo TMPRSS2/ERG. Os demais pacientes portadores do rearranjo apresentaram tumores em dois lobos da próstata (T2c).

Não houve acometimento dos nódulos regionais em 13 pacientes (N0), e os outros seis não foram avaliados para este critério $(\mathrm{Nx})$. Nenhum dos pacientes apresentou metástase até o momento da prostatectomia radical. Daqueles que tiveram seguimento pós-operatório até o ano de 2011, nenhum apresentou metástase, sendo que houve perda de seguimento para três pacientes.

Tabela 15 - Seguimento clínico e molecular dos pacientes após a prostatectomia radical: recorrência de PSA, presença do rearranjo TMPRSS2/ERG, metástase, invasão de vesícula seminal (VS) e estadiamento. As linhas evidenciadas em cinza correspondem aos pacientes portadores do rearranjo TMPRSS2/ERG.

\begin{tabular}{|c|c|c|c|c|}
\hline Paciente & $\begin{array}{l}\text { Ano da } \\
\text { Cirurgia }\end{array}$ & Recorrência de PSA & $\begin{array}{l}\text { Invasão } \\
\text { (VS) }\end{array}$ & Estadiamento \\
\hline 1 & 2007 & Não, até out/2011 & Não & pT2c pN0 pMx \\
\hline 2 & 2007 & Não, até mar/2011 & Não & pT2c pN0 pMx \\
\hline 3 & 2007 & Não, até out/2011 & Não & pT2a pN0 pMx \\
\hline 4 & 2007 & Não, até dez/2009- (PS) após essa data & Não & $\mathrm{pT} 2 \mathrm{c} \mathrm{pN} 0 \mathrm{pMx}$ \\
\hline 5 & 2007 & Não, até dez/2008- (PS) após essa data & Não & pT2c pN0 pMx \\
\hline 6 & 2008 & Não, até abr/2011 & Não & $\mathrm{pT} 2 \mathrm{c} \mathrm{pN} 0 \mathrm{pMx}$ \\
\hline 7 & 2008 & Sim, em jan/2011 (25 ng/dl) & Não & pT2c pN0 pMx \\
\hline 8 & 2008 & $\begin{array}{c}\text { Sim, em set/2008 (21ng/dl)- feita (RT), } \\
\text { (SR) até ago/2011 }\end{array}$ & Não & pT3a pN0 pMx \\
\hline 9 & 2008 & Não, até nov/2011 & Não & pT2c pNx pMx \\
\hline 10 & 2007 & Não até ago/2011 & Não & pT2c pN0 pMx \\
\hline 11 & 2007 & $\begin{array}{c}\text { Sim, em ago/2008 (21 ng/dl), feita } \\
(\mathrm{RT}), \mathrm{com}(\mathrm{RB}) \text { em set/2009 (20 } \\
\text { ng/dl), (HR) }\end{array}$ & Não & $\mathrm{pT} 2 \mathrm{c} \mathrm{pNx} \mathrm{pMx}$ \\
\hline 12 & 2008 & Não até set/2011 & Não & pT3a pN0 pMx \\
\hline 13 & 2008 & $\begin{array}{l}\text { Sim, em abr/2010 (41 ng/dl) evoluiu } \\
\text { (RB) }(61 \mathrm{ng} / \mathrm{dl}) \text {, feita (RT) }\end{array}$ & Sim & SD \\
\hline 14 & 2007 & $\begin{array}{l}\text { Não, mas investigando CA a partir de } \\
\text { mar/2011 (17ng./dl) }\end{array}$ & Não & pT2c pN0 pMx \\
\hline 15 & 2007 & Não até abr/2008- (PS) após essa data & Não & pT2c pNx pMx \\
\hline 16 & 2007 & Não até ago/2011 & Não & pT2a pNx pMx \\
\hline 17 & 2008 & Não até ago/2009, (PS) após essa data & Não & $\mathrm{pT} 2 \mathrm{c} \mathrm{pNx} \mathrm{pMx}$ \\
\hline 18 & 2007 & Não até dez/2011 & Não & pT2c pNx pMx \\
\hline 19 & 2007 & Não até mar/2011 & Não & pT2a pN0 pMx \\
\hline 20 & 2008 & Não até mai/2011 & Não & pT2c pN0 pMx \\
\hline
\end{tabular}

(VS) Vesícula seminal, (RB) Recidiva bioquímica, (SR) Sem recidiva, (VSD) Vesícula seminal direita, (PRR) Prostatectomia Radical, (HR) Hormônio resistente, (PS) Perda de seguimento, (CA) Curva ascendente, (SD) Sem diagnóstico.

Três pacientes tiveram seu acompanhamento pós-operatório perdido, não havendo explicação do motivo em seus prontuários. Os 17 pacientes restantes foram 
seguidos até o fim do ano de 2011 (as datas de avaliação do nível de PSA encontram-se na Tabela e dizem respeito ao mês e ano da última consulta). Destes, houve recorrência bioquímica (RB) de PSA em quatro pacientes. O paciente 7 apresentou RB três anos após a ressecção e foi conduzido à radioterapia (RT). O paciente 8 , portador do rearranjo TMPRSS2/ERG, teve RB no mesmo ano da ressecção, realizou RT, não apresentando RB até o fim de 2011. O paciente 11 recidivou um ano após a ressecção e a conduta clínica foi a RT, apresentando nova recidiva um ano depois, sendo considerado hormônio resistente (não havia mais dados sobre seu seguimento após essa data). Também foi identificada recidiva para o paciente 13 dois anos após a ressecção, foi tratado com RT, sem recidivas até 2011. 
6. DISCUSSÃO 


\section{DISCUSSÃO}

O diagnóstico molecular do $\mathrm{CaP}$ é complexo, considerando-se as recorrentes mutações em oncogenes e/ou genes supressores tumorais presentes nesta neoplasia. Entre essas alterações genéticas, a mais comum, diz respeito a um rearranjo gênico determinado pela fusão entre os genes TMPRSS2 (andrógeno regulado), e o gene ERG (fator de transcrição) de significativa importância biológica para o CaP (TOMLINS S.A. et al., 2005). Outros rearranjos envolvendo fatores de transcrição no $\mathrm{CaP}$ são evidenciados também, mas o TMPRSS2/ERG é de longe o mais comum (MEHRA R. et al. 2007; HAN B. et al., 2008 e KUMAR-SINHA C. et al., 2008).

Rearranjos cromossômicos que resultam em genes de fusão que expressam proteínas funcionais são comuns em neoplasias não-epiteliais (MITELMAN F., 2000) e em certas malignidades, tais como a leucemia mieloide crônica, na qual a presença do gene de fusão $(B C R-A B L)$ é crítica para o diagnóstico, sendo a proteína de fusão um alvo terapêutico chave. Da mesma maneira, a descoberta pioneira de rearranjos cromossômicos em tumores sólidos, especificamente o TMPRSS2/ERG, representa uma mudança no paradigma de estudo do CaP e de outros tumores sólidos (TOMLINS S.A. et al. 2005).

Como visto na introdução deste estudo, há uma relevante literatura referente à frequência desse rearranjo em portadores de $\mathrm{CaP}$ oriundos de diversas etnias e países (WANG J. et al., 2005 e CERVEIRA N. et al., 2006). Entretanto nenhuma evidência de estudos desse caráter foi observada no Brasil até o momento. Dessa forma, a fim de identificarmos o perfil de incidência dessa fusão em pacientes brasileiros, associando-os aos seus perfis clínicos e genéticos, procedemos com sua investigação.

Em uma primeira análise, identificamos que a frequência desse rearranjo foi de $35 \%$ em um total de 20 pacientes selecionados. Estudos anteriores, encontraram frequências entre 15 a $80 \%$ dos CaPs (WANG J. et al., 2006; YOSHIMOTO M. et al., 2008; CLARK J. et al., 2007; MEHRA R. et al. 2007). O que foi consonante em todos estes trabalhos é que a frequência desse rearranjo foi condicionada a vários fatores, tais como idade, etnia de origem, hábitos de vida, técnica de análise, fase clínica investigada, entre outros. 
Para compreendermos quais desses possíveis fatores estariam relacionados à frequência por nós encontrada, garantimos antes de tudo a qualidade do RNA empregado, checando sua concentração por espectrofotometria e a sua qualidade em gel de agarose a 1,2\%. Quanto à técnica de detecção empregada, a RT-PCR (transcrição reversa seguida de amplificação pela cadeia da polimerase) demonstrou ser mais sensível do que o FISH, ambas já bem estabelecidas para análise da expressão gênica desse rearranjo no tecido prostático. Houve uma prevalência de positividade da fusão na maioria dos estudos que empregaram RT-PCR (52\%) em relação àqueles que utilizaram o FISH (42\%) como técnica (PETTERSON A. et al., 2012). Entretanto, foge do escopo deste trabalho fazer qualquer inferência a respeito de qual o melhor método a se empregar para detecção deste rearranjo, visto a dependência a uma série de outros fatores relevantes para tal. Objetivamos, por meio dessa observação, apenas sustentar que não há literatura disponível que estabeleça relação entre a técnica por nós utilizada e a frequência encontrada.

Um levantamento de estudos publicados posteriormente ao descobrimento dos rearranjos ETS no câncer de próstata, em 2005, foi desenvolvido por Tomlins et al. (2009) e revelou que em 2218 casos de ressecção prostática de CaP provenientes de países da América do Norte, Europa e Ásia foram identificadas frequências de, aproximadamente, $50 \%$ de portadores do rearranjo TMPRSS2/ERG (DAI M.J. et al., 2008; FURUSATO B. et al., 2008; KUMAR-SINHA C. et al., 2008; LU Q. et al., 2008; ROUZIER C. et al., 2008; SARAMAKI O.R. et al., 2008; YOSHIMOTO M. et al., 2008; DARNEL A.D et al., 2009; GOPALAN A. et al., 2009). Frequência próxima a essas também foi verificada em biópsias (isto é, nível elevado de PSA ou exame retal anormal) em um estudo empreendido por Mosquera et al. (2008).

Até o momento já se demonstrou que a taxa de CaPs fusão positivos é maior em caucasianos $(50 \%-52 \%)$ do que em afro-americanos $(31,3 \%)$ ou Japoneses $(15,9 \%)$ (MOSQUERA, J.M. et al., 2009; MAGI-GALLUZZI, C. et al., 2011). Em outro trabalho, meta-analítico, os resultados estatísticos a respeito de vários trabalhos orientados para a identificação desse rearranjo em ressecções prostáticas, desde a sua descoberta, demonstraram que o mesmo foi detectado em torno de $49 \%$ dos casos. Sendo assim, é possível que a nossa baixa amostragem ou mesmo um viés de seleção tenha contribuído para o encontro de uma frequência menor, porém, como visto, há frequências ainda menores descritas na literatura (PERTTERSSON A. et al., 2012) 
Além disso, é necessário enfatizar, também, o viés de origem das nossas amostras. Como já dito, nenhum trabalho referente a esse rearranjo havia estudado-o em uma população brasileira. Sendo assim, dada à alta heterogeneidade étnica no Brasil, é possível que algum componente genético ou uma possível interação ambiental venham a influenciar a orientação da formação desses rearranjos. Apesar de se tratar apenas de uma hipótese, há indícios de correlação entre a prevalência de portadores do rearranjo TMPRSS2/ERG e a sua origem, já que se verificou que ela diferiu entre os diferentes continentes analisados.

Outra consideração a ser feita diz respeito à característica biológica do $\mathrm{CaP}$. Como já visto, a neoplasia da próstata apresenta comportamento heterogêneo, sendo que populações genomicamente distintas coexistem e determinam o fenótipo da doença (TOMULEASA C. et al., 2010). Mais do que 90\% das glândulas prostáticas afetadas no CaP contêm vários tipos tumorais independentes (FALZARANO, S.M. et al., 2011). Como consequência, os achados moleculares podem ser heterogêneos e muitas vezes, permanecem sem serem detectados. Como nossas amostras são provenientes de diferentes porções da ressecção prostática, não se pode afirmar que representem fielmente o contexto genômico das neoplasias de origem. Portanto, é provável que haja pacientes em que o rearranjo não tenha sido detectado na porção da próstata por nós estudada, mas que estes sejam portadores do rearranjo em outros sítios do tumor.

Já em uma segunda análise, levamos em consideração a significativa heterogeneidade na estrutura da extremidade 5' dos transcritos de mRNA do gene de fusão TMPRSS2/ERG (WANG J. et al., 2003; TOMLINS S.A. et al., 2006 e CLARK J. et al., 2007). Vimos que alguns CaP expressam uma única isoforma do mRNA, enquanto outros expressam múltiplas isoformas do gene de fusão, que surgem através de splicing alternativo do transcrito de fusão inicial. Inicialmente, Wang J. et al. (2005) caracterizaram 8 tipos dessa fusão em $\mathrm{CaP}$, que foram confirmadas por outros estudos (CERVEIRA N. et al., 2006 e DEMICHELIS F. et al., 2007), e outras isoformas também foram identificadas.

Nossos resultados mostraram que todos os casos positivos apresentaram as características da isoforma do tipo III. Optamos por esta denominação por se tratar da primeira nomenclatura estabelecida para esse transcrito por WANG et al., 2006, outras foram indicadas, mas ainda não há consenso literário a respeito. Este é o transcrito mais 
comumente encontrado, ele contém o éxon 1 (16-71pb) do TMPRSS2 (importante por conter a região promotora desse gene, andrógeno responsiva) fundido com o éxon 4 (226-762pb) do gene ERG. O rearranjo como um todo apresentou uma extensão de 591pb. A região de fusão entre eles pôde ser caracterizada por 20pb: AGCGCGGCAGGAAGCCTTAT, sendo a região não sublinhada pertencente ao gene $T M P R S S 2$ e a região sublinhada ao gene $E R G$. A tradução desse transcrito é predita acontecer a partir de um códon ATG interno no éxon 4 do $E R G$, podendo resultar em uma proteína ligeiramente truncada (WANG J. et al., 2006).

A despeito dos mais de 20 tipos de transcritos TMPRSS2/ERG já identificados (TOMLINS S.A. et al., 2005; WANG J. et al., 2006; SOLLER M.J. et al., 2006; CLARK J. et al., 2007 e CLARK J. et al., 2008) resultantes, na maioria das vezes, de splicing alternativo, há uma clara prevalência da isoforma do tipo III entre os rearranjos TMPRSS2/ERG na literatura (WANG J. et al., 2006; TU J.J., et al. 2007; DAI M.J. et $a l ., 2008)$. Observou-se que há uma andrógeno-dirigência no promotor do TMPRSS2 (LIN B. et al., 1999) superexpressando constitutivamente essa porção do gene $E R G$ no epitélio prostático, já que a atividade dos receptores de andrógeno (AR) é ubíqua nesse órgão. Esses altos níveis de expressão foram associados a características agressivas do CaP (TOMLINS S.A. et al., 2005 e WANG J. et al. 2006).

Sabendo-se que a fusão TMPRSS2/ERG desempenha um papel crítico na carcinogênese da próstata (CERVEIRA N. et al., 2006 e PERNER S. et al., 2007) e que os fatores de transcrição ETS estão associados a genes mitógenos (SETH A. et al., 2005), presume-se que essa isoforma esteja envolvida na progressão do tumor. A maioria dos estudos mostraram associação entre a presença da fusão TMPRSS2/ERG e o CaP agressivo (WANG J. et al., 2006; SOLLER M.J. et al., 2006; DEMICHELIS F. et al. 2007; RAJPUT A.B. et al., 2007; LAPOINT J. et al., 2007a; LAPOINT J. et al., 2007b; ATTARD G. et al., 2008). Os casos que expressaram a isoforma do tipo III juntamente com a isoforma do tipo VI (que traduz proteína $E R G$ truncada), se mostraram mais agressivas do que aquelas que expressaram a isoforma do tipo III isolada. Além disso, alguns casos que expressavam somente a isoforma do tipo III apresentaram níveis elevados de expressão do gene de fusão, também associada à doença agressiva (WANG J. et al., 2006). 
Entretanto, Tomlins et al. (2008) em um estudo funcional dos transcritos TMPRSS2/ERG observaram que o knockdown da isoforma do tipo III em camundongos SCID influenciou menos na progressão da neoplasia prostática do que o knockdown da isoforma do tipo VI, onde a proliferação das células foi drasticamente reduzida. Corroborando com tal evidência Wang J. et al. (2009) demonstraram que a isoforma do tipo III não promove a proliferação, mas melhora a invasão e a mobilidade das células tumorais, embora de maneira menos eficaz que o tipo VI, o que indica uma atividade pleiotrópica de cada isoforma específica (WANG J. et al., 2009).

Em uma análise final, investigamos individualmente cada sujeito da pesquisa, considerando idade, características histopatológicas do tumor e de progressão da doença, a fim de identificarmos uma possível relação entre essas variáveis e o rearranjo TMPRSS2/ERG. Uma grande variabilidade entre eles foi identificada, presumível, dada a heterogeneidade do $\mathrm{CaP}$, o que torna a análise mais complexa. Houve perda de seguimento de três pacientes $(15 \%)$. Os demais pacientes se encontravam vivos até o final de 2011, período que escolhemos para o estudo. A localização específica desses participantes não foi objeto de pesquisa, uma vez que sua determinação seria irrelevante considerando que não estaria, necessariamente, relacionada à sua descendência étnica, dada a alta miscigenação brasileira com outros povos provenientes de outras nações, resultando em alta variabilidade genética.

A idade média entre eles foi de 66,28 (63 - 72 anos) e mediana de 65 anos no momento da cirurgia de remoção da próstata, ou seja, foram acometidos em uma faixa etária mais avançada. Apesar de estudos mostrarem que a associação entre o risco de CaP e a idade é muito forte (JEMAL A. et al., 2010) não se pode dizer que ela seja um preditor de risco independente para o mesmo (SCHRÖDER F.H. et al., 2009). Também não há evidências de associação entre a idade dos pacientes e a presença do rearranjo TMPRSS2/ERG.

Entre os pacientes portadores da fusão, apenas um deles apresentou recidiva bioquímica de PSA $(14,27 \%)$ e outro vêm apresentando curva ascendente de PSA no último ano, 2011. Entretanto, em pesquisa que avaliava correlação entre a presença do rearranjo TMPRSS2/ERG detectado na urina com dados clínicos e anatomopatológicos verificou-se que não houve associação com o PSA sérico, o que é coerente com os nossos achados (TOMLINS, S.A. et al., 2011). Neste mesmo trabalho e em uma outra 
pesquisa, verificou-se associação com o peso da próstata e sua dimensão e uma maior associação com pacientes que apresentaram GG superior a seis, comportamento também identificado em nosso estudo, onde seis dos sete pacientes positivos para a fusão apresentavam fenótipo correspondente ao $\mathrm{CaP}$ mais agressivo (MINNER, S. et al., 2011). Evidenciamos porcentagem inferior de pacientes com este fenótipo agressivo no grupo de pacientes não portadores da fusão $(66,66 \%)$.

Há análises moleculares que têm sugerido várias aberrações moleculares que diferem entre CaPs positivos e negativos para o rearranjo TMPRSS2/ERG, tais como deleções do gene PTEN, que estavam presentes em uma porcentagem mais elevada em cânceres fusão-positivos comparados com fusão-negativos (CARVER B.S. et al., 2009; HAN B. et al., 2009). Apesar de tais achados sugerirem diferenças biológicas significativas, o impacto clínico das fusões de genes da família ETS ainda é incerto no CaP. Enquanto alguns estudos têm sugerido um pior prognóstico quando a fusão está presente (PERNER S. et al.2006; WANG J. et al. 2006; DEMICHELIS F. et al., 2007; NAM R.K. et al., 2007), outros encontraram uma associação ou prognóstico favorável (SARAMAKI, O.R. et al., 2008; WINNES, M. et al., 2007), e há até mesmo aqueles que não encontraram nenhuma associação (FITZGERALD L.M. et al., 2008; GOPALAN, A. et al., 2009). Esses resultados conflitantes podem ser parcialmente devido a diferenças no tamanho da coorte e sua composição, na terapia, e no prognóstico entre esses diferentes estudos (TOMLINS S.A. et al., 2009).

A despeito de todas esses conflitos, pode-se dizer que já há uma correlação já bem estudada e aceita, trata-se da relação entre portadores da fusão e maior expressão de receptores AR, que demonstrou ser benéfica para o tratamento do CaP. Attard et al. (2008) mostraram que homens andrógeno-resistentes apresentaram melhor resposta quando tratados com acetato de abiraterona se seus tumores eram TMPRSS2/ERG positivos em comparação com tumores negativos. Corroborando para tal, outro estudo recente mostrou que os pacientes com tumores fusão- positivos demonstraram um efeito de tratamento mais significativo, em resposta à privação de andrógeno (KARNNES R.J. et al., 2010). Isto pode ser devido ao fator de transcrição ERG em tumores positivos serem particularmente dependentes de um AR funcional porque o $E R G$ só pode ser super-expresso na presença de AR (MINNER, S. et al., 2011). 
Em suma, podemos dizer que há uma forte orientação para a utilização desse rearranjo tanto cientificamente como também na prática clínica, visto os benefícios para o manejo clínico desta doença no país e no mundo. Ressaltamos a necessidade de continuidade deste trabalho para determinação de novas frequências com amostragens maiores e mais representativas das diferentes regiões do país, dado o potencial já demonstrado desse rearranjo no CaP e para que novas abordagens dessa fusão sejam descobertas. 
7. CONCLUSÕES 


\section{Conclusões}

Os resultados obtidos neste trabalho permitem concluir que:

- Foi encontrada uma frequência de $35 \%$ de portadores da fusão TMPRSS2/ERG em uma população de 20 indivíduos de nacionalidade brasileira diagnosticados com câncer de próstata; dada baixa frequência, sugere-se uma possível relação com origem brasileira das amostras;

- Entre os portadores da fusão TMPRSS2/ERG identificamos que todos pertenciam à classificação de isoforma do tipo III, coerente com a literatura que demonstra que essa isoforma é o tipo mais comumente encontrado em ressecções prostáticas fusão positivas;

- Houve correlação dessa isoforma com a idade e dados histopatológicos dos pacientes (GG e TNM), demonstrando um comportamento mais agressivo do tumor entre os portadores da mesma. Nenhuma correlação pode ser estabelecida quanto à progressão da doença (RB de PSA e invasão de VS). 


\section{REFERÊNCIAS}

Ministério da Saúde. Secretaria Nacional de Assistência à Saúde. Instituto Nacional de Câncer. Coordenação de Prevenção e Vigilância - Conprev. Câncer da próstata: consenso - Rio de Janeiro: INCA, 2002.

ABATE-SHEN, C. E SHEN, M.M. Molecular genetics of prostate cancer. Genes Dev. v.14, p. 2410-34, 2000.

ADACHIA, J. et al. The human urinary proteome contains more than 1500 proteins, including a large proportion of membrane proteins. Genome Biol. v.7, p.80, 2006.

ALEMOZAFFAR, M. et al. Prediction of erectile function following treatment for prostate cancer. JAMA v.306, p.1205-1214, 2011.

ALTMAN, D.G. Systematic reviews of evaluations of prognostic variables. B.M.J. v.323, p.224-8, 2001.

AMUNDADOTTIR, L.T. et al. A common variant associated with prostate cancer in European and African populations. Nat Genet.; p.38:652-658, 2006.

ARORA, R. et al. Heterogeneity of Gleason grade in multifocal adenocarcinoma of the prostate. Cancer, v.100, p.2362-66, 2004.

ASTORG, P. Dietary N-6 and N-3 polyunsaturated fatty acids and prostate cancer risk: a review of epidemiological and experimental evidence. Cancer Causes Control, v.15, p.367-86, 2004.

ATTARD, G. et al. Characterization of ERG, AR and PTEN gene status in circulating tumor cells from patients with castration-resistant prostate cancer. Cancer Res., v.69, p.2912-2918, 2009.

AUBIN, S.M. et al. Improved prediction of prostate biopsy outcome using PCA3, TMPRSS2:ERG gene fusion and serum PSA. J. Urol. v.179 (Suppl.), p.725, 2008.

AUPRICH, M. et al. External validation of urinary PCA3-basad nomograms to individualy predict prostate biopsy outcome. Eur. Urol., v.58, p.727-732, 2010.

ACC (AVISORY COMMITTEE ON CANCER). Recommendations on cancer screening in European Union prevention. Eur. J. Cancer, v.36, p.1473-8, 2000.

BADEN, J. et al. Multicenter evaluation of an investigational prostate cancer methylation assay. J. Urol. v.182, p.1186-93, 2009.

BERTILSSON, H. et al. RNA quality in fresh frozen prostate tissue from patients operated with radical prostatectomy. Scand J Clin Lab Invest.;v.70, p.45-53, 2010.

BEST, S. et al. Integrity of prostatic tissue for molecular analysis after robotic-assisted laparoscopic and open prostatectomy. Urology, v.70, p.328-332, 2007.

BILL-AXELSON, A. et al. Radical prostatectomy versus watchful waiting in early prostate cancer. $N$. Engl. J. Med., v.364, p.1708-17, 2011.

BONO, J.S. et al. Abiterone and incresead survival in metastatic prostate cancer. N. Engl. J. Med., v.364, p.1995-2005, 2011.

BONO, J.S. et al. Prednisone plus cabazitexxel or mitoxantrone for metastatic castration-resistant prostate cancer progressing after docetaxel treatment randomised open-label trial. Lancet, v. 376, p.1147-1154, 2010 .

BOORJIAN, S.A. et. al. Mayo Clinic validation for the D'Amico risk group classification for predicting survival following radical prostatectomy. J. Uro., v.179, p.1354, 2008. 
BOSTWICK, D.G. et al. Human prostate cancer risk factors. Cancer, v.101 (suppl.), p.2371-2490, 2004. BRASIL. Conselho Nacional de Saúde. Lei $n^{\circ} 196$, de 10 de outubro de 1996. Dispõe sobre a pesquisa com seres humanos. Diretrizes e normas regulamentadoras da pesquisa envolvendo seres humanos. Brasília, 1996.

BRASIL. Ministério da Saúde. Instituto Nacional do Câncer - INCA. Incidência de Câncer no Brasil: Estimativa de incidência da neoplasia da próstata para o ano de 2012. Rio de Janeiro, 2012. Disponível em: http://wwwl.inca.gov.br/estimativa/2012/index.asp. Acessado em 20 de julho de 2012.

BRASSEL, S.A. et al. Prostate cancer in men 70 years old or older, indolent or aggressive: clinicopathological analysis and outcomes. J. Urol., v.185, p.132-7, 2011.

BRATT, O. Hereditary prostate cancer: clinical aspects. J. Urol., v.168, p.906-13, 2002.

BROOKS, D.D. et al. Prostate cancer screening 2010: update recommendations from the American Cancer Society. J. Natl. Med. Assoc., v.102, p.423-429, 2010.

BRUNER, D.W. et. al. Relative risk of prostate cancer for men with affected relatives: systematic review and meta-analysis. Int. J. Cancer, v.107, p.797-803, 2003.

CAI, C. et al. ETV1 is a novel androgen receptor-regulated gene that mediates prostate cancer cell invasion. Mol. Endocrinol., v.21, p.1835-1846, 2007.

cancer. Genes Chromosomes Cancer.; v.45, p.717-719, 2006.

CARTER, B.S. et al. Hereditary prostate cancer: epidemiologic and clinical features. J. Urol., v,150, p.797-802, 1993.

CARVER, B.S. et al. Aberrant ERG expression cooperates with loss of PTEN to promote cancer progression in the prostate, Nat. Genet., v.41, p.619-624, 2009.

CARVER, B.S. et al. ETS rearrangement and prostate cancer initiation. Nature 457: E1-3, 2009.

CATALONA, W.J. et al. Measurement of prostate-specific antigen in serum as a screening test for prostate cancer. N. Engl. J. Med., v.324, p.1156, 1991.

CERVEIRA, N. et al. TMPRSS2-ERG gene fusion causing ERG overexpression precedes chromosome copy number changes in prostate carcinomas and paired HGPIN lesions. Neoplasia, v.8, p.826-32, 2006.

CHANG, B.L. et al. Two-locus genome-wide linkage scan for prostate cancer susceptibility genes with an interaction effect. Hum Genet., v.118, p.716-724, 2006.

CLARK, J. et al. Complex patterns of ETS gene alteration arise during cancer development in the human prostate. Oncogene; v.27, p.1993-2003, 2008.

CLARK, J. et al. Diversity of TMPRSS2-ERG fusion transcripts in the human prostate. Oncogene, v.26, p.2667-2673, 2007.

CLARKE, M. Cancer Stem Cells - Perspectives on Current Status and Future Directions: AACR workshop on Cancer Stem Cells. Cancer Res., v.66, p.9339-44, 2006.

COLLIS, J. E HUSSEY, R. Pesquisa em administração. 2ª ed. Bookman, São Paulo, 2005.

COLOMBO, P. et al. Molecular disorders in transitional vs. peripheral zone prostate adenocarcinoma. Int. J. CanceR, v.94, p.383-89, 2001.

COLOTTA, F. et al. Cancer-related inflammation, the seventh hallmark of cancer: links to genetic instability. Carcinogenesis, v.30 (7), p.1073-1081, 2009.

COOPERATIVE GROUP FOR DIAGNOSIS OF PROSTATE CANCER. A multicenter study on the detection of prostate cancer by digital retal examination and prostate-specific antigen in men with or without urinary symptoms. Eur. Urol., v.32, p.122-9, 1997. 
COOPERBERG, M.R. et al. Time trends in clinical risK stratification for prostate cancer: implications for outcomes. J. Urol., v.170, p.S21-5, 2003.

CORRÊA, L.A. et al. Câncer de Próstata: fatores prognósticos- Projeto Diretrizes da Associação Médica Brasileira e Conselheiro Federal de Medicina elaborado por colaboradores da Sociedade Brasileira de Urologia. Disponível em: http://www.projetodiretrizes.org.br/novas diretrizes.php. Acessado em julho de 2012.

CRAWFORD, E.D. Understanding the epidemiology, natural history, and key pathways involved in prostate cancer.Urology, v.73 (5 Suppl.), p.S4-10, 2009.

CUSSENOT, O.; VALERI, A. Heterogeneity in genetic susceptibility to prostate cancer. Eur J Intern Med., v.12, p.11-16, 2001.

DAI, M.J. et al. Frequency and transcript variant analysis of gene fusions between TMPRSS2 and ETS transcription factor genes in prostate cancer. Zhonghua Yi Xue Za Zhi, v.88, p.669-673, 2008.

DARNEL, A.D. et al. TMPRSS2/ERG fusion is frequently observed in Gleason pattern 3 prostate cancer in a Canadian cohort. Cancer Biol. Ther., v.8, p.125-130, 2009.

DAS, B. et al. Hypoxia enhances tumor stemness by increasing the invase and tumorigenic side population fraction. Stem Cells, v.26, p.1818-30, 2008.

DE ANGELIS, G. et al. Twenty years of PSA: From prostate antigen to tumor marker. Rev. Urol., v.9, p.113-23, 2007.

DE MARZO, A.M. et al. Pathological and molecular aspects of prostate cancer. Lancet, v.361, p.955-64, 2003.

DEMICHELIS, F. et al. TMPRSS2/ERG gene fusion associated with lethal prostate cancer in a watchful waiting cohort Oncogene, v.26, p.4596-4599, 2007.

DEVENS, B.H. et al. Polyamine depletion therapy in prostate cancer. Prostate Cancer Prostatic Dis., v.3(4), p.275-279, 2000.

DROZ, J.P., Balducci L., Bolla M. et al. Management of prostate cancer in older men: recommendations of a working group of the Iternational Society of Geriatric Oncology. BJU Int. 106: 462-9, 2010.

EGEBLAD, M.; WERB, Z. New functions for the matrix metalloproteinases in cancer progression.Nat. Rev. Cancer 2: 161-74, 2002.

ELKAHWAJ, J.E. et al. Chronic bacterial infection and inflammation incite reactive hyperplasia in a mouse model of chronic prostatitis. Prostate, v.67(1), p.14-21, 2006.

ENGLISH, H.F.; SANTEN, R.J.; ISAACS, J.T. Response of glandular versus basal rat ventral prostatic epithelial cells to androgen withdrawal and replacement. Prostate, v.11, p.229-42, 1987.

EPSTEIN, J.I. et al. The 2005 International Society of Urological Pathology (ISUP) Consensus Conference on Gleason Grading of Prostatic Carcinoma. AM. J. Surg. Pathol., v.29, p.1228-42, 2005.

FALZARANO, S.M. et al. Single focus prostate cancer: pathological features and ERG fusion status. $J$. Urol., v.185, p.4489-494, 2011.

FELDMAN, B.J.; FELDMAN, D. The development of androgen-independent prostate cancer. Nat. Rev. Cancer, v.1, p.34-45, 2001.

FEUER, E.J.; MERRIL, R.M.; HARLEY, B.F. Cancer surveillance series: interpreting trends in prostate cancer - part II: Cause of death misclassification and the recent rise and fall in prostate cancer mortality. J. Natl. Center Inst. 91: 1025, 1999. 
FITZGERALD, L.M. et al. Association of TMPRSS2-ERG gene fusion with clinical characteristics and outcomes results from population basead study of prostate cancer. BMC Cancer, v.8, p.230, 2008.

FLESHNER, N.E. Vitamin E and prostate cancer. Urol. Clin. North Am. 29:107-13, 2009.

FREEDMAN, M.L. et al. Admixture mapping identifies 8q24 as a prostate cancer risk locus in African American men. Proc. Natl. Acad. Sci. USA, v. 103, p.14068-14073, 2006.

FURUSATO, B. et al. ERG oncoprotein expression in prostate cancer: clonal progression of ERGpositive tumor cells and potencial for ErG-basead stratification. Prostate Cancer Prostatic Dis., v.13, p.228-237, 2010.

FURUSATO, urusato B. et al. Mapping of TMPRSS2/ERG fusions in the context of multi-focal prostate cancer. Mod. Pathol., v.21, p.67-75, 2008.

GIOVANNUCCI, E. Tomato Products, Lycopene, and Prostate Cancer. A review of the epidemiological literature. J. Nutr., v.135, p.2030S-1S, 2005.

GOO, Y.A.; GOODLETT, D.R. Advances in proteomic prostate cancer biomarker discovery. J. Prot., v.73 (10), p.1839-50, 2010.

GOPALAN, A. et al. TMPRSS2/ERG gene fusion is not associated with outcome in patients treated by prostatectomy. Cancer Res., v.69, p.1400-1406, 2009.

GREENE, F.L. et al. A.J.C.C. Cancer Staging Manual. 6 ${ }^{\text {th }}$ ed. Chicago: Springer; p.131-44, 2002.

GREENE, K.L. et al. Prostate specific antigen best practice statement: 2009 update. J. Urol., v.189, p.s.2$11,2013$.

GRONBERG, H. Prostate cancer epidemiology. Lancet, v.361, p.859-64, 2003.

GROSKOPF, J. et al. APTIMA PCA3 molecular urine test: development of a method to aid in the diagnosis of prostate cancer. Clin. Chem., v.52, p.1089-95, 2006.

GUNDERSON, K.; WANG, C.Y.; WANG, R. Global prostate cancer incidence and the migration, settlement, and admixture history of the Nothern Europeans. Cancer Epidemiol., v.35 (4), p.320-327, 2011.

GUNDERSON, K.; WANG, C.Y.; WANG, R. Global prostate cancer incidence and the migration, settlement, and admixture history of the Nothern Europeans. Cancer Epidemiol., v.35 (4), p.320-327, 2011.

GUO, C.C. et al. Prostate cancer of transition zone origin lacks TMPRSS2-ERG gene fusion. Mod.Pathol., v.22, p.866-71, 2009.

HAMDY, F.C. Prognostic and predictive factors in prostate cancer.Cancer Treat.Rev., v.27, p.143-51, 2001.

HAN, B. et al. Fluorescence in situ hybridization study shows association of PTEN deletion with ERG rearrangement during prostate cancer progression. Mod. Pathol., v.22, p.1083-1093, 2009. .

HAN, B., et al. A fluorescence in situ hybridization screen for E26 transformation-specific aberrations: identification of DDX5-ETV4 fusion protein in prostate cancer. Cancer Res., v.68, p.7629-37, 2008.

HAQQ, C. et al. Ethnic and racial differences in prostate stromal estrogen receptor. Prostate, v.65, p.101109, 2005.

HARDEN, S.V. et al. Quantitative GSTP1 methylation and the detection of prostate a adenocarcinoma in sextant biopsies. J. Natl. Cancer Inst., v.95, p.1634-7, 2003.

HE, J. et al. Profile of ETS gene expression in human breast carcinoma. Cancer Biol. Ther., v.6, p.76-78, 2007. 
HEIJNSDIJK, E.A. et al. Overdetection, overtreatment and cost in prostate-specific antigen screening for prostate cancer. Br. J. Cancer, v.101, p.1833-8, 2009.

HESSELS, D. et al. Detection of TMPRSS2-ERG fusion transcripts and prostate cancer antigen 3 in urinay sediments may improve diagnosis of prostate cancer. Clin. Cancer Res., v.13, p.5103-8, 2007.

HILL, R.P.; MARIE-EGYPTIENNE, D.T.; HEDLEY, D.W. Cancer stem cells, hypoxia and metastasis. Semin. Radiat. Oncol., v.19(2), p.106-11, 2009.

HUNTCHINSON, L.M. et al. development of a sensitive and specific enzyme-linked immunosorben assay for thymosin beta15, a urinary biomarker of a human prostate cancer. Clin.Biochem., v.38:, p.55871, 2005.

HUNTLY, B.J.; GILLILAND, D.G. Leukaemia stem cells and the evolution of cancer-stem-cell research. Nat. Rev. Cancer., v.5, p.311-21, 2005.

IMAIDA, K. et al. Clinicopathological analysis on cancers of autopsy cases in a geriatric hospital. Pathol Int., v.47 (5), p.293-300, 1997.

Imperato-McGinley, J. e Zhu, Y.S. Androgens and male physiology the syndrome of $5 \alpha$-reductase- 2 deficiency.Mol. Cell Endrocrinol. 198: 51-59, 2002.

JEMAL, A. et al. Cancer Statistics, 2008. C.A. Cancer J. Clin., v.58, p.71-96, 2008.

JEMAL, A. et al. Cancer statistics, 2010. CA Cancer J Clin., v.60, p. 277 -300, 2010.

JONES, R.A.; WENZEL, J. Prostate cancer among African-American males: understanding the current issues. J. Natl. Black Nurses Assoc., v.16, p.55-62, 2005.

JOSHUA, A.M. et al. Prostatic preneoplasia and beyond. Biochim. Biophys Acta, v.1785, p.156-81, 2008.

KANTOFF, P.W. et al. Sipuleucel-T immunotherapy for castration-resistant prostate cancer. N. Engl. J. Med., v.363, p.411-422, 2010.

KARNES, R.J. et al. The ability of biomarkers to predict systemic progression in men with high risk prostate cancer treated surgically is dependent on ERG status. Cancer Res., v.70, p.8994-9002, 2010.

KOBAYASHI, N. et al. Inhibitory effect of dietary fish oil (omega-3 fatty acids) on human prostate cancer progression in severe-combined immunodeficient mice. J. Urol., v.173 (Suppl. 4), Abstract, p.249, 68, 2005.

KOCH, M.O. et al. Characterization and predictors of prostate specific antigen progression rates after radical retropubic prostatectomy. J. Urol., v.164, p.749-53, 2000.

KOPEC, J.A. et al. Screening with proatate specific antigen and metastic prostate cancer risk: a population basead case-control study. J. Urol., v.174, p.495-9, 2005.

KRAL, M. et al. Genetic determinants of prostate cancer.Biomed.Pap. Med. Fac. Univ. Palacky Olomouc Czech Repub., v.155, p.2-9, 2011.

KUMAR-SINHA, C.; TOMLINS, S.A.; CHINNAIYAN, A.M. Recurrent gene fusions in prostate Cancer.Nat. Rev., v.8, p.497-511, 2008.

LANGEBERG, WJ; ISAACS, WB; STANFORD, JL. Genetic etiology of hereditary prostate cancer. Front Biosci.; v.12, p.4101-4110, 2007.

LAWSON, D.A.; WITTE, O.N. Stem cells in prostate cancer initiation and progression. J. Clin. Invest., v.117, p. 2044-50, 2007.

LAXMAN, B. et al. A first-generation multiplex biomarker analysis of urine for the early detection of prostate cancer. Cancer Res., v.68, p.645-9, 2008. 
LIN, B. et al. Prostate-localized and androgen-regulated expression of the membrane-bound serine protease TMPRSS2. Cancer Res., v.59, p.4180-4184, 1999.

LIU, A.Y. et al. Cell-cell interaction in prostate gene regulation and cytodifferentiation. Proc. Natl. Acad. Sci. USA, v.94, p.10705-10, 1997.

LU, Q. et al. A sensitive array-based assay for identifying multiple TMPRSS2/ERG fusion gene variants. Nucleic Acids Res., v.36, p.130, 2008.

LU, Q. et al. Identification of extracellar delta catenin accumulation for prostate cancer detection. Prostate, v.69, p.411-8, 2009.

MAGI-GALLUZZI, C. et al. TMPRSS2-ERG gene fusion prevalence and class are significantly different in prostate cancer of Caucasian, African-American and Japanese patients. Prostate, v.71, p.489-497, 2011.

MAITLAND, N.J. et al. Prostate cancer stem cells: do they have a basal or luminal phenotype?. Horm Cancer, v.2, p.47-61, 2011.

MAN, Y.G.; GARDNER, W.A. Bad seeds produce bad crops: a single stage-process of prostate tumor invasion. Int. J. Biol. Sci., v.4, p.246-58, 2008.

MARTINS, G.A. Manual para elaboração de monografias e dissertações- $2^{\mathrm{a}}$ ed. Atlas São Paulo, p.116, 1994.

MCNEAL, J.E. et al. Zonal distribuition of prostatic adenocarcinoma.Correlation with histologic patttern and direction of spread. Am. J. Surg. Pathol., v.12, p.897-906, 1998.

MCNEAL, J.E. The zonal anatomy of the prostate .Prostate, v.2, p.35-49, 1981.

MEHRA, R. et al. Comprehensive assessment of TMPRSS2 and ETS family gene aberrations in clinically localized prostate cancer. Mod. Pathol., v.20, p.538-44, 2007.

MERRIL, R.M.; STEPHENSON, R.A. Trends in mortality rates in patients with prostate cancer during the era of prostate specific antigen screening. J. Urol., v.162 (2), p.503-10, 2000.

MILLER, E.C. et al. Tomato products, lycopene, and prostate cancer risk. Urol. Clin. North Am., v.29,: p.83-93, 2002.iopsy

MILLER, G.J.; TORKKO, K.C. Natural history of prostate cancer - epidemiologic considerations. Epidemiol. Rev., v.23, p.14-18, 2001.

MINNER, S. et al. ERG status is unrelated to PSA recurrence in radically operated prostate cancer in the absence of antihormonal therapy. Res. Clin. Cancer, v.17, p.5878-5788, 2011.

MITELAMAN, F. Recurrent chromosome aberrations in cancer. Mutat Res., v.462, p.247-53, 2000.

MOORE, K.L.; DALLEY, A.F. Clinically oriented anatomy. Lippincott, Williams \& Williams, $6^{\text {th }} \mathrm{ed}$, p.373-375, 2011.

MOSQUERA, J.M. et al. Prevalence of TMPRSS2-ERG fusion prostate cancer among men undergoing prostate biopsy in the United States. Clin. Cancer Res., v.15, p. 4706-11, 2009.

NAM R.K. et al. Expression of the TMPRSS2/ERG fusion gene predicts cancer recurrence after surgery for localised prostate cancer. Br. J. Cancer, v.97, p.1690-1695, 2007.

NETTER, F.H. Atlas de Anatomia humana. Artmed 2aed., 2000.

NOMURA, A. Body size and prostate cancer.Epidemiol.Rev., v.23, p.126-31, 2001.

OWCZAREK, C.M. et al. Detailed mapping of the ERG-ETS2 interval of human chromosome 21 and comparison with the region of conserved synteny on mouse chromosome 16. Gene, v.324, p.65-77, 2004. 
PALAPATU, G.S. et al. Selective expression of CD44, a putative prostate cancer stem cell marker, in neuroendocrine tumor cells of human prostate cancer. Prostate, v.69, p.787-98, 2009.

PARKIN, D.M. et al. Global cancer statistics, 2002. CA Cancer J Clin., v.55, p.74-108, 2005.

PARTIN, A.W. et al. Combination of prostate-specific antigen, clinical stage, and Gleason score to predict pathological stage of localized prostate cancer. A multi-institutional update. JAMA, v.277, p.1445-51, 1997.

PARTIN, A.W. et al. Prostate specific antigen in the staging of localized prostate cancer: influence of tumor differentiation, tumor volume and benign hyperplasia. J. Urol., v.143, p.747-52, 1990.

PAYNE, S.R. et al. DNA methylation biomarkers of prostate cancer: confirmation of candidates and evidence urine is the most sensitive body fluid for non-invasive detection. Prostate, v.69, p.1257-69, 2009.

PERNER, S. et al. TMPRSS2/ERG fusion associated deletions provide insight into heterogeneity of prostate cancer. Cancer Res., v.66, p.8337-8341, 2006.

PERNER, S. et al. TMPRSS2-ERG fusion prostate cancer: an early molecular event associated with invasion. Am J Surg Pathol., v.31, p.882-8, 2007.

PETTERSON, A. et al. The TMPRSS2/ERG rearrangement, ERG expression, and prostate cancer outcomes: a cohort study and meta-analysis. Cancer Epidemiol. Biomarkers Prev, 2012. publicado primeiramente online. Disponível em: http://cebp.aacrjournals.org.

PETTUS, J.A. et al. Risk stratification for positive lymph nodes in prostate cancer. J. Endourol, v.22, p.1021-1025, 2008.

PLATZ, E.A.; GIOVANNUCC, E. The epidemiology of sex steroid hormones and their signaling and metabolic pathways in the etiology of prostate cancer.J. Steroid Biochem. Mol. Biol., v.92, p.237-253, 2004.

PLOUSSARD, G. et al. Prostate cancer antigen 3 score accurately predicts tumour volume and might help in selecting prostate cancer patients for active surveillance. Eur. Urol., v.59, p.422-29, 2011.

PLOUSSARD, G.; DE LA TAILLE, A. Urine biomarkers in prostate cancer. Nat. Rev. Urol., v.7, p.101-9, 2010 .

POLASCIK, T.J.; OESTERLING, J.E.; PARTIN, A.W. Prostate specific antigen: a decade of discovery what we have learned and where we are going. J. Urol., v.162, p. 293-306, 1999.

PONTI, D. et al. Isolation and in vitro propagation of tumorigenic breast cancer cells with stem/progenitor cell properties. Cancer Res., v.65, p.5506-11, 2005.

POTTER, S.R. et al. Age, prostate-specific antigen, and digital rectal examination as determinants of the probability of having prostate cancer. Urology, v.57, p.1100-4, 2001.

QUINN, M.; BABB, P. Patterns and trends in prostate câncer incidence, survival, prevalence and mortality - part I: International comparisons. BJU Int., v.90, p.162-73, 2002.

REYA, T. et al. Stem cells, cancer, and cancer stem cells. Nature, v.414, p.105-11, 2001.

RICE, K.R. et al. Evaluation of the ETS-related gene mRNA in urine for the detection of prostate cancer. Clin. Cancer Res., v.16, p.1572-6, 2010.

RIES, L. et al. SEER Cancer Statistics Review 1975-2005. National Cancer Institute. Disponível em: http://seer.cancer.gov/csr/ 19752005.

RIETBERGEN, J.B. et al. Evaluation of prostate-specific antigen, digital rectal examination and transrectal ultrasonography in population- based screening for prostate cancer: improving the efficiency of early detection. Br. J. Urol., v.79 (Suppl. 2), p.57-63, 1997. 
ROOBOL, M.J.; HAESE, A.; BIARTELLI A. Tumour markers in prostate câncer III: biomarkers in urine. Acta Oncol., v.50 (Suppl) 1, p.85-9, 2011.

ROUQUAYAROL, M.Z.; ALMEIDA-FILHO, N. Introdução à epidemiologia- 4ª ed, 2006.

ROUZIER, C. et al. Detection of the TMPRSS2-ETS fusion gene in prostate cancinomas: retrospective analysis of 55 formalin-fixed and paraffin-embedded samples with clinical data. Cancer Genet. Cytogenet, v.183, p.21-27, 2008.

ROY, R. et al. Tumor-specific urinary matrix metalloproteinase fingerprinting: identification of high molecular weight urinary matrix metalloprotreinase species. Clin. Cancer Res., v.14, p.6610-7, 2008.

RUBIN, M.A. et al. Should a Gleason score be assigned to a minute focus of carcinoma on prostate biopsy?. Am. J. Surg. Pathol., v.24, p.1634-40, 2000.

RUBIAN, M.A.; MAHER, C.A. E CHINNAIYAN A.M. Common gene rearrangements in prostate cancer. J. Clin. Oncol., v.29, p.2659-3668, 2011.

RUIJTER, E.T. et al. Histological grade heterogeneity in multifocal prostate cancer. Biological and clinical implications.J. Pathol., v.180, p.295-99, 1996.

RUSSO, A.L. et al. Urine analysis and protein networking identify met as marker of metastatic prostate cancer. Clin. Cancer Res., v.15, p.4292-8, 2009.

SANDA, M.G. et al. Quality of life and satisfaction with outcome among prostate-cancer survivors. N. Engl. J. Med., v.358, p.1250-1261, 2008.

SARAMAKI, O.R. et al. TMPRSS2:ERG fusion identifies a subgroup of prostate cancers with a favorable prognosis. Clin. Cancer Res., v.14, p.3395-3400, 2008.

SCHAID, D.J. et al. Evidence for autosomal dominant inheritance of prostate cancer. Am. J. Hum. Genet., v.62, p.1425-38, 1998.

SCHÖDER, F.H. et al. Defining increased future risk for prostate cancer: evidence from a population based screening cohort. J Urol, v.181, p.69-74, 2009.

SCHÖDER, F.H. et al. Screening and prostate cancer mortality in a randomized European study. N. engl. J. Med., v.360, p.1320-8, 2009.

SCHOSTAK, M. et al. Annexin A3 in urine: a highly specific noinvasive marker for prostate cancer early detection. J. Urol., v.181, p.343-53, 2009.

SELLER, M.J. et al. Confirmation of the high frequency of the TMPRSS2/ERG fusion gene in prostate SETH, A; WATSON, D.K. ETS transcription factors and their emerging roles in human cancer. Eur $J$ Cancer, v.41, p.2462-78, 2005.

SHAIKHIBRAHIM, Z. et al. The peripheral zone of the prostate is more prone to tumor development than the transitional zone: Is the ETS family the key. Mol. Med. Report, v.5, p.313-316, 2012.

SIEGEL, R. et al. Cancer statistics, 2011: the impact of eliminating socioeconomic and racial disparities on premature cancer deaths. C.ACancer J. Clin., v.61 (4), p.212-36, 2011.

SKARIN, A.T. Atlas of diagnostic oncology. Mosby-Wolfe $4^{\text {th }}$ ed., p.465-552, 2010.

SOBIN, L.H. et al. UICC TNM Classification of Malignant Tumors $6^{\text {th }}$ ed. New York: John Wiley Sons, 2002.

SOBIN, L.H.; FLEMING, I.D. TNM classification of malignant tumors, fifth edition (1997). Union Internationale Contre le Cancer the American Joint Committee on Cancer. Cancer, v.80, p.1803-4, 1997.

SOBIN, L.H.; WITTEKIND, C. H. TNM Classification of Malignant Tumours- $6^{\text {th }}$ ed., 2011. 
SOBIN, L.H E COMPTON, C.C. TNM Sétima edição: o que há de novo, o que mudou: Comunicação da União Internacional contra o câncer e American Joint Committe on Cancer. Cancer, v.116, p.5336-5339, 2010 .

SREEKUMAR, A. et al. Metabolomic profiles delineate potencial role for sarcosine in prostate cancer progression. Nature, v.457, p.910-4, 2009.

STAMATIOU, K.S. Elderly and prostate cancer screening. Urol. J., v.8 (2), p.83-7, 2011.

SU, S.L. et al. Detection of extraprostatic prostate cells utilizing reverse transcription-polymerase chain reaction.Semin. Surg. Oncol., v.18, p.17-28, 2000.

SUURINIEMI, M. et al. Confirmation of a Positive Association between Prostate Cancer Risk and a Locus at Chromosome 8q24. Cancer Epidemiol Biomarkers Prev., v.16, p.809-814, 2007.

TANG, D.G. et al. Prostate cancer stem/progenitor cells: identification, characterization, and implications. Mol. Carcinog., v.46, p.1-14, 2007.

THEODORESCU, D. Prostate cancer clinical oncology. In: Schwab M., editor. Encyclopedic Reference of Cancer. 1 st ed. vol. 720, New York: Springer Verlag., 2001.

THOMPSON, I. et al. AUA Prostate Cancer Clinical Guideline Update Panel. Guideline for the management of clinically localized prostate cancer. J. Urol., v.177, p.2106-2131, 2007.

THOMPSON, I.M. et al. Operating characteristics of prostate-especific antigen in men with an initial PSA level of $3.0 \mathrm{ng} / \mathrm{ml}$ or lower. JAMA, v.294, p.66-70, 2005.

THOMPSON, I.M. et al. Prevalence of prostate cancer among men with prostate-specific antigen level $\leq$ 4 ng per milliliter. N. Engl. Med., v.350, p.2239-46, 2004.

TOMLINS, S.A. et al. Distinct classes of chromosomal rearrangements create oncogenic ETS gene fusions in prostate cancer. Nature, v.448, p.595-599, 2007.

TOMLINS, S.A. et al. ETS gene fusions in prostate cancer from discovery to daily clinical practice. Eur. Urol., v.56, p.275-286, 2009.

TOMLINS, S.A. et al. Recurrent fusion of TMPRSS2 and ETS transcription factor genes in prostate cancer. Science, v.310, p.644-648, 2005.

TOMLINS, S.A. et al. Urine TMPRSS2:ERG fusion transcript stratifies prostate cancer risk men with elevated serum PSA. Transl. Sci. Med., v.3, p. 72-94, 2011.

TOMULEASA, C. et al. Cellular interactions in prostate cancer genesis and dissemination. Looking beyond obvious.Romanian J. Morp.Embr., v.51(3), p.427-35, 2010.

TOSOIAN, J.J. et al. Active surveillance program for prostate cancer: an update of the johns Hopkins experience. J. Clin. Oncol., v.29, p.2185-2190, 2011.

US Preventive Services Task Force. Screening for prostate cancer: US Preventive Services Task Force recommendation statement. Ann Intern. Med., v.149, p.185-191, 2008.

VAARALA, M. H. et al. Expression of transmembrane serine protease TMPRSS2 in mouse and human tissues. J Pathol., v.193, p.134-140, 2001.

VAN DER HEUL NIEUWENHUIJSEN, L. et al. Gene expression profiling of the human prostates zones. BJU Int, v.98, p.886-897, 2006.

VAN DER KWAST, T.H.; JENSTER, G. Gene expression profiling of the human prostate zones. BJU Int., v.98, p.886-97, 2006.

VENKATESWARAN, V.; FLESHNER, N.E.; KLOTZ, L.H. Modulation of cell proliferation and cell cycle regulators by vitamin $\mathrm{E}$ in human prostate carcinoma cell lines. J. Urol., v.168, p.1578-82, 2002. 
VLAEMINCK-GUILLEM, V. et al. Urinary prostate cancer 3 test: Toward the age of reason?. Urology, v.75, p.447-53, 2010.

WALKER, A.R.; WALKER, B.F. Puzzles in the causation and epidemiology of prostate cancer--a sombre outlook. S Afr Med J., v.93, p.773-774, 2003.

WALTER, L.C. et al. PSA screening among elderly men with limited life expectancies. JAMA, v.296: p.2336-42, 2006.

WANG, J. et al. Expression of variant TMPRSS2/ERG fusion messenger RNAs is associated with aggressive prostate cancer. Cancer Res., v.66, p.8347-8351, 2006.

WANG, J. et al. Pleiotropic biological activities of alternatively spliced TMPRSS2/ERG fusion gene transcripts. Cancer Res., v.68 (20), p.8516-24, 2009.

WHITMAN, E.J. et al. PCA3 score before radical prostatectomy predicts extracapsular extension and tumor volume. J. Urol., v.180, p.1975-9, 2008.

WILBERT, D.M.;GRIFFIN, J.E.; WILSON J.D. Characterization of the cytosol androgen receptor of the human prostate. J.Clin. Endocrinol.Metab., v.56, p.113-120, 1983.

WINNES, M. et al. Molecular genetic analyses of the TMPRSS2-ERG and TMPRSS2-ETV1 gene fusions in 50 cases of prostate cancer. Oncology, v.17, p.1033-1036, 2007.

XU, J. et al. A combined genomewide linkage scan of 1,233 families for prostate cancer-susceptibility genes conducted by the international consortium for prostate cancer genetics. Am J Hum Genet., v.77, p.219-229, 2005.

YATANI, R., et al. Geographic pathology of latent prostatic carcinoma. Int. J. Cancer, v.29, p.611-616, 1982.

YOSHIMOTO, M. et al. Absence of TMPRSS2:ERG fusions and PTEN losses in prostate cancer is associated with a favorable outcome. Mod. Pathol., v.21, p.1451-1460, 2008.

YU, C. et al. Prostate cancer stem cell biology. Minerva Urol. Nefrol., v.64 (1), p.19-33, 2012.

ZEEGERS, M.P.; JELLEMA A.; Ostrer H. Empiric risk of prostate carcinoma for relatives of patients with prostate carcinoma: a metaanalysis. Cancer, v.97, p.1984-903, 2003.

ZHU, Y.S.; SUN, G.H. 5 $\alpha$-reductaseisozymes in the prostate. J. Med. Sci., v.25, p.1-12, 2005.

ZIPORI, D. the nature of stem cells: state rather entity. Nat. Rev. Genet., v.5 (11), p.873-78, 2004. 